Some Middle Cenomanian (Upper Cretaceous) Acanthoceratid Ammonites from the Western Interior of the United States

U.S. GEOLOGICAL SURVEY PROFESSIONAL PAPER 1445

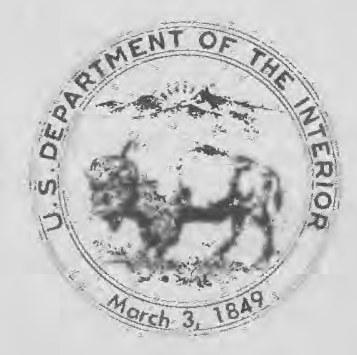




\section{Some Middle Cenomanian (Upper Cretaceous) Acanthoceratid Ammonites from the Western Interior of the United States}

By WILLIAM A. COBBAN

U. S. G E O L O G I G A L S U R V E Y P R OFE S I O N A L P P E R 1445

Ammonites of the genera

Calycoceras, Acanthoceras, Plesiacanthoceras, and Protacanthoceras from the Frontier Formation and equivalent rocks are described and illustrated

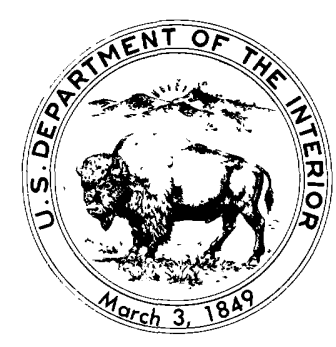




\section{DEPARTMENT OF THE INTERIOR}

DONALD PAUL HODEL, Secretary

\section{U.S. GEOLOGICAL SURVEY}

Dallas L. Peck, Director

Library of Congress Cataloging-in-Publication Data

Cobban, William Aubrey, 1916-

Some Middle Cenomanian (Upper Cretaceous) Acanthoceratid Ammonites from the Western Interior of the United States.

(U.S. Geological Survey professional paper ; 1445

Bibliography: p.

Includes index.

Supt. of Docs. no.: I 19.16:1445

1. Acanthoceratidae. 2. Paleontology-Cretaceous. 3. Paleontology-United States. I. Geological Survey (U.S.) II. Title. III. Series: Geological Survey professional paper ; 1445.

QE807.A5C625 $1987 \quad 564^{\prime} .53 \quad 86-600103$

For sale by the

Books and Open-File Reports Section

U.S. Geological Survey

Federal Center

Box 25425

Denver, CO 80225 


\section{CONTENTS}

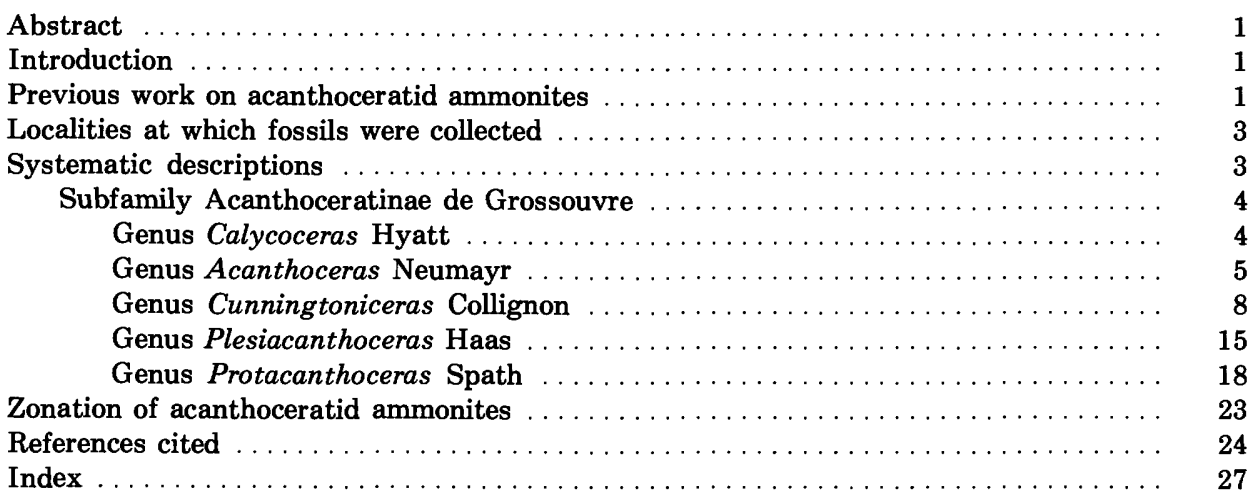

\section{ILLUSTRATIONS}

[Plates follow index]

Plate 1. Calycoceras and Acanthoceras

2. Acanthoceras

3. Protacanthoceras and Acanthoceras

4-8. Cunningtoniceras

9. Protacanthoceras and Cunningtoniceras

10. Protacanthoceras and Plesiacanthoceras

11-13. Plesiacanthoceras

Figure 1. Map of part of Western Interior showing localities of fossil collections

2. Suture of Calycoceras (Gentoniceras) leonense (Adkins) ............

3. Scatter diagram of umbilical ratios of Acanthoceras bellense Adkins .

4. Histogram of diameters at base of body chambers of Acanthoceras bellense

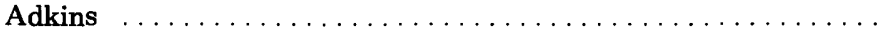

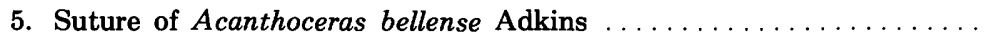

6. Scatter diagram of ribs per half whorl of Acanthoceras muldoonense Cob-

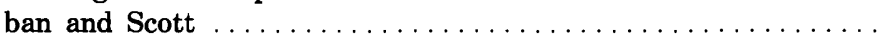

7. Map showing localities of Cunningtoniceras amphibolum (Morrow) ...

8. Scatter diagram of umbilical ratios of Cunningtoniceras amphibolum amphibolum (Morrow) and C. amphibolum fallense Cobban, n. subsp

9. Histogram of diameters at base of body chambers of Cunningtoniceras am-

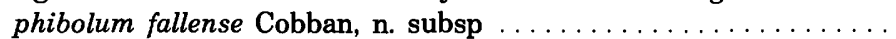

10. Map of Wyoming showing localities of Plesiacanthoceras wyomingense

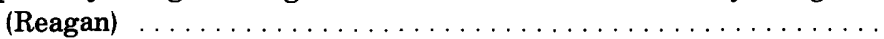

11. Histogram of diameters at base of body chambers of Protacanthoceras hosei

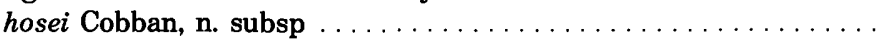

12. Suture of Protacanthoceras hosei hosei Cobban, n. subsp .........

13. Histogram of diameters at base of body chambers of Protacanthoceras hosei

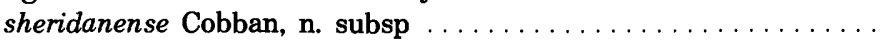

14. Suture of Protacanthoceras hosei sheridanense Cobban, n. subsp ....

15. Histogram of diameters at base of body chambers of Protacanthoceras

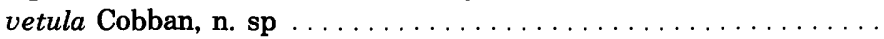

Page

2

5

6

7

7

8

10

14

15

17

19

19

20

20

21 
FIGURE 16. Suture of Protacanthoceras vetula Cobban, n. sp .............. Page 21

17. Histogram of diameters at base of body chambers of Protacanthoceras alzadense Cobban, $n$. sp ........................... 22

18. Suture of Protacanthoceras alzadense Cobban, $n$. sp ........... 22

19. Suture of Protacanthoceras fisherense Cobban, n. sp ............. 23 


\title{
SOME MIDDLE CENOMANIAN (UPPER CRETACEOUS) ACANTHOGERATID AMMONITES FROM THE WESTERN INTERIOR OF THE UNITED STATES
}

\author{
By William A. CobBaN
}

\begin{abstract}
The ammonite family Acanthoceratidae de Grossouvre is represented in the Western Interior region by many genera. Species and subspecies of Calycoceras, Acanthoceras, Cunningtoniceras, Plesiacanthoceras, and Protacanthoceras are important guide fossils to narrow zones of middle Cenomanian age in southeastern Montana, northeastern Wyoming, western South Dakota, and central Kansas. In this region, the ammonite zonation through most of the middle Cenomanian seems to be, from oldest to youngest, a zone of Acanthoceras muldoonense Cobban and Scott, a zone of Acanthoceras bellense Adkins and Calycoceras leonense (Adkins), a zone of Cunningtoniceras amphibolum (Morrow) with subzones of C. amphibolum amphibolum and C. amphibolum fallense (n. subsp.), and a zone of Plesiacanthoceras wyomingense (Reagan).

In this report, Acanthoceras muldoonense, A. bellense, and Calycoceras leonense are described from the northern part of the Western Interior for the first time. Cunningtoniceras amphibolum, originally assigned to Acanthoceras, is described in more detail and divided into the nominate subspecies and the new subspecies C. amphibolum fallense. The earliest whorls of Plesiacanthoceras wyomingense, previously unknown, are described as well as all the later growth stages. The small genus, Protacanthoceras, is represented by several new species and one new subspecies. Protacanthoceras fisheri is found in the zone of Acanthoceras bellense, $P$. vetula occurs in the subzone of Cunningtoniceras amphibolum amphibolum, and $P$. hosei hosei and $P$. hosei sheridanense are found in the subzone of $C$. amphibolum fallense. Protacanthoceras alzadense is associated with Plesiacanthoceras wyomingense.
\end{abstract}

\section{INTRODUCTION}

The family Acanthoceratidae de Grossouvre (1894) includes ammonites that have strong ornament of umbilical and ventrolateral tubercles and, in many genera, midventral (siphonal) tubercles as well. Ribs are usually conspicuous at some growth stage and can be the dominant ornament. The family ranges from the lower Cenomanian to the Coniacian and has a worldwide distribution. Acanthoceratid ammonites were the dominant forms in the Cenomanian of many parts of the world.
Most genera of ammonites of Cenomanian and Turonian age in the Western Interior belong to the Acanthoceratidae. Specimens are abundant in places, especially in silty limestone concretions in the Frontier Formation of Wyoming and southern Montana and in limestone concretions in the Belle Fourche Shale around the flanks of the Black Hills. Specimens in the limestone concretions are usually uncrushed, and many retain part or much of their shell material, which has generally been converted to calcite. At a few localities, nacreous aragonitic shell material has been retained.

Many of the species have been poorly known because of brief descriptions and lack of enough illustrations to show growth stages and variation in form and ornament. Other species have been undescribed. The present report was undertaken to more firmly define a few of the earlier named species, and to describe some of the new forms.

All specimens described in this report are kept in the National Museum of Natural History (USNM) in Washington, D.C., and have USNM catalog numbers. Plaster casts of the holotypes are in the U.S. Geological Survey's reference collections at the Federal Center, Denver, Colo. Robert E. Burkholder, of the U.S. Geological Survey, made all the photographs. The author made the drawings of sutures.

\section{PREVIOUS WORK ON ACANTHOCERATID AMMONITES}

Ammonites of the family Acanthoceratidae were not recorded from the Western Interior of the United States until 1877, when White $(1877$, p. 201, 202) described the new species Ammonites loevianus from New Mexico and figured specimens from Utah that he assigned to Buchiceras swallovi (Shumard). Later in that century, Stanton (1893) described the new species Acanthoceras 


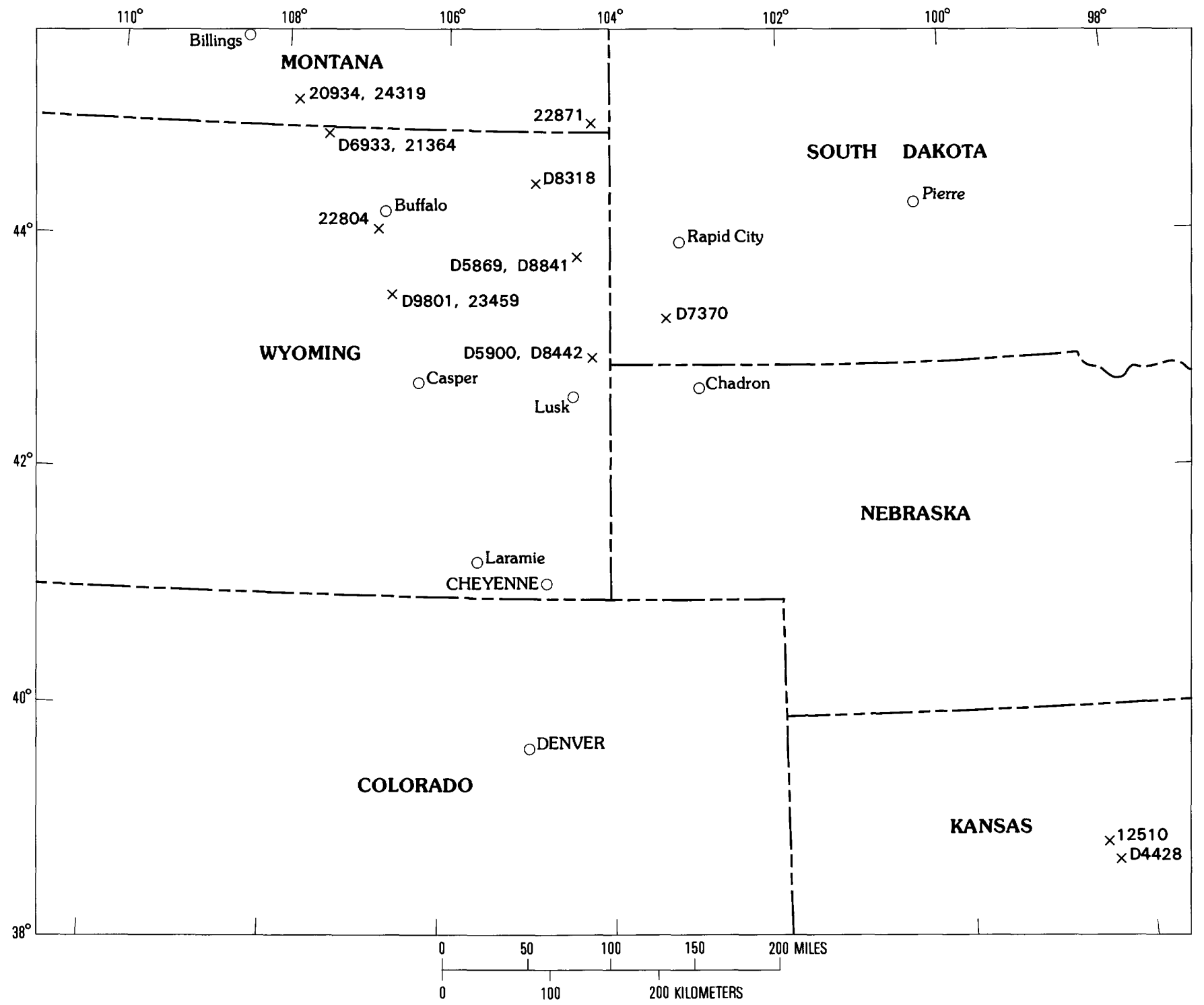

FIGURE 1.-Map of part of the Western Interior of the United States showing localities of fossil collections. Numbers are U.S. Geological Survey Mesozoic localities.

kanabense. In the early part of the next century, Hyatt (1903) described as new Metoicoceras whitei and $M$. kanabense from Utah, and Henderson (1908) described the new species Acanthoceras coloradoensis from Colorado. Acanthoceratids had not been noted north of Colorado until Reagan (1924) described a species from the Frontier Formation of Wyoming that he named Metoicoceras wyomingensis. A little later Reeside (1927) recorded, but did not illustrate, an acanthoceratid fauna from Colorado. An important paper was that by Morrow (1935), who described the new species Acanthoceras amphibolum, Mammites wingi, $M$. rectangulus, and Pseudaspidoceras cornucostale from the Graneros Shale and Greenhorn Limestone of central
Kansas. Haas $(1949,1951,1963,1964)$ contributed much to our knowledge of the acanthoceratids of the Frontier Formation of Wyoming in describing the new species and subspecies Mantelliceras canitaurinum, Metoicoceras whitei praecox, Dunveganoceras pondi, and $D$. conditum, and in erecting the new genus Plesiacanthoceras. Acanthoceratid ammonites from farther north, in central Montana, were treated by me (Cobban, 1953), and included the new species and subspecies Metoicoceras mosbyense, $M$. muelleri, Dunveganoceras albertense montanense, and $D$. parvum. A new species, Paracompsoceras landisi, and many splendid examples of Calycoceras naviculare (Mantell), from the Greenhorn Limestone of Colorado, were also described by me 
(Cobban, 1971). The largest work that includes many acanthoceratid ammonites was on the ammonites from the Graneros Shale and Greenhorn Limestone of the Pueblo area of Colorado (Cobban and Scott, 1972). New species described were Calycoceras (Conlinoceras) gilberti, Acanthoceras muldoonense, A. granerosense, Kanabiceras puebloense, and Ampakabites collignoni. Many previously named species of Calycoceras, Pseudocalycoceras, Tarrantoceras, Acanthoceras, Euomphaloceras, Kanabiceras, Metoicoceras, Watinoceras, and Mammites were described and illustrated in that paper. The most recent work concerning acanthoceratid ammonites is that of Cobban and Hook (1983a) in which the new genus Morrowites was proposed and the new species $M$. subdepressus was described. Illustrations of some of the earlier named species can be found in many papers (Cobban, 1971, 1975, 1977, 1983, 1984b, Cobban and Hook, 1979, 1983a, 1983b; Hook and Cobban, 1981, 1982; Hattin, 1965a, 1965b, 1968, 1975, 1977; Hattin and Siemers, 1978; Kauffman, 1977; Kauffman and others, 1976; Kauffman and Powell, 1977; Merewether and others, 1979).

\section{LOCALITIES AT WHICH FOSSILS WERE COLLECTED}

The ammonites described or reported on in this report came mainly from 17 localities in southern Montana, the northeast quarter of Wyoming, southwestern South Dakota, and central Kansas (fig. 1). The U.S. Geological Survey Mesozoic locality number, names of collectors, year of collection, locality, and stratigraphic position are as follows (prefix D indicates Denver Mesozoic locality numbers; the rest are Washington, D.C., Mesozoic locality numbers):

\section{Locality}

number

$$
\text { Locality }
$$

D4428. W. A. Cobban, 1964. Beside road in the NW1/4 sec. 3, T. 16 S., R. 10 W., Ellsworth County, Kans. Graneros Shale, from brown calcarenitic limestone $3.4 \mathrm{~m}(11 \mathrm{ft})$ below the bentonite marker bed near the top.

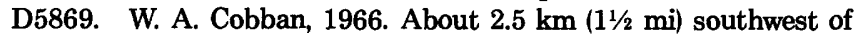
Osage near the center of sec. 17, T. 46 N., R. 63 W., Weston County, Wyo. Belle Fourche Shale, from a gray calcareous concretion $33.8 \mathrm{~m}(111 \mathrm{ft})$ below a $0.6-\mathrm{m}$-thick bed of bentonite.

D5900. W. A. Cobban, 1967. Head of Elm Creek in W1/2 sec. 14, T. 36 N., R. 62 W., Niobrara County, Wyo. Belle Fourche Shale, from limestone concretions $3.6 \mathrm{~m}(12 \mathrm{ft})$ below bentonite marker bed.

D6933. W. A. Cobban, 1969. North of Gay Creek in the SE1/4 sec. 18, T. 58 N., R. 88 W., Sheridan County, Wyo. Frontier Formation, from limestone concretions developed along the Soap Creek Bentonite Bed.

D7370. W. A. Cobban, 1970. About $6.7 \mathrm{~km}$ (4 mi) southeast of Hot Springs in the NE $1 / 4$ sec. 34, T. 7 S., R. 6 E., Fall River County, S. Dak. Belle Fourche Shale, from limestone concretions at top of bentonite marker bed.
Locality

number

Locality

D8318. E. A. Merewether, 1971. SW $1 / 4$ sec. 22, T. 52 N., R. 67 W., Crook County, Wyo. Belle Fourche Shale, from limestone concretions at base of bentonite marker bed.

D8442. E. A. Merewether, 1972. NW1/4 sec. 35, T. 37 N., R. 62 W., Niobrara County, Wyo. Belle Fourche Shale, from limestone concretions at base of bentonite marker bed.

D8841. W. A. Cobban, 1966. About $2.8 \mathrm{~km} \mathrm{(13/4} \mathrm{mi)} \mathrm{west} \mathrm{of} \mathrm{Osage}$ in the SW1/4 sec. 8, T. 46 N., R. 63 W., Weston County, Wyo. Belle Fourche Shale, from a gray calcareous concretion at same stratigraphic position as D5869.

D9801. E. A. Merewether, 1975. South of Lone Bear road in the SW1/4 sec. 13, T. 42 N., R. 82 W., Johnson County, Wyo. Frontier Formation, from dusky-red ferruginous concretions about same stratigraphic position as locality 23459 .

12510. N. W. Bass, W. W. Rubey, and J. B. Reeside, Jr., 1924. Bank of Smoky Hill River $4 \mathrm{~km}\left(2 \frac{1}{2} \mathrm{mi}\right)$ south of Wilson, Ellsworth County, Kans. Graneros Shale, from limestone

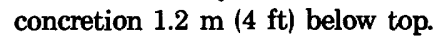

20934. W. A. Cobban, 1947. East flank of Soap Creek dome and $4.5 \mathrm{~km}(2.8 \mathrm{mi})$ east of West Fork of Soap Creek in the $\mathrm{SE}^{1 / 4} \mathrm{sec}$ 35, T. 6 S., R. 32 E., Big Horn County, Mont. Upper part of Belle Fourche Member of Cody Shale, from silty concretions just below Soap Creek Bentonite Bed.

21364. W. A. Cobban, 1947. From bentonite pit in the SW $1 / 4 \mathrm{sec}$. 17, T. 58 N., R. 88 W., Sheridan County, Wyo. Frontier Formation, from limestone concretions developed along the Soap Creek Bentonite Bed.

22804. R. K. Hose and Theodore Scott, 1950 . Dry Muddy Creek in center of sec. 1, T. 48 N., R. 83 W., Johnson County, Wyo. Frontier Formation, from brown-weathering septarian very fine grained sandstone concretions $38 \mathrm{~m}$ (125 $\mathrm{ft}$ ) below top.

22871. J. B. Reeside, Jr., C. T. Moore, and W. A. Cobban, 1949. About $9.6 \mathrm{~km}(6 \mathrm{mi})$ northeast of Alzada in the $\mathrm{SE}^{1 / 4} \mathrm{sec} .6$, T. 9 S., R. 59 E., Carter County, Mont. Belle Fourche Shale, from light-gray-weathering limestone concretions in upper part.

23459. W. A. Cobban, 1959; Cobban, J. R. Gill, and R. T. Fleisher, 1966. Near head of Fisher Draw about $4.5 \mathrm{~km}(2.7 \mathrm{mi})$ south of Kaycee in sec. 25, T. 43 N., R. 82 W., Johnson County, Wyo. Frontier Formation, from concretions of

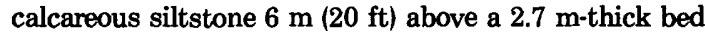
of bentonite.

24319. W. A. Cobban, 1947. NW1/4 sec. 31, T. 7 S., R. 33 E., Big Horn County, Mont. Frontier Formation, float on Soap Creek Bentonite Bed.

\section{SYSTEMATIC DESCRIPTIONS}

In the descriptions, umbilical diameters are usually given as ratios to the shell diameters. In the drawings of sutures, the heavy straight line marks the middle of the venter as well as the middle of the external lobe. The umbilical shoulder is indicated by the curved dashed line, and the umbilical seam is marked by the smaller curved solid line. Only the major sutural elements are identified; E stands for the external lobe, $L$ stands for the lateral lobe, and E/L stands for the saddle that separates these lobes. 


\section{Phylum MOLLUSCA \\ Class CEPHALOPODA \\ Order AMMONOIDEA \\ Suborder AMMONITINA \\ Superfamily ACANTHOCERATACEAE de Grossouvre, 1893 [1894] \\ Family ACANTHOCERATIDAE de Grossouvre, 1893 [1894] Subfamily ACANTHOCERATINAE de Grossouvre, 1893 [1894] \\ Genus CALYCOCERAS Hyatt, 1900}

Calycoceras (Gentoniceras) leonense (Adkins)

Plate 1, figures 1-17; text figure 2

1928. Eucalycoceras leonense Adkins, University of Texas Bulletin 2838 , p. 240 , pl. 28 , fig. 1 ; pl. 29 , fig. 3 .

1928. Metacalycoceras? sp. 2. Adkins, University of Texas Bulletin 2838 , p. 242 , pl. 28 , fig. 2 ; pl. 29 , fig. 2 .

1942. Eucalycoceras leonense Adkins. Moreman, Journal of Paleon tology, v. 16, no. 2, p. 207.

1969. Eucalycoceras (Proeucalycoceras) leonense Adkins. Thomel, Academie des Sciences [Paris], Comptes Rendus Hebdomadaires des Scances, Series D, Sciences Naturelles, v. 268, no 4 , p. 650.

1972. Eucalycoceras (Proeucalycoceras) leonense Adkins. Thomel, Mémoires de la Société Géologique de France, n. ser., v. 51, Mémoire 116, p. 81.

1972. Calycoceras leonense (Adkins). Cobban and Scott, U.S. Geological Survey Professional Paper 645, p. 60, pl. 3, figs. $1-4$.

This species is characterized by its sparse ribbing and by the persistence of tuberculation well on to the adult body chamber. The species is small for the genus.

The holotype came from the basal part of the Eagle Ford Group (Upper Cretaceous) in Bell County in eastcentral Texas. Adkins (1928, p. 240) did not give its diameter, but a plaster cast suggests a diameter of about $46 \mathrm{~mm}$ and an umbilical ratio of 0.28 . The specimen consists of most of an outer whorl; inner whorls are not exposed. Whorl section is stout and about as broad as high. Flanks are very broadly rounded and merge evenly into the more narrowly rounded venter. The umbilical shoulder is narrowly rounded, and the umbilical wall is steep. Ribs, which alternate in length, are narrow, rounded, straight, and rectiradiate; all cross the venter transversely and strongly. Primary ribs begin at the umbilical seam and rise into conspicuous bullae on the umbilical shoulder. Secondary ribs arise on the inner third of the flank and, on crossing the venter, are as strong as the primaries. All ribs support small inner and outer ventrolateral and siphonal tubercles. Inner ventrolateral tubercles weaken and disappear on the younger half of the whorl. The last half whorl has 15 ribs of which 8 are primaries that bear umbilical bullae. From the type locality of $C$. leonense, Adkins (1928, p. 242, pl. 28, fig. 2; pl. 29, fig. 2) figured another ammonite as Metacalycoceras? sp. 2. This specimen, which is poorly preserved, consists of half a whorl about $66 \mathrm{~mm}$ in diameter. Ribs are narrow, rectiradiate, and alternate in length; they number 14 . The specimen is probably a fragment of a large $C$. leonense as previously suggested (Cobban and Scott, 1972, p. 60).

The late L. W. Stephenson, formerly of the U.S. Geological Survey, made two collections of $C$. leonense from the type locality in Bell County, Tex. These collections (USGS Mesozoic locs. 11845 and 13577) have 22 specimens suitable for the determination of one or more of the following measurements: umbilical ratio, diameter at base of the body chamber, and number of ribs in half a whorl. Umbilical ratios range from 0.27 to 0.37 and show a gradual increase with growth. Ribs per half whorl range from 12 to 17 , averaging 14. Diameters at the base of body chambers could be determined for 13 of the specimens. These diameters range from 30 to $58 \mathrm{~mm}$, with most in the 36-46 range. Dimorphism cannot be demonstrated with the material at hand.

Ammonites that seem referable to $C$. leonense occur at few localities in the Western Interior region. The largest collection is from a limestone concretion in the Belle Fourche Shale at locality D8841 near Osage, Wyo., on the west flank of the Black Hills uplift (fig. 1). Twentyeight of the specimens from this concretion are suitable for rib counts and for the determination of either the umbilical ratio or the diameter at the base of the body chamber or both. The specimens range in diameter from 23 to $72 \mathrm{~mm}$. Umbilical ratios range from 0.25 to 0.38 , and show a slight increase with growth.

The smallest entire whorl examined from locality D8841 has a diameter of $23 \mathrm{~mm}$ and an umbilical ratio of 0.29 (pl. 1, figs. 3-5). Ornament, which is well developed on this whorl, consists of 23 narrow primary and secondary ribs, umbilical bullae, inner and outer ventrolateral tubercles, and siphonal tubercles. Ribs arch forward a little on crossing the venter on the older part of the whorl, but on the younger part, the ribs cross the venter more transversely. Ventrolateral and siphonal tubercles are nodate and about equal in size on the older part of the whorl, but on the younger part, the outer ventrolateral and siphonal tubercles become somewhat clavate and a little larger than the nodate inner ventrolateral ones. A smaller whorl, only partly exposed, has equal-sized clavate outer ventrolateral and siphonal tubercles and pointed, nodate inner ones all well developed at a diameter of about $7 \mathrm{~mm}$ (pl. 1, figs. 6, 7). Inner ventrolateral tubercles weaken and disappear on the larger shells at some diameter from 25 to $32 \mathrm{~mm}$. The outer ones and the siphonal tubercles persist on to the older part of the adult body chamber before weakening and disappearing. Ribs remain narrow and conspicuous to the adult aperture. Most are rectiradiate and straight to slightly flexuous. An occasional specimen may have some rursiradiate ribbing (pl. 1, fig. 12) or some 
prorsiradiate ribbing (pl. 1, fig. 15). Ribs number 12-17 per half whorl, averaging 12.

Body chambers occupy about half a whorl. Diameters at the base of body chambers could be either measured or estimated for 20 specimens from locality D8841 near Osage. These diameters ranged from $26.5 \mathrm{~mm}$ to $51.0 \mathrm{~mm}$, with most in the $32-44 \mathrm{~mm}$ range. Clustering of diameters into two dimorphic groups could not be demonstrated with the material at hand. The largest complete adult in the collection (hypotype USNM 388091 ) has a diameter of $72 \mathrm{~mm}$ and an umbilical ratio of 0.38 (pl. 1, figs. 12, 13). Diameter at the base of its body chamber is $51 \mathrm{~mm}$. An occasional fragment in the collection indicates still larger specimens (pl. 1, figs. 16, 17).

The suture of the holotype is not preserved. An external suture of one of the specimens from locality D8841 is shown in figure 2. The lateral lobe $(\mathrm{L})$ is short, and the $\mathrm{E} / \mathrm{L}$ saddle is very broad and shallow.

The specimens from Osage (loc. D8841) are assigned to $C$. leonense, although they differ a little from the collections from Bird Creek (locs. 11845 and 13577). The Osage specimens tend to be slightly more evolute (average umbilical ratio of 0.33 compared to 0.31 ) and a little more sparsely ribbed (average half whorl rib count of 12 compared to 14.5). These differences may be due to the great distance of $1,560 \mathrm{~km}(970 \mathrm{mi})$ that separates the Osage and Bird Creek localities, or possibly the localities may not be the same age. In their sparse ribbing and in the size of their umbilici, the Osage specimens resemble an ammonite from the Woodbine Formation (Upper Cretaceous) of Texas that was identified as Acanthoceras barcusi Jones by Stephenson (1952, p. 203, pl. 44, figs. 9-11). The Woodbine specimen differs mainly in having thicker ribs and in retaining tuberculation to a larger diameter. The holotype of $A$. barcusi (Jones, 1938, p. 117, pl. 6, figs. $2,3,8,9$ ) is a larger and more robust shell $83 \mathrm{~mm}$ in diameter that retains tuberculation to a much greater diameter than on any specimens from Osage. Jones' holotype and

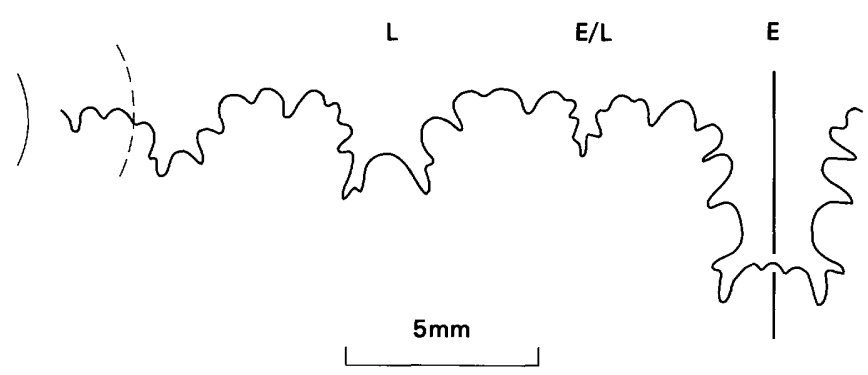

Figure 2.-Last external suture of Calycoceras (Gentoniceras) leonense (Adkins) at a diameter of $34 \mathrm{~mm}$ from the Belle Fourche Shale at locality D8841 (fig. 1). Hypotype USNM 388087.
Stephenson's specimen seem better assigned to Calycoceras because of their rounded whorls and ribs of alternate lengths.

Fossils associated with C. leonense at locality D8841 include Acanthoceras bellense Adkins, Borissiakoceras orbiculatum Stephenson, Inoceramus arvanus Stephenson, and Drepanochilus sp.

Types-Hypotypes USNM 388087-388093.

\section{Genus ACANTHOCERAS Neumayr, 1875} Acanthoceras bellense Adkins

Plate 1, figures 18, 19; plate 2; text figure 5

1928. Acanthoceras bellense Adkins, University of Texas Bulletin 2838 , p. 245 , pl. 30 , figs. $1,2$.

1942. Acanthoceras bellense Adkins. Moreman, Journal of Paleontology, v. 16, no. 2, p. 203.

Acanthoceras bellense is a moderate-sized species that is characterized by its conspicuous tuberculated phragmocone and by its sparsely ribbed body chamber.

The holotype came from the basal part of the Eagle Ford Group of east-central Texas. Adkins did not give its size, but a plaster cast indicates a diameter of about $91 \mathrm{~mm}$. The type is an undeformed phragmocone that is badly corroded on one side as well as on much of the opposite side and on the older half of the venter (pl. 1, figs. 18, 19). Much of the cross section of the outer whorl is rather rounded and about as high as wide, but near the larger end, the section becomes more subquadrangular with very broadly rounded flanks and venter and more narrowly rounded ventrolateral shoulder. The umbilicus, which has a ratio of 0.26 , has a well-rounded shoulder that merges evenly into the rounded, sloping wall. Ornament on the outer whorl consists of low, narrow ribs; weak umbilical bullae; stronger inner and outer ventrolateral tubercles; and very weak siphonal clavi on a low, rounded siphonal ridge. Details of the ornament on the older half of the outer whorl cannot be determined owing to the eroded condition. Ribs on the younger half of the whorl are mostly of equal strength, rectiradiate, and very slightly flexuous. A few raised striae separate some of the ribs. Ribs begin at the umbilical seam, rise into low umbilical bullae on the lower part of the flank, and rise again into equal-sized nodate inner ventrolateral tubercles and clavate outer ones. These tubercles are matched by weak, clavate siphonal tubercles located directly across the venter. Adkins noted that only parts of the suture were visible.

The holotype came from hard calcarenitic limestone that was originally assigned to the Flag Member of the Eagle Ford (Adkins, 1928, p. 246), later to the Tarrant Formation (Moreman, 1942, p. 204), and more recently to the Bluebonnet Member of the Lake Waco Formation (Adkins and Lozo, 1951, p. 130). Ammonites 
associated with the holotype were described by Adkins (1928) as the new species Acanthoceras lonsdalei, A. stephensoni, and Eucalycoceras leonense. At a later date, Moreman (1942) described A. validum and A. pepperense as additional new species from the type locality of $A$. bellense.

Ammonites that seem assignable to $A$. bellense have been found in only one small area in the Western Interior of the United States. This area, in the Osage oil field on the west flank of the Black Hills uplift in western Wyoming, has two localities of $A$. bellense $1.4 \mathrm{~km}$ apart (fig. 1, locs. D5869, D8841). The larger collection (D8841) contains 84 specimens suitable for the determination of one or more of the following measurements: umbilical ratio, diameter at the base of the body chamber, and the number of umbilical and ventrolateral tubercles per half whorl. Phragmocones are well preserved, but body chambers are crushed.

The smallest whorls examined from locality D8841 have diameters of slightly less than $10 \mathrm{~mm}$ (pl. 2, figs. $9-11,24,25)$. At these diameters, whorls are subquadrate and wider than high with flattened flanks and very broadly rounded venter. Ornament is well established and consists of low rectiradiate ribs that support weak umbilical bullae, pointed inner ventrolateral tubercles, somewhat clavate outer ones, and clavate siphonal tubercles. One individual (hypotype USNM 388097 ) seems to have a weak constriction that crosses the venter transversely at a diameter of about $5 \mathrm{~mm}$ (pl. 2, fig. 11). At a diameter of $9.8 \mathrm{~mm}$, this specimen has 13 ventrolateral tubercles per whorl. As the shell enlarges, the whorl section becomes slightly more quadrate, although all whorls seem to be a little wider than high with the greatest width at the umbilical shoulder (pl. 2, figs. 1-8). Umbilical ratios range from 18 to 29 percent of the diameter in the $20-70 \mathrm{~mm}$ size group, and from 23 to 28 percent at larger diameters (fig. 3). Umbilical bullae, ventrolateral tubercles, and siphonal clavi persist to the end of the adult phragmocone.
Ventrolateral tubercles number 8 to 12 per half whorl at diameters of $10-40 \mathrm{~mm}, 7-11$ at diameters of $40-50$ $\mathrm{mm}$, and 6-9 at larger diameters. All ornament on the adult body chamber weakens except for the umbilical bullae and the inner ventrolateral tubercles (pl. 2, figs. $28,29)$. The latter enlarge into short, stout outward directed horns. On some individuals, the outer ventrolateral tubercles and the siphonal ones disappear on the body chambers. On others, a low siphonal ridge may persist on the body chambers. An occasional very weak, nontuberculate rib may lie on the venter between two tuberculate ribs. These rare secondary ribs were not observed on specimens of less than $33 \mathrm{~mm}$ diameter. None of the adult specimens has the aperture completely preserved. One crushed specimen, (unfigured hypotype USNM 388107), about $97 \mathrm{~mm}$ in diameter, has a nearly complete body chamber that occupies a third of a whorl. Ornament on the flank of this body chamber consists of four umbilical bullae located well out on the flank and a final flange-like, fairly narrow, rectiradiate rib that supports an umbilical bulla. The first three umbilical bullae are matched by large, thick, clavate inner ventrolateral tubercles, weak outer ventrolateral clavi, and weak siphonal clavi. These tubercles disappear abruptly, and the fourth umbilical bulla is matched by a fairly broad, transverse ventral rib that is thickened and accentuated a little on the ventrolateral shoulder. The terminal flange is broken off on the venter, but on a fragment of another body chamber (unfigured hypotype USNM 388108), the flange rises high above the venter.

The specimens of $A$. bellense from locality D8841 are dimorphic. Diameters at the base of body chambers could be measured or estimated for 52 specimens. These measurements revealed a grouping in the $30-62 \mathrm{~mm}$ range and in the 74-88 $\mathrm{mm}$ range (fig. 4). Most measurements are in the smaller size range, but these are due to the better preservation of the smaller specimens. There are many fragments of body chambers of

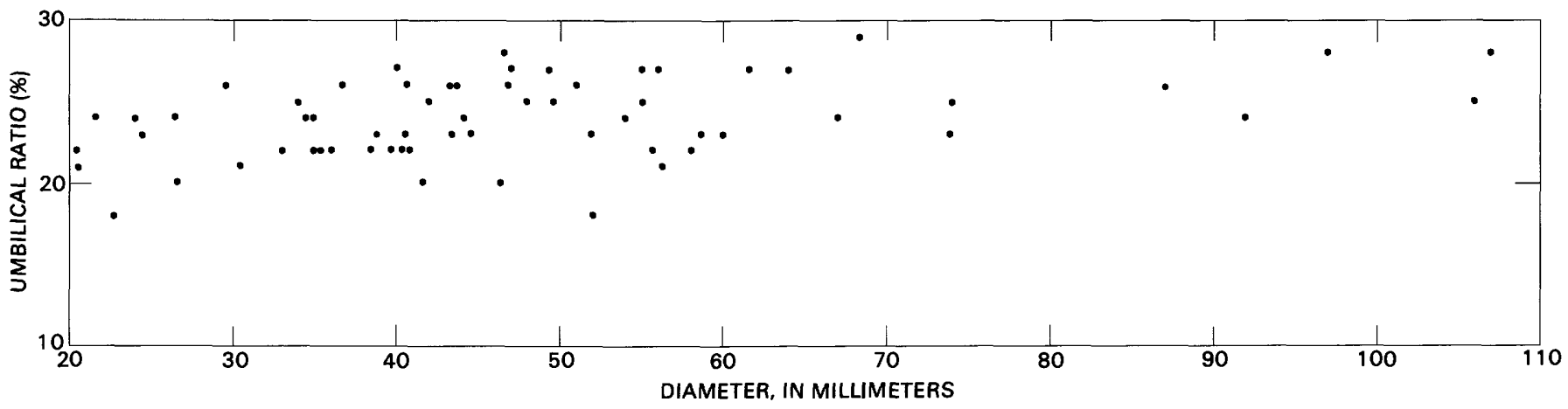

Figure 3.-Scatter diagram showing umbilical ratios of 62 specimens of Acanthoceras bellense Adkins from the Belle Fourche Shale at locality D8841 (fig. 1). 


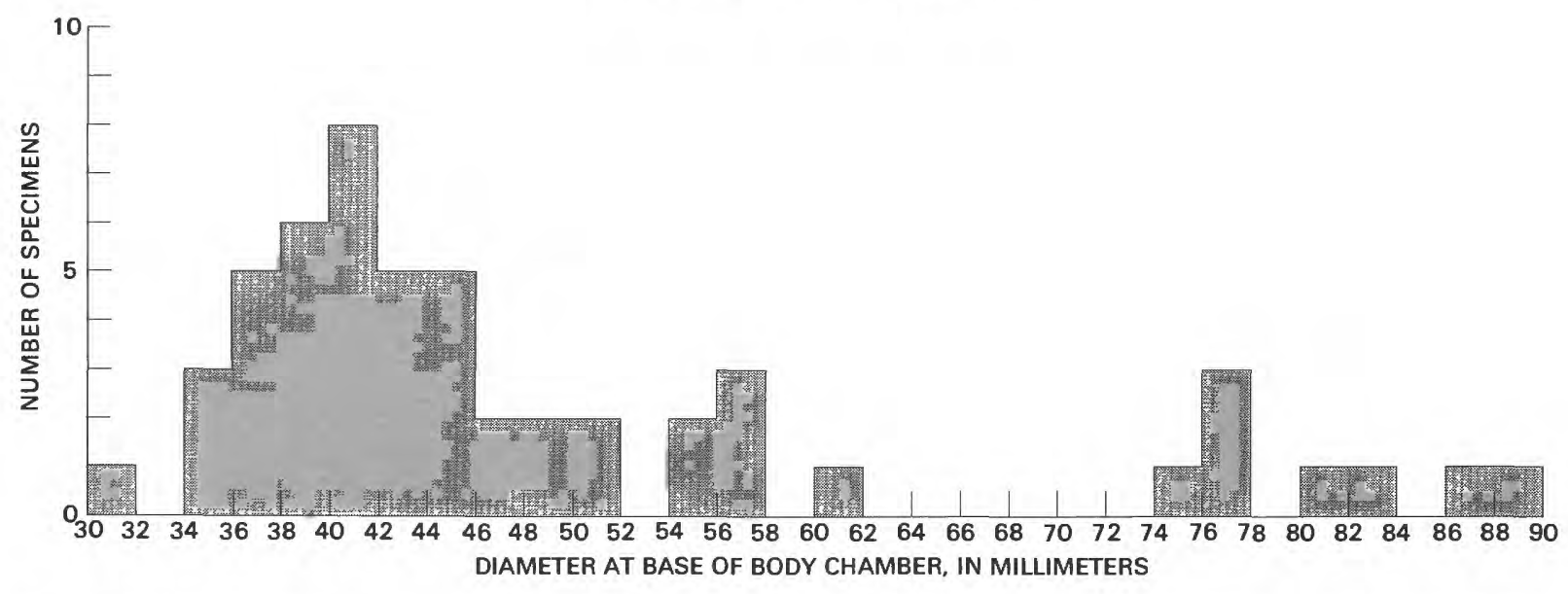

FIGURE 4.-Histogram showing diameters at base of body chambers of the 53 measurable specimens of Acanthoceras bellense Adkins from the Belle Fourche Shale at locality D8841 (fig. 1).

specimens that would fall in the 74-88 $\mathrm{mm}$ range, but these lack attached phragmocones necessary for diameter measurements.

Although most specimens resemble the bulk of those shown on plate 2, there are some unusual variants. An occasional individual may have the ventrolateral tubercles raised a little above the venter, and in this manner, it shows some resemblance to $A$. muldoonense. An unusual specimen is part of a small phragmocone that is well ornamented on the older part and nearly smooth on the younger part (pl. 2, fig. 18).

Adkins (1928, p. 245) gave only a brief description of part of the external suture of $A$. bellense without an illustration. The complete external suture of a hypotype (USNM 388109) from locality D8841 is shown in figure

5. The suture is typical of the genus.

Fossils associated with Acanthoceras bellense at localities D5869 and D8841 include the ammonites Calycoceras (Gentoniceras) leonense (Adkins) and Borissiakoceras orbiculatum Stephenson, the bivalve Inoceramus arvanus Stephenson, and the gastropod Drepanochilus sp.

Types.-Hypotypes USNM 388094-388109.

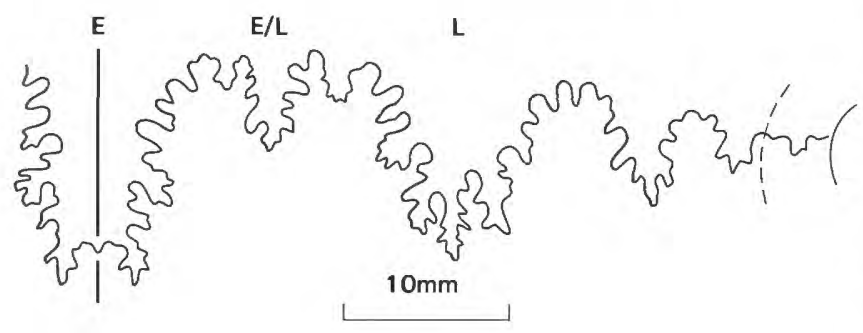

Figure 5.-External suture of Acanthoceras bellense (Adkins) at a whorl height of $25.7 \mathrm{~mm}$ from the Belle Fourche Shale at locality D8841 (fig. 1). Hypotype USNM 388109.

\section{Acanthoceras muldoonense Cobban and Scott}

Plate 3, figures 7-34

1972.

Acanthoceras muldoonense Cobban and Scott, U.S. Geological Survey Professional Paper 645, p. 67, pl. 4, figs. 1, 3; pl. 7, figs. 1-13; pl. 11, figs. 12, 13; text figs. $27,28$.

This species is characterized by sparse ribbing on adults, by early loss of siphonal and outer ventrolateral tubercles, and by the development of the inner ventrolateral tubercles into upward projected horns on the outer whorl. The species was based on fragments of internal molds from ferruginous concretions in the upper part of the Graneros Shale of south-central Colorado.

The holotype (USNM 163941) is a small crushed adult that has a diameter of $143 \mathrm{~mm}$ and an umbilical ratio of 0.25 . Most of the body chamber and the last two septate whorls are preserved. Diameter at the base of the body chamber is about $88 \mathrm{~mm}$. The body chamber consists of a little more than half a whorl ornamented by weak ribs of equal length that support umbilical bullae well out on the flank and clavate ventrolateral horns. There are seven umbilical bullae and eight ventrolateral horns in half a whorl.

The smallest specimen in the type lot has a diameter of $12.5 \mathrm{~mm}$. Fragments of the largest specimens in the type lot suggest that $A$. muldoonense attained diameters as much as $200 \mathrm{~mm}$.

Sutures are not preserved on the holotype. The external suture of a paratype (Cobban and Scott, 1972, text fig. 28) is typical of Acanthoceras in its general appearance; it has a broad, bifid E/L saddle and narrower, bifid, rectangular $\mathrm{L}$.

Specimens of Acanthoceras muldoonense from the Frontier Formation of north-central Wyoming are preserved better than those from the type area in Colorado. The largest collection from the Frontier is from 
concretions of calcareous siltstone at locality 23459 near Kaycee (fig. 1). Here 42 specimens, mostly $8-40 \mathrm{~mm}$ in diameter, were collected that are suitable for measurements of diameter, umbilicus, and number of umbilical and ventrolateral tubercles in half a whorl. At the smallest diameter observed, $3.7 \mathrm{~mm}$, whorls are smooth and broader than high with broadly rounded venter and flanks. Ornament, in the form of weak transverse ventral ribs, first appears at some diameter between 4.5 and $6.3 \mathrm{~mm}$. Within half a whorl of the appearance of ribbing, nodate siphonal and outer ventrolateral tubercles form on the ribs. By a diameter of 11 or $12 \mathrm{~mm}$, the flanks become flattened and bordered by a row of weak, nodate inner ventrolateral tubercles. At this diameter, ribs have become stronger and forwardly arched a little as they cross the venter. Every other rib tends to be longer and extends to the umbilical wall. By a diameter of 15-20 mm, whorls are about as high as wide with flattened flanks and venter. Ribs become transverse on crossing the venter, and the siphonal and outer ventrolateral tubercles become somewhat clavate. Umbilical bullae may appear on the longer ribs of some specimens. Inner ventrolateral tubercles, which are nodate and smaller than the outer ones, are located on the upper part of the flank. As the shell enlarges, the inner ventrolateral tubercles migrate upward to a position above the venter, where they become larger than the outer ones (pl. 3, figs. 22-24). For about a quarter of a whorl or less, the outer tubercle is reduced to a small swelling on the side of the larger inner tubercle before disappearing (pl. 3 , fig. 24). The outer tubercles and the siphonal tubercles disappear at some diameter between 30 and $40 \mathrm{~mm}$. At this size, the inner ventrolateral tubercles become clavate and rise farther above the venter (pl. 3, fig. 27). At larger diameters, the tubercles form prominent clavate horns that are directed upward and a little outward (pl. 3, figs. 33, 34). Umbilical bullae migrate out to the middle of the flank, where they are usually prominent and nodate (pl. 3, fig. 34). Ribs become equal in length at diameters greater than $50 \mathrm{~mm}$. The 42 specimens from locality 23459 reveal a gradual decrease in rib density with growth (fig. 6).

Nearly all specimens from locality 23459 are phragmocones. Diameters at the base of the few body chambers range from 11 to $21 \mathrm{~mm}$. These specimens are probably immature inasmuch as adult ornament and crowded terminal sutures are lacking.

Ribs on the outer septate whorl and on the body chamber weaken considerably between the umbilical bullae and the ventrolateral horns as well as across the venter. On a few specimens, a very low, broad, flat rib connects opposite ventrolateral horns, and this rib may be raised a little along the edges to form a weak looped rib (pl. 3, fig. 29).

Acanthoceras muldoonense has a whorl section much like that of $A$. cornigerum Crick (1907, p. 207, pl. 13, fig. $1,1 a)$, especially like the whorl section drawn by Matsumoto (in Matsumoto and others, 1957, text fig. 5). Crick's South African species, however, is more evolute, and the ribs are narrower and more numerous.

The holotype and paratypes of Acanthoceras muldoonense came from iron-stained chamosite ironstone concretions in the Graneros Shale 4-6 m (13-20 ft) above the Thatcher Limestone Member in south-central Colorado. Specimens from the Frontier Formation in northcentral Wyoming occur in ferruginous concretions of calcareous siltstone. Other fossils in these concretions are scarse but include an occasional poorly preserved inoceramid and one fragment of Turrilites cf. T. scheuchzerianus Bosc.

Types.- Hypotypes USNM 388110-388122.

\section{Genus CUNNINGTONICERAS Collignon, 1937}

Type species.-Ammonites cunningtoni Sharpe, 1855.

Collignon (1937, p. 40) defined this genus to include ammonites that have a rectangular whorl section, multiplication of ribs and tubercles on the venter, and

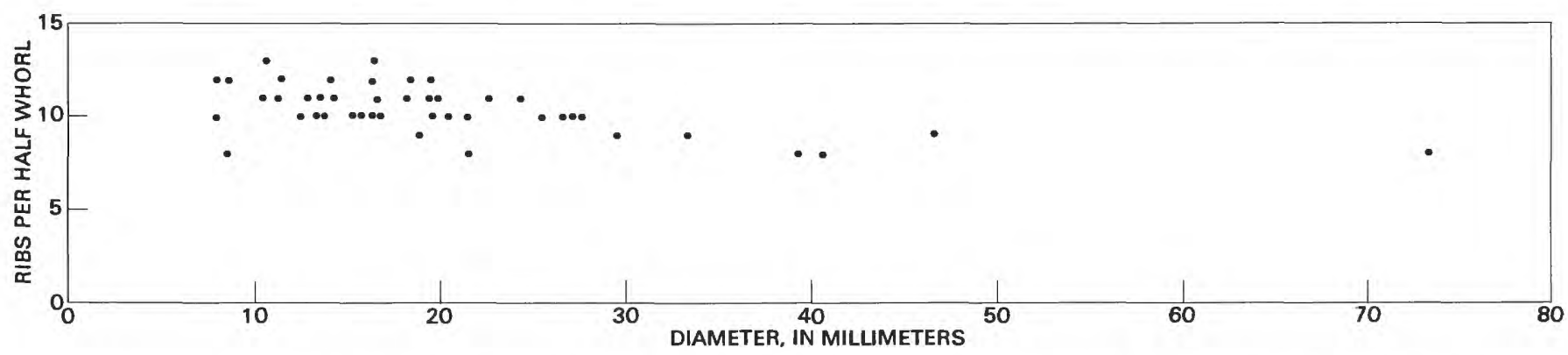

FIGURE 6.-Scatter diagram showing number of ribs per half whorl of Acanthoceras muldoonense Cobban and Scott from a bed of concretions in the Frontier Formation at locality 23459 near Kaycee, Wyo. (fig. 1). 
later loss of the ventral ornament accompanied by the enlargement of the ventrolateral tubercles. Collignon included in the genus Ammonites cunningtoni Sharpe, Acanthoceras cunningtoni var. inermis Pervinquière, $A$. cunningtoni var. cornuta Kossmat, $A$. diadema Spath, Ammonites meridionalis Stoliczka and its varieties africana Pervinquière and tuberculata Pervinquière, Acanthoceras lonsdalei Adkins, A. latum Crick, A. quadratum Crick, and A. aberrans Kossmat.

Cunningtoniceras has usually been considered a junior synonym of Euomphaloceras Spath (1923, p. 144, footnote 2) by most ammonitologists (e.g., Wright, 1957, p. L414; Matsumoto, in Matsumoto and others, 1969 , p. 270; Kennedy, 1971, p. 90). I believe the two genera are distinct enough to retain separate names. Cunningtoniceras has more Acanthoceras-like whorls with rectangular sections and a suture characterized by L usually narrower than the E/L saddle; whereas, Euomphaloceras has more depressed, rounded whorls and a suture featured by $\mathrm{L}$ generally broader than the E/L saddle. Cunningtoniceras is apparently the older form. Kennedy $(1971$, p. 102) recorded the cunningtoni-inerme group in both the Turrilites costatus Assemblage and T. acutus Assemblage of the middle Cenomanian Acanthoceras rhotomagense Zone. Euomphaloceras euomphalum (Sharpe), the type for the genus Euomphaloceras, occurs in the upper Cenomanian Eucalycoceras pentagonus/Calycoceras naviculare Assemblage Zone. The same order of genera is apparent also in the Western Interior of the United States. Cunningtoniceras is well established in the middle Cenomanian Thatcher Limestone Member of the Graneros Shale (Cobban and Scott, 1972, p. 30, recorded as Euomphaloceras cf. E. cunningtoni); whereas, upper Cenomanian rocks in the same area contain Euomphaloceras (Kanabiceras) septemseriatum (Cragin).

The type of Cunningtoniceras, by absolute tautonymy, is Ammonites cunningtoni Sharpe $(1855$, p. 35 , pl. 15, fig. 2a-c) from the middle Cenomanian Lower Chalk at Upton Scudamore, near Warminster, in southern England. Sharpe described the species briefly and gave its dimensions as "Diameter, 6 inches; width, $3 \frac{1 / 4}{4}$ inches; height of aperture, $2^{1 / 2}$ inches." The specimen was illustrated by drawings of the lateral and front views. Kennedy $(1971$, p. 92,93$)$ has more fully described the type, which is a phragmocone that consists of one complete whorl; the inner whorls are not preserved. The intercostal whorl section, at the larger end, is much broader than high. Ornament on the side of the whorl consists of 11 broad, low, rectiradiate ribs, each of which supports a strong bullate umbilical tubercle and a larger nodate ventrolateral tubercle or horn that is directed upwards and outwards. Regarding or- nament on the venter, Kennedy (1971, p. 93) observed that

At the smallest diameter visible there are 2 strong clavate upper ventro-lateral tubercles and 1 or $2 \mathrm{small}$ rounded tubercles $\mathrm{cn}$ a spirally elongate siphonal swelling, connected to the upper ventro-lateral tubercles by a broad low rib.

Between the long ribs there are 1 or 2 short intercalated ribs, extending across the venter only. These bear a rounded siphonal tubercle, or, in some cases, 2 smaller tubercles. With increasing size the intercalated ventral ribs disappear, as do the siphonal tubercles, whilst the ventro-lateral horn and upper ventro-lateral tubercle combine to form a large bituberculate horn. The siphonal region between the horns is depressed.

\section{Cunningtoniceras amphibolum (Morrow) Plates 4-8; plate 9, figures $48-63$}

Cunningtoniceras amphibolum is a moderate sized, somewhat evolute ammonite that has quadrate whorls with flattened flanks and very broadly rounded venter. Ribs are straight and rectiradiate to prorsiradiate; they are long and short on the innermost whorls and equal in length on the outer whorls. The ribs on the inner whorls bear umbilical bullae or bullate umbilical tubercles, nodate inner ventrolateral tubercles, and clavate outer ventrolateral and siphonal tubercles. On later whorls, the outer ventrolateral tubercles weaken and disappear, and the siphonal tubercles gradually weaken and merge into a low siphonal ridge. Inner ventrolateral tubercles become larger on the outer whorls and, on the body chamber of large adults, rise into prominent horns that are directed outward and upward. The species seems to be dimorphic. Cunningtoniceras amphibolum is widely distributed in the Western Interior from south-central Montana south to the vicinity of El Paso, Tex. (fig. 7).

Ammonites loevianus White (1877, p. 201, pl. 19, fig. 1a, b), from New Mexico, is closely related to if not identical to Cunningtoniceras amphibolum. White's species was treated briefly by Stanton (1893, p. 178, pl. 43, figs. $3,4)$, but since then the species has seldom been mentioned in the literature; the name is best considered a nomen oblitum.

Molluscan fossils usually found with C. amphibolum include Inoceramus arvanus Stephenson, I. rutherfordi Warren, Ostrea beloiti Logan, and Borissiakoceras reesidei Morrow. In the southern part of the Western Interior, a more varied ammonite fauna occurs with $C$. amphibolum. Important ammonites from that region are Desmoceras (Pseudouhligella) aff. D. japonicum Yabe, Paracompsoceras landisi Cobban, Tarrantoceras rotatile Stephenson, and Turrilites acutus americanus Cobban and Scott (Cobban, 1977). 


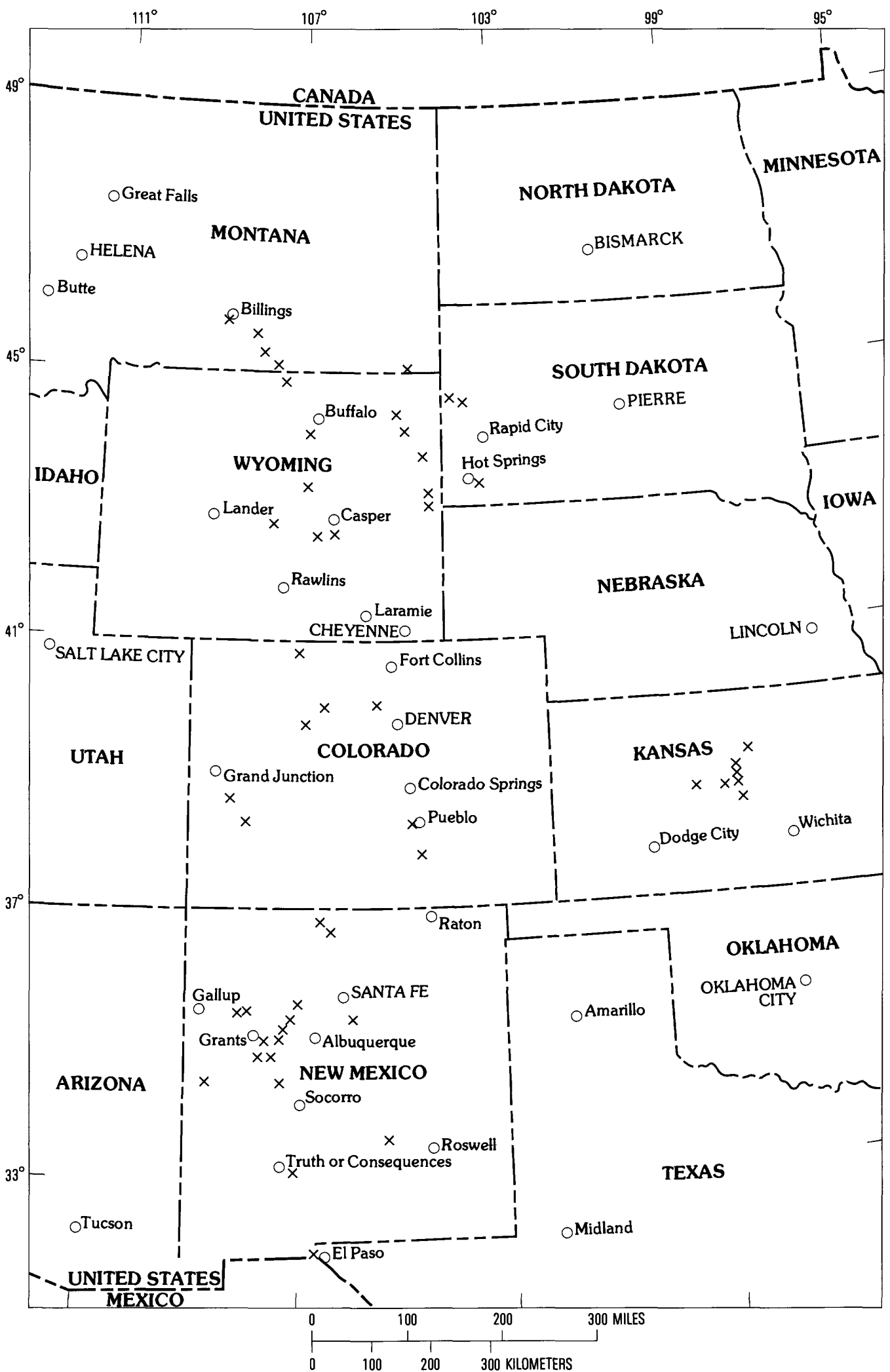

FIGURE 7.-Map showing localities (x) where Cunningtoniceras amphibolum (Morrow) has been found. 
Cunningtoniceras amphibolum amphibolum (Morrow)

Plate 4; plate 5, figures 1-25

1935. Acanthoceras? amphibolum Morrow, Journal of Paleontology, v. 9 , no. 6 , p. 470 , pl. 49 , figs. $1-4,6$; pl. 51 , figs. 3, 4; text fig. 4.

1942. Acanthoceras alvaradoense Moreman, Journal of Paleontology, v. 16, no. 2, p. 205, pl. 32, fig. 6; text figs. $2 o, 2 t$.

1952 (1953). Acanthoceras hazzardi Stephenson, U.S. Geological Survey Professional Paper 242, p. 201, pl. 48, figs. 1, 2; pl. 49, fig. 4.

1955. Euomphaloceras alvaradoense (Moreman). Stephenson, U.S. Geological Survey Professional Paper 274-C, p. 63, pl. 7, figs. 1-9.

1960. Acanthoceras amphibolum Morrow. Matsumoto, Kyushu University Faculty of Science, Science Reports, Geology, v. 5, no. 1, p. 41, text fig. 5b-d.

1960. Acanthoceras hazzardi Stephenson. Matsumota, Kyushu University Faculty of Science, Science Reports, Geology, v. 5, no. 1, p. 41, text fig. 5a.

1960. Acanthoceras alvaradoense Moreman. Matsumoto, Kyushu University Faculty of Science, Science Reports, Geology, v. 5, no. 1, p. 41, text fig. 6a-c.

1963. Paracanthoceras amphibolum (Morrow). Haas, American Museum Novitates 2151, p. 18.

1964. Plesiacanthoceras [amphibolum (Morrow)]. Haas, Journal of Paleontology, v. 38, no. 3, p. 610.

1965. Plesiacanthoceras amphibolum (Morrow). Hattin, Kansas Geological Survey Bulletin 178, pl. 4, figs. J, K; pl. 5, figs. C-F.

1965. Plesiacanthoceras amphibolum (Morrow). Hattin, Geological Society of America Field Conference Guidebook, Upper Cretaceous stratigraphy, paleontology, and paleoecology of western Kansas, Annual Meetings, 1965, text fig. 3 (photo 8).

1966. Acanthoceras amphibolum Morrow. Matsumoto and Obata, National Science Museum [Tokyo] Bulletin, v. 9, no. 1 , p. 45 , text figs. 4-6.

1966. Acanthoceras hazzardi Stephenson. Matsumoto and Obata, National Science Museum [Tokyo] Bulletin. v. 9 , no. 1 , p. 45 , text fig. 7 .

1968. Plesiacanthoceras [amphibolum Morrow]. Laporte, Ancient environments (Prentice-Hall), text fig. 6-10H.

1969. Acanthoceras amphibolum Morrow. Matsumoto, Muramoto, and Takahashi, Kyushu University Faculty of Science Memoirs, Series D, Geology, v. 19, no. 2, p. 266, pl. 31, fig. 1a, b.

1972 (1973). Acanthoceras amphibolum Morrow. Cobban and Scott, U.S. Geological Survey Professional Paper 645, p. 65 (part).

1977. Acanthoceras alvaradoense Moreman. Cobban, U.S. Geological Survey Professional Paper 1009, p. 24, pl. 6, figs. 1-7, 11-20; text fig. 6.

1977. Acanthoceras amphibolum Morrow. Hattin, The Mountain Geologist, v. 14, nos. 3-4, p. 183, fig. 13.

1978. Acanthoceras amphibolum Morrow. Hattin and Siemers, Kansas Geological Survey Guidebook Series 3, fig. 5 (photo 14).

1979. Acanthoceras alvaradoense Moreman. Merewether, Cobban, and Cavanaugh, The Mountain Geologist, v. 16, no. 3, pl. 1, figs. 3-7.

1985. of the British Museum (Natural History), Geotogy Series, v. 39 , no. 1 , p. 35 , figs. $38-41$.

Morrow (1935) illustrated four syntypes from the upper part of the Graneros Shale of central Kansas as well as a plaster cast of a large adult in the National Museum of Natural History, Washington, D.C. The four syntypes, which are well-preserved, uncrushed, internal molds, apparently all came from one or more limestone concretions at one locality. In addition to good photographs of these four syntypes, Morrow (1935, text fig. 4) presented a drawing of the whorl section of the largest of them. At a later date, Matsumoto (1960, text fig. 5BD) showed a new drawing of this whorl section as well as drawings of the whorl sections of two other syntypes. Morrow's description of his species is generalized and based on other specimens as well as the syntypes. Three of the syntypes are worthy of more detailed descriptions.

The smallest syntype (pl. 4, figs. 1-3), which has a diameter of $27.3 \mathrm{~mm}$ and an umbilical ratio of 0.25 , consists of a phragmocone and nearly half a whorl of body chamber. Diameter at the base of the body chamber is $19.3 \mathrm{~mm}$. The last septa are not crowded, which suggests that the specimen is immature. Ornament is strong on the outer whorl, where ribs are mostly of equal length and number 15 . Longer ribs arise from nodate umbilical bullae, and all ribs bear nodate inner ventrolateral tubercles and clavate outer ventrolateral and siphonal tubercles. All clavate tubercles are asymmetric with steep adoral slopes. The tuberculated ribs cross the venter as broad folds slightly arched forward.

The second smallest syntype (pl. 4, figs. 4-6), which is herein designated as the lectotype, has a diameter of $55.8 \mathrm{~mm}$ and an umbilical ratio of 0.28 ; it is chiefly a phragmocone with a bit of the body chamber. Matsumoto $(1960$, fig. $5 \mathrm{~B})$ has drawn its squarish whorl section. Diameter at the base of the body chamber is $53 \mathrm{~mm}$. Inasmuch as the last septa are not crowded, the specimen may represent an immature individual. Ribs on the outer whorl number 18 and are prorsiradiate and equal in length. The ribs begin on the steep umbilical wall, rise into umbilical bullae on the lower part of the flank, cross the flank with slight forward inclination, and rise again into nodate to clavate inner ventrolateral tubercles and clavate outer ones, which are set forward a little. Opposite ventrolateral tubercles may or may not be connected across the venter by weak, poorly defined ribs that support weak clavate siphonal tubercles. These scarcely visible ventral ribs are separated by faint secondary ventral ribs that have outer ventrolateral and siphonal tubercles.

The third syntype (Morrow, 1935, pl. 49, fig. 1), of which Matsumoto (1960, fig. 5C) has shown its whorl section, is half a specimen of $95 \mathrm{~mm}$ diameter with an umbilical ratio of 0.30 . Most of the outer whorl is unchambered and probably represents the older half of a 
body chamber that had a diameter of about $70 \mathrm{~mm}$ at its base. Ribs on the last half whorl numbered about 10. These ribs begin near the umbilical seam and slant forward to the umbilical shoulder, where they rise into umbilical bullae on the lower part of the flank. The ribs then bend back slightly before crossing the flank. Each rib terminates in a prominent inner ventrolateral tubercle, which is clavate on the older part of the whorl and horn-like on the younger part. Very weak clavate outer ventrolateral tubercles are present on the older end of this half whorl, but these weaken further and disappear. A low siphonal ridge is present on the entire half whorl. On the older part of the whorl, the siphonal ridge is weakly beaded by faint forwardly arched ventral riblets.

Innermost whorls of Cunningtoniceras amphibolum were not illustrated by Morrow. According to Morrow (1935, p. 470,472$)$, whorls at a diameter of $2 \mathrm{~mm}$ are wider than high and broadly rounded, and they are smooth except for a row of pointed, conical lateral tubercles. These tubercles migrate ventrally as the shell enlarges, and by a diameter of $5 \mathrm{~mm}$, they become the inner ventrolateral row. At this diameter outer ventrolateral and siphonal tubercles appear, as well as ribs. The whorl assumes a subquadrate section by a diameter of $15 \mathrm{~mm}$.

The suture is typical of the genus in that it is only moderately digitate with broad bifid $\mathrm{E} / \mathrm{L}$ and a rectangular bifid L. Morrow (1935, pl. 51, figs. 3, 4) illustrated two external sutures.

Fossils from Kansas in the collections of the U.S. Geological Survey at the Denver Federal Center include only one specimen (hypotype USNM 388123) from the type locality of $C$. amphibolum. This specimen (pl. 4, figs. 7-9), from locality 12510 (fig. 1), is preserved exactly like Morrow's syntypes. The specimen may be nearly complete; it has a diameter of $72 \mathrm{~mm}$ and an umbilical ratio of 0.30 . The last half whorl is a body chamber that has a diameter of $51.3 \mathrm{~mm}$ at its base. Septa are uniformly spaced, which suggests an immature individual. Whorls are subquadrate and a little wider than high. Ornament on the outer whorl consists of 17 equal rounded ribs that are narrower than the interspaces and have umbilical bullae, nodate inner ventrolateral tubercles, and clavate outer ventrolateral and siphonal ones. Siphonal tubercles, although weakening, persist to the end of the specimen. On the older part of the outer whorl, the clavate siphonal tubercles are separated by a smaller nodate siphonal tubercle located on a faint secondary ventral rib (pl. 4, fig. 8).

Morrow's four syntypes came from the upper part of the Graneros Shale on the "south bank of Smoky Hill River south of Wilson, Ellsworth County, Kansas". (Morrow, 1935, p. 473). On the Wilson 71/2-minute quadrangle, the collection is from the $\mathrm{S}^{1} 1 / 2 \mathrm{~S}^{1} / 2$ sec. $31, \mathrm{~T}$. $14 \mathrm{~S}$.,
R. $10 \mathrm{~W}$., about $4 \mathrm{~km}\left(2 \frac{1}{2} \mathrm{mi}\right)$ south of Wilson. The collection made by N.W. Bass and others at this locality (fig. 1, loc. 12510) was said to have come from " 4 feet below top of Graneros Shale" (original label with the collection). Hattin (1965a, p. 76, 77) measured a section nearby and noted the presence of $C$. amphibolum in the

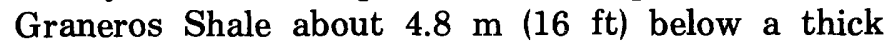
widespread bed of bentonite referred to as the bentonite marker bed, which lies about $0.9 \mathrm{~m}$ below the top of the Graneros Shale at this locality.

Hattin (1965a, pl. 4, figs. J, K; pl. 5, figs. C-F) illustrated several good examples of C. amphibolum from $3.4 \mathrm{~m}(11 \mathrm{ft})$ below the bentonite marker bed at a locality $12 \mathrm{~km}(8 \mathrm{mi})$ southeast of the type locality of the species. Among them is a large body chamber of half a whorl about $210 \mathrm{~mm}$ in diameter (Hattin, 1965a, pl. 5 , figs. C, E). Ornament is sparse and consists of five very widely spaced straight, rectiradiate ribs of which all but the final one have umbilical bullae and ventrolateral horns. Outer ventrolateral tubercles and siphonal tubercles have disappeared at this large size. Opposite horns are connected across the venter by broad, low, flat, transverse ribs, which are raised a little along the margins to form looped ribs. The final rib at the aperture is narrow and forms a flange like that of a specimen from near Pueblo, Colo. (Cobban and Scott, 1972, pl. 10, fig. 16).

A collection made by me at Hattin's locality (fig. 1, loc. D4428) revealed marked dimorphism in adult specimens of $C$. amphibolum (pl. 4, figs. 10, 11). Adult body chambers are characterized by a loss of the outer ventrolateral and siphonal tubercles and by the development of the inner ventrolateral tubercles into horns. Diameters at the base of the few measurable adult body chambers range from 53 to $115 \mathrm{~mm}$.

Earliest whorls are either not visible or not well enough preserved for study in the collection from locality D4428. An excellent collection from the Graneros Shale at locality D5900 (fig. 1) southwest of the Black Hills in eastern Wyoming includes many small whorls (pl. 5, figs. 1-25). The earliest whorl examined, at a diameter of $1 \mathrm{~mm}$, is smooth, well rounded, and wider than high. Tubercles appear at some diameter around $3 \mathrm{~mm}$. At diameters of 5-9 mm nodate, equal-sized inner and outer ventrolateral and siphonal tubercles form a forwardly arched row across the venter bounded on the adoral side by a low constriction. There are 5-7 rows per half whorl; the rows are well separated by smooth areas. At some diameter between 9 and $12 \mathrm{~mm}$, ribs develop along the tubercles, and another row of tubercles usually arises on the adoral side of the constriction, or the constriction disappears, and a weak untuberculated rib may form midway between the tuberculated ribs. These rib arrangements and constrictions were not 
mentioned by Morrow. On the early whorls from locality D5900, ribs usually lengthen to the umbilicus at a diameter of about $10 \mathrm{~mm}$, and umbilical bullae arise at diameters from 7 to $12 \mathrm{~mm}$.

Forty specimens, 7-117 mm in diameter, from locality D5900 are suitable for determination of two or more of the following measurements: diameter of shell, diameter of umbilicus, diameter at base of body chamber, and number of ribs per half whorl. Diameters at the base of body chambers, which could be determined for 17 specimens, ranged from 13.3 to $114 \mathrm{~mm}$. Sixteen of these specimens have measurements of 13.3-44.7 mm, but inasmuch as none of these has crowded terminal sutures or ventrolateral horns, they may represent immature individuals. Ribs on the specimens from locality D5900 are mostly of uniform length and number 8-14 in half a whorl, averaging 9.1. Fifteen of the specimens have at some growth stage secondary ribs on the venter. These ribs are weaker than the primary ones and usually support weak outer ventrolateral and siphonal tubercles. Only one secondary rib separates the primaries. Secondary ribs on the venter were not observed at diameters larger than $41 \mathrm{~mm}$.

Morrow did not record the presence of secondary ribs and tubercles on the venter of C. amphibolum, nor did he record the presence of constrictions on the earliest whorls. These facts led to considerable confusion as to the concept of the species. A form, now known to be younger than C. amphibolum amphibolum, occurs at many localities in the Western Interior of the United States. Adults cannot be separated from those of $C$. amphibolum amphibolum, but the inner whorls generally lack constrictions and extra ventral ornament. Specimens of this type were considered as Acanthoceras amphibolum; however, those with constrictions and extra ventral ornament were assigned to $A$. alvaradoense Moreman (Cobban, 1977, p. 23, 24). Acanthoceras amphibolum and A. alvaradoense are the same subspecies and should be assigned to Cunningtoniceras. The slightly younger specimens that usually lack extra ventral ornament are herein assigned to the new subspecies $C$. amphibolum fallense.

Cunningtoniceras amphibolum amphibolum has been found at many localities in the Western Interior. A number of localities are clustered in the central part of Kansas (fig. 7), where the subspecies occurs as undeformed specimens in limestone concretions or as flattened impressions in shale in the upper part of the Graneros Shale below the bentonite marker bed. Farther northwest, near the central eastern boundary of Wyoming, limestone concretions below the bentonite marker bed in the upper part of the Graneros Shale, contain excellent specimens of $C$. amphibolum amphibolum (fig. 1, loc. D5900). The subspecies has not been positively identified farther west in Wyoming or southward in Colorado. However, it occurs at many localities in westcentral New Mexico, where it was recorded as Acanthoceras alvaradoense in the Clay Mesa Tongue of the Mancos Shale (Cobban, 1977, table 1 and p. 24). The subspecies is also abundant and well preserved in calcarenite at the base of the Boquillas Formation in New Mexico just west of El Paso, Tex. (fig. 1, loc. D10142), where it was recorded as $A$. alvaradoense (Strain, 1976, p. 82).

Types.-Hypotypes USNM 388123-388135.

Cunningtoniceras amphibolum fallense Cobban, n. subsp.

Plate 5, figures 26, 27; plates 6-8; plate 9, figures 48-63

1972. Acanthoceras amphibolum Morrow. Cobban and Scott, p. 65 (1973) (part), pl. 9; pl. 10, figs. 12-16; text fig. 26.

1976. Acanthoceras amphibolum Morrow. Kauffman, Cobban, and

(1978) Eicher, Muséum d'Histoire Naturelle de Nice Annales, v. 4, p. XXIII. 39, figs. 1, 2.

1977. Acanthoceras amphibolum Morrow. Cobban, U.S. Geological Survey Professional Paper 1009, p. 23, pl. 8, figs. 8, 9; pl. 12, figs. 10-12, 15-23; text fig. 5.

1977. Acanthoceras amphibolum Morrow. Kauffman, The Mountain Geologist, v. 14 , nos. $3-4$, pl. 15 , figs. 1,2 .

1979. Acanthoceras amphibolum Morrow. Merewether, Cobban, and Cavanaugh, The Mountain Geologist, v. 16, no. 3, pl. 1, figs. $1,2,8,9$.

This chronologic subspecies usually lacks multiplication of ventral ornament. Like the nominate subspecies, C. amphibolum fallense is dimorphic. Many of the microconchs seem to be slightly more slender and more evolute than similar sized microconchs of $C$. amphibolum amphibolum (fig. 8). The holotype (pl. 5, figs. 26, 27) and several of the figured paratypes (pl. 6) of C. amphibolum fallense came from limestone concretions developed along the bentonite marker bed near the top of the Belle Fourche Shale at locality D7370 in southwestern South Dakota (fig. 1). This collection contains 19 specimens 24-150 $\mathrm{mm}$ in diameter that are suitable for the determination of three or more of the following measurements: diameter of the shell, diameter of the umbilicus, diameter of the base of the body chamber, and the number of ribs in half a whorl.

The holotype (pl. 5, figs. 26, 27) is a small adult macroconch $132 \mathrm{~mm}$ in diameter with an umbilicus of $51.4 \mathrm{~mm}$ (ratio 0.39). The specimen, an uncrushed internal mold badly weathered on one side, is made up of a nearly complete body chamber and the outer $1 \frac{1 / 2}{2}$ whorls of the phragmocone. Innermost whorls are not preserved. The last septate whorl has a rectangular intercostal section that is slightly higher than wide with flattened flanks and venter and steep umbilical wall. Ribs, which number 18 on this whorl, are straight, 


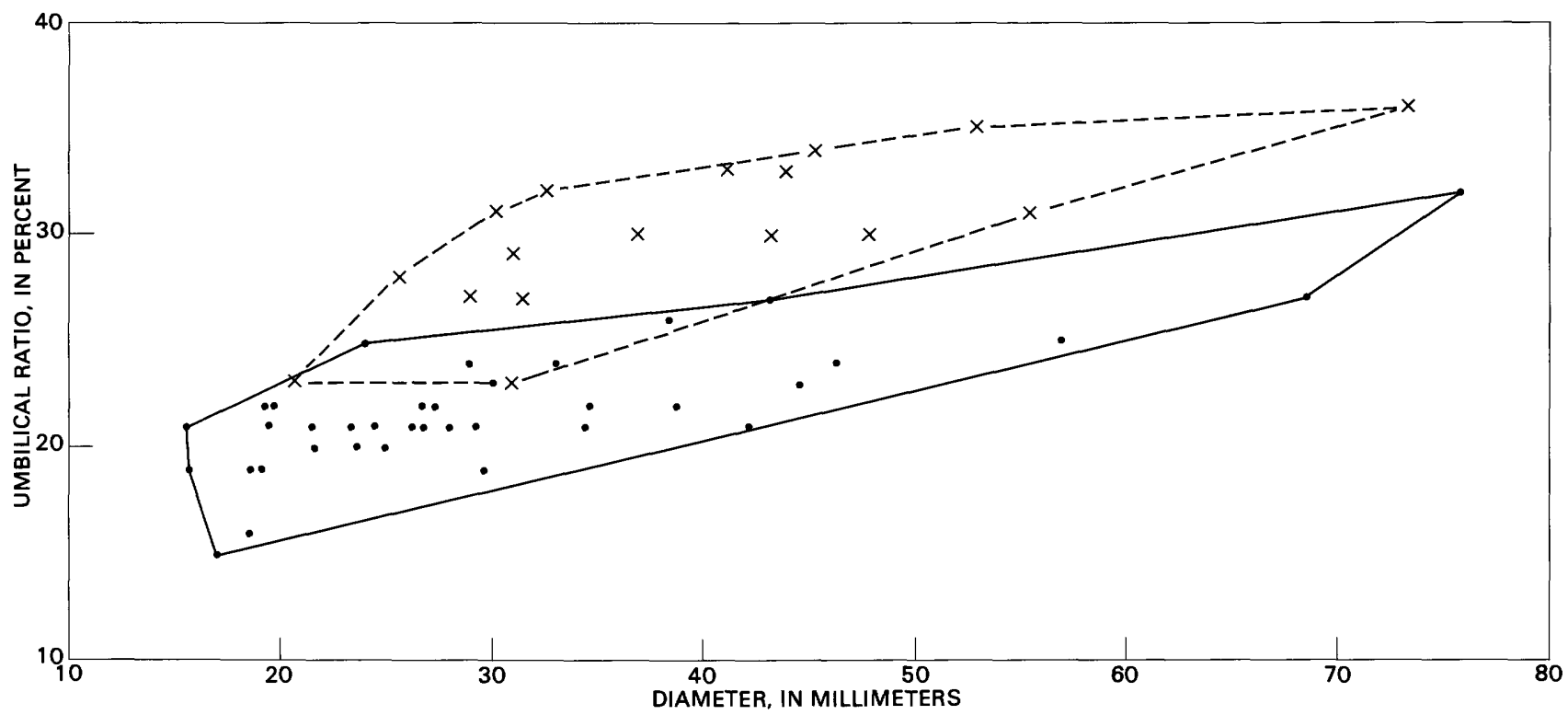

Figure 8.-Scatter diagram of umbilical ratios of Cunningtoniceras amphibolum amphibolum ( $\bullet$ ) from the Belle Fourche Shale at locality D5900 (fig. 1) and C. amphibolum fallense (x) from the Belle Fourche Member at locality 20934 (fig. 1).

rounded, prorsiradiate, equal in length, and narrower than the interspaces. Each rib begins on the outer part of the umbilical wall, rises into a forwardly inclined bulla on the narrowly rounded umbilical shoulder, crosses the flank, and rises again into a conspicuous nodate inner ventrolateral tubercle. From there, a forwardly arched, broad, very low swelling crosses the flattened venter. This swelling supports low, clavate outer ventrolateral and siphonal tubercles on the older part of the whorl, but these disappear on the younger part. Diameter of the phragmocone at the base of the body chamber is $102.4 \mathrm{~mm}$. The body chainber, which occupies half a whorl, has a squarish section with broadly rounded flanks and venter, well-rounded umbilical shoulder, and gently sloping umbilical wall. Ornament consists of 5 straight, rectiradiate ribs, 4 of which bear prominent nodate umbilical tubercles and inner ventrolateral horns that are directed upward and outward. The fifth or final rib forms a flange that curves forward on crossing the venter. Ribs on the body chamber are much farther apart than those on the phragmocone. Opposite ventrolateral horns are connected across the venter by broad, flat areas that may or may not be elevated a little. Only the ventral margin of the aperture is preserved; it is broadly convex forward. Sutures on the holotype are poorly preserved, but they seem typical of the species.

Of the 19 specimens suitable for measurements from locality D7370, only one shows extra ventral ornainent. This specimen, which is half a whorl of $36 \mathrm{~mm}$ diameter, has weak nontuberculated ventral ribs alternating with the stronger tuberculated primary ribs. Occasional specimens have closely spaced riblets on the venter and flanks (pl. 6, figs. 1-4, 7), and on one individual, these riblets seem to have replaced the normal ribbing on part of the whorl (pl. 6, fig. 7).

The specimens from locality D7370 are dimorphic. Microconchs have body chainbers characterized by loss of outer ventrolateral and siphonal tubercles and with or without the development of inner ventrolateral horns. Outer ventrolateral and siphonal tubercles weaken and disappear on the last quarter of the outer septate whorl, or at the base of the body chamber, or on the older part of the body chamber. Ventrolateral horns form only on the larger microconchs. The 14 specimens that can be considered as microconchs have the following diameters in millimeters (rounded) at the base of the body chainbers: $36,45,51,55,57,60,60,64,68,73,73,74$, 75 , and 77. Macroconchs, represented by only 5 specimens, resemble the larger microconchs in their horn development. Diameters in millimeters (rounded) at the base of the body chambers range from 102 (holotype) to an estimated 210.

The specimens from locality D7370 are from the southeast flank of the Black Hills uplift in Fall River County, S. Dak., which is the source of the subspecies naine. Associated fossils include abundant Inoceramus arvanus Stephenson and Ostrea beloiti Logan, a single small hamitid, and numerous Borissiakoceras reesidei Morrow and Protacanthoceras hosei Cobban, n. sp.

Another large collection of $C$. amphibolum fallense (pl. 7) is from very fine grained sandstone concretions in the upper part of the Frontier Formation at locality 22804 in north-central Wyoming (Hose, 1955, p. 100). Thirtytwo specimens from 18 to $123 \mathrm{~mm}$ in diameter are 
suitable for measurements. Only 4 of these, which have diameters of 27-36 mm, have slight multiplication of ventral ornament. Diameters at the base of the body chambers could be determined or estimated for 27 specimens (fig. 9). Fifteen of these, which have diameters of $18.3-51 \mathrm{~mm}$ at the base of the body chamber, may be considered microconchs because outer ventrolateral and siphonal tubercles disappear at or near the base of the body chamber. Inner ventrolateral tubercles persist on the body chamber, where they become large and conspicuous but not horn-like. Only one of the microconchs has crowded terminal sutures. Specimens that may be considered macroconchs have diameters at the base of body chambers of 61-123 mm. Body chambers have ventrolateral horns. Even these specimens seem to be dimorphic with 10 of them that have diameters at the base of the body chamber of 61-94 mm and with 2 that have diameters of 110 and $123 \mathrm{~mm}$.

The subspecies attains diameters of nearly $200 \mathrm{~mm}$. One of the large specimens (pl. 8) from locality D8442 (fig. 1) shows a rejuvenation of cunningtonicerid ventral ornament at a very large diameter.

Cunningtoniceras amphibolum fallense has been found at many localities in the Western Interior. Specimens are exceptionally well preserved in limestone concretions developed along a widespread thick bed of bentonite in the upper part of the Belle Fourche Shale in the Black Hills area of western South Dakota, eastern Wyoming, and southeastern Montana. This bed of bentonite was informally referred to as the gray-red bentonite by M. N. Bramlette and W. W. Rubey (in Moore, 1949, fig. 18; also see Robinson and others, 1964, p. 53); it has also been designated as bed $\mathrm{F}$ by Knechtel and Patterson (1955; 1962, p. 982). Farther northwest, in south-central Montana, this bed was formally named the Soap Creek Bentonite Bed of the Belle Fourche Member of the Cody Shale (Knechtel and Patterson, 1952; 1956, p. 18). In this area, limestone concretions associated with the bentonite locally contain well-preserved specimens of $C$. amphibolum fallense, some with nacreous shells. At one locality (fig. 1, loc. 24319), specimens lying on

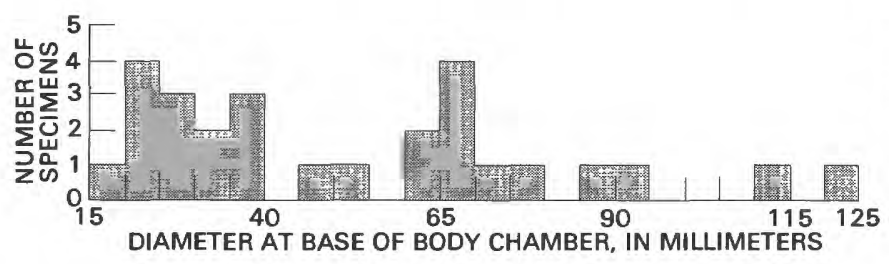

FIGURE 9.-Histogram showing diameters at base of body chambers of the 27 measurable specimens of Cunningtoniceras amphibolum fallense Cobban, n. subsp., from the Frontier Formation at locality 22804 (fig. 1). the Soap Creek Bentonite Bed have been replaced by silica derived from the bentonite. In eastern Colorado, a widely distributed bed of bentonite that is probably a continuation of the Soap Creek Bed, has been informally referred to as the marker bentonite bed and considered as the base of the Greenhorn Limestone (Cobban and Scott, 1972, p. 16, fig. 10). Concretionary limestone developed along this bed of bentonite contains $C$. amphibolum fallense. This subspecies occurs in sandstone farther southwest in the northern and west-central parts of New Mexico.

Types.-Holotype USNM 388136, paratypes USNM 388137-388151.

\section{Genus PLESIACANTHOCERAS Haas, 1964}

Type species.-Metoicoceras wyomingensis Reagan, 1924.

This genus, originally named Paracanthoceras Haas (1963, p. 2), was renamed Plesiacanthoceras by Haas (1964), after he found that his earlier name was preoccupied by Paracanthoceras Furon (1935, p. 59). The original generic description (Haas, 1963, p. 2, 3) is as follows:

Involute in youth, becoming increasingly more evolute with growth. Whorl section rectangular to subquadratic, with gently convex flanks and truncate venter. Ornamentation consisting of radial ribs which gradually disappear, circumumbilical tubercles gradually shifting away from umbilical shoulder and developing into horns, inner and outer lateroventral tubercles, outer ones more pronouncedly elongated spirally; both eventually merging into large horns that point outward and upward. Inconspicuous median tubercles, present in youth only, forming an intermittent keel which soon fades. Suture line characterized by particularly high outer main stem of very large external saddle and by wide first lateral lobe which is mostly bifid.

Plesiacanthoceras has been considered a synonym of Acanthoceras by several authors (Matsumoto, 1960, p. 43; Matsumoto and Obata, 1966, p. 45-47; Kennedy, 1971, p. 85; Juignet and Kennedy, 1976, p. 113). However, I believe that the very early loss of siphonal tubercles and the development of conspicuous nodate umbilical tubercles and ventrolateral horns seem distinctive enough from Acanthoceras to retain the separation. Plesiacanthoceras was derived from Cunningtoniceras by an earlier loss of siphonal tubercles and by the upward projection of the outer ventrolateral clavi well above the middle of the venter on the intermediate inner whorls. The inner whorls of Plesiacanthoceras are much like those of Dunveganoceras; whereas, the outer whorl of Plesiacanthoceras is like that of horned Cunningtoniceras. Plesiacanthoceras is transitional from the older Cunningtoniceras to the younger Dunveganoceras. The genus is known from rocks of late middle Cenomanian age in the Western Interior. 
Plesiacanthoceras wyomingense (Reagan)

Plate 10, figures 48-82; plates 11-13

1924. Metoicoceras wyomingensis Reagan, Pan-American Geologist, v. 41 , no. 3 , p. 181 , pl. 19 , figs. 1,2 .

1946. Prionotropis woollgari Meek (?non Mantell) forma typica? Haas, American Museum of Natural History Bulletin, v. 86 , art. 4, p. 153, 157, 161, 164, 172, 185, 197, pl. 14, fig. 11.

1949. Collignoniceras woollgari (Meek, non Mantell) forma typica? Haas, American Museum of Natural History Bulletin, v. 93 , art. 1, p. 29 , footnote 2.

1949. "Mammites" n. sp. Haas, American Museum of Natural History Bulletin, v. 93, art. 1, p. 28.

1949. Dunveganoceras sp. indet. Haas, American Museum of Natural History Bulletin, v. 93, art. 1, p. 30, pl. 15, figs. 1-3; text fig. 10.

1951. Acanthoceras? n. sp. Cobban. American Association of Petroleum Geologists Bulletin, v. 35, no. 10, p. 2182, text fig. 2.

1952. Acanthoceras? sp. A. Cobban and Reeside, Geological Society of America Bulletin, v. 63, no. 10, p. 1017, chart 10B.

1955. Acanthoceras athabascense Warren and Stelck, Research Council of Alberta Report 70, p. 71, pl. 6, figs. 5, 6; pl. 7, figs. 1, 3, 4; pl. 8, figs. 1-3; pl. 9, fig. 2.

1958. Acanthoceras? wyomingense (Reagan). Cobban, Wyoming Geological Association Guidebook 13th Annual Field Conference, Powder River Basin, p. 118, text fig. 2.

1963. Paracanthoceras wyomingense (Reagan). Haas, American Museum Novitates 2151, p. 3, text figs. 1-12.

1964. Plesiacanthoceras wyomingense (Reagan). Haas, Journal of Paleontology, v. 38 , no. 3, p. 610.

1966. Acanthoceras wyomingense (Reagan). Matsumoto and Obata, National Science Museum [Tokyo] Bulletin, v. 9, no. 1, p. 45-47.

1968. Plesiacanthoceras wyomingense (Reagan). Hattin, Journal of Paleontology, v. 42 , no. 4 , p. 1084 , text figs. $3,4$.

1975. Acanthoceras wyomingense (Reagan). Hattin, Kansas Geological Survey Bulletin 209, pl. 4, figs. D, F.

1976. Plesiacanthoceras wyomingense (Reagan). Kauffman, Cobban,

(1978) and Eicher, Annales du Muséum d'Histoire Naturelle de Nice, v. 4, pl. 5, figs. $15,16$.

1977. Plesiacanthoceras wyomingense (Reagan). Kauffman, The Mountain Geologist, v. 14, nos. 3-4, pl. 22, figs. 15, 16.

1979. Plesiacanthoceras wyomingense (Reagan). Merewether, Cobban, and Cavanaugh, The Mountain Geologist, v. 16, no. 3 , pl. 1, figs. 15, 16 .

The holotype, Stanford University 119 , is a poorly preserved, worn, internal mold of half a phragmocone. Haas $(1963$, p. 4), who examined the type, gave its diameter as $120 \mathrm{~mm}$, its umbilicus as $18 \mathrm{~mm}(0.15)$, its height as $50.5 \mathrm{~mm}$, and its width as $38 \mathrm{~mm}$. Whorl section is rectangular with flattened flanks and venter and low, sloping umbilical wall. Ornament, which is fairly weak, consists of about 5 umbilical bullae and 10 equalsized inner and outer ventrolateral tubercles. Inner ventrolateral tubercles are nodate to slightly clavate, and outer ones are clavate; the latter ones rise above the flat, somewhat depressed venter. The specimen came from the Frontier Formation somewhere northwest of Casper, Wyo.
Plesiacanthoceras wyomingense is widely distributed mainly in Wyoming (fig. 10). Most collections are from silty concretions in the Frontier Formation, but the best preserved specimens are from limestone concretions in the Belle Fourche Shale along the north and northwest flanks of the Black Hills.

A collection from locality 22871, near Alzada, Mont. (fig. 1), includes many minute ammonites, some of which are probably juveniles of $P$. wyomingense. The shells of many of these juveniles are damaged at the base of the body chamber, probably owing to the work of some sort of predator. The smallest specimen that seems assignable to this species is a juvenile $10.4 \mathrm{~mm}$ in diameter (pl. 10, figs. 48-50). This specimen (hypotype USNM 388152 ) has a quarter of the body chamber preserved. The outer septate whorl is wider than high with very broad gently rounded venter, narrow flattened flanks, well rounded umbilical shoulder, and steep umbilical wall. Ornament on the older half of this septate whorl consists of 5 low, rounded, rectiradiate ribs that support small, pointed, nodate inner and outer ventrolateral tubercles matched by low siphonal clavi. A low, barely visible, slightly trituberculate secondary ventral rib crosses the venter transversely between the primary ones. The body chamber of this juvenile has a more quadrangular section. Ribs begin from umbilical bullae located on the umbilical shoulder, and the inner ventrolateral tubercles become a little clavate. Faint secondary ventral ribs were observed on another juvenile (hypotype USNM 388153), on which the secondaries disappeared at a diameter of $10.5 \mathrm{~mm}$ (pl. 10, figs. 51-53).

As the shell enlarges, the intercostal whorl section becomes more slender, and most specimens $18-160 \mathrm{~mm}$ in diameter have subrectangular intercostal sections higher than wide with the greatest width at the umbilical shoulder (pl. 10, figs. 63-82).

Ribs are conspicuous only on juveniles that have diameters less than $80 \mathrm{~mm}$. On these specimens, ribs are alternately long and short. The longer ribs begin on the umbilical wall and bend forward a little to the umbilical shoulder, where they rise into conspicuous bullae. The ribs then bend back slightly and cross the flank rectiradially or prorsiradially. Shorter ribs arise at the umbilical shoulder or about midflank. All ribs become broad at the ventrolateral shoulder and cross the venter transversely as low, wide bulges. Each rib supports a nodate to slightly clavate inner ventrolateral tubercle and a clavate outer one and, on the smaller specimens, a weak clavate siphonal tubercle. The outer ventrolateral ones are asymmetric with steep adoral sides. Ventrolateral tubercles number 8-12 per half whorl.

As the shell enlarges, secondary ribs disappear, and 


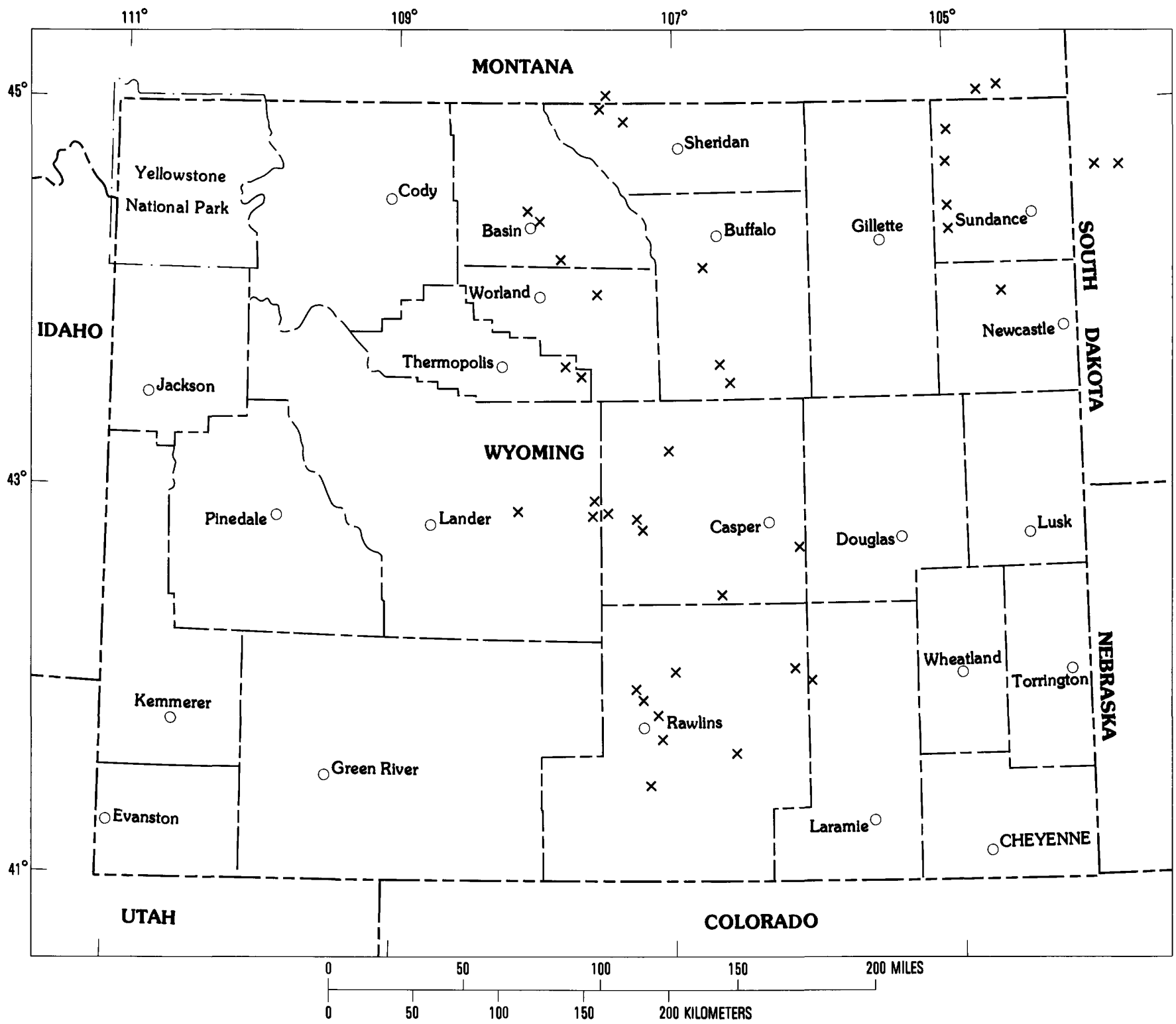

FIGURE 10.-Map of Wyoming showing localities $(\mathrm{x})$ where Plesiacanthoceras wyomingense (Reagan) has been found.

the umbilical tubercles become stronger and nodate and migrate out onto the lower part of the flank (pl. 11, fig. 13; pl. 12, fig. 2). Outer ventrolateral tubercles become weak and disappear at some diameter between 110 and $150 \mathrm{~mm}$. As these tubercles disappear, the inner ventrolateral tubercles enlarge into conspicuous clavate horns that are directed outwards and a little upwards (pl. 11, figs. 12,13). Various growth states can be seen on two individuals (hypotype USNM 388165 on pl. 11, figs. 3-7 and pl. 12, and hypotype USNM 388167 on pl. 11, figs. 10-13).
Ribs on the larger adults are usually very low, flat, and inconspicuous; they may disappear at midflank or on the venter. On some specimens, low looped ribs connect opposite ventrolateral horns, or they may connect the horns to the umbilical nodes. A fragment of a septate whorl (hypotype USNM 388168) that retains its shell material revealed slightly raised growth lines crossed at right angles by closely spaced fine spiral lines (pl. 13, fig. 4).

Large adults of half a whorl or more are not present in the collection from locality 22871 , although there are 
several fragments of large body chambers. For illustrations of a complete adult, the reader is referred to Haas (1963, text figs. 10-12). The species is probably dimorphic, although this cannot be proven with the material at hand.

Some specimens from the Frontier Formation of southcentral Wyoming differ from those from the Belle Fourche Shale of the Black Hills area in that siphonal clavi are retained to diameters of $70-110 \mathrm{~mm}$. In this respect, the specimens are like one of the paratypes of Acanthoceras athabascense Warren and Stelck (1955, pl. 7, fig. 1).

The suture is much like that of Acanthoceras. The lateral lobe (L) and adjoining saddles show well on one of the specimens figured by Haas $(1963$, fig. 8 ) as well as on the large phragmocone shown in plate 12 of the present report.

Ammonites associated with $P$. wyomingense at locality 22871 include two species originally described from Texas as Acanthoceras cuspidum Stephenson (1952, p. 202, pl. 50, figs. 1-4) and Borissiakoceras orbiculatum Stephenson (1955, p. 64, pl. 6, figs. 1-4). The former came from the Woodbine Formation, and the latter came from the basal beds of the Eagle Ford. Kennedy (1971, p. 97, 121) regarded $A$. cuspidum as a Protacanthoceras, but later Wright and Kennedy (1980, p. 99) considered it as a possible Dunveganoceras. Two specimens of $B$. orbiculatum from locality 22871 were illustrated by Kennedy and Cobban (1976, pl. 1, figs. 3, 4). Other ammonites from locality 22871 include Moremanoceras, Hamites (pl. 11, fig. 2), Anisoceras, Scaphites, and small undescribed genera as well as a new species of Protacanthoceras described herein as $P$. alzadense.

The ammonite described by Stephenson $(1952$, p. 204 , pl. 49, fig. 3; pl. 51, figs. 8-11) as Mammites? bellsanus from the Templeton Member of the Woodbine Formation of north Texas is better assigned to Plesiacanthoceras. The species differs from $P$. wyomingense in having a more involute shell, a lesser excavated venter, and a weaker ornament.

Types.-USNM 220381, 388152-388169.

\section{Genus PROTACANTHOCERAS Spath, 1923}

Type species.-Ammonites bunburianus Sharpe, 1853.

Protacanthoceras was named by Spath (1923, p. 144) for a stock of small acanthoceratid ammonites. A generic diagnosis was not given. Four earlier named species were assigned to the genus by Spath; Protacanthoceras triseriale (J. de C. Sowerby), P. compressum (JukesBrowne), P. bunburianum (Sharpe), and P. hippocastanum (J. de C. Sowerby). The genus has been recently treated in detail by Wright and Kennedy (1980), who gave the following diagnosis:
Small. Adult at diameters of $15-50 \mathrm{~mm}$. Moderately involute, compressed to depressed, flat-sided or round-whorled, bearing primary and intercalated ribs, typically with prominent umbilical and inner ventrolateral tubercles and closely spaced clavate outer ventrolateral and siphonal tubercles; tuberculation declines as the end of the body chamber and the ribs become broad and flat. Dimorphic, microconchs generally less densely and more strongly ribbed than macroconchs, although both show essentially similar styles of ornament. In a few species some or all tuberculation except for the umbilical is suppressed during part or all of ontogeny. Suture simple, with broad bifid $L$ and smaller bifid $\mathrm{U}_{2}$. E/L larger, bifid; $\mathrm{L} \mathrm{U}_{2}$ small, simple. Auxiliaries may be pseudoceratitic.

Wright and Kennedy (1980, p. 70$)$ noted that Protacanthoceras ranges from the lower part of the middle Cenomanian to the middle of the upper Cenomanian. Most specimens have come from southern England, and a few have been found in France and Madagascar.

\section{Protacanthoceras hosei Cobban, n. sp.}

Plate 9, figures 1-47; text figures 12, 14

This small species has a body chamber ornamented by fairly coarse ribs and tubercles that persist to the aperture. Ribs are straight on small specimens and flexuous on larger ones. Clavate outer ventrolateral and siphonal tubercles are conspicuous on the body chamber. Early whorls may have a slight cunningtoniceratid aspect. The species is named for Richard $K$. Hose who collected the type lot while he was with the U.S. Geological Survey. Two forms of the species are distinguished, $P$. hosei hosei and $P$. hosei sheridanense, $\mathrm{n}$. subsp.

Protacanthoceras hosei hosei Cobban, n. subsp.

Plate 9, figures 1-27; text figure 12

This form of the species is characterized by its fairly slender whorls and by its flexuous ribbing. The type lot, from the Frontier Formation in northern Wyoming at locality 22804 (fig. 1), contains 25 specimens suitable for the determination of three or more of the following measurements; diameter, umbilicus, diameter at base of the body chamber, and number of umbilical and ventrolateral tubercles in half a whorl. Diameters at the base of the body chambers could be determined for 20 of the specimens; these measurements ranged from 10-16.6 mm (fig. 11). Five specimens have approximated terminal septa at diameters of $16.7,17.2,18.3$, 21.5 , and $22.2 \mathrm{~mm}$.

The holotype (USNM 388170) is a complete adult $20.5 \mathrm{~mm}$ in diameter with an umbilical diameter of $4.7 \mathrm{~mm}(0.23)$ (pl. 9, figs. 13-15). Most of the shell material is retained, and the base of the body chamber is not visible. The intercostal section of the body chamber is subquadrangular with flattened flanks, broadly rounded 


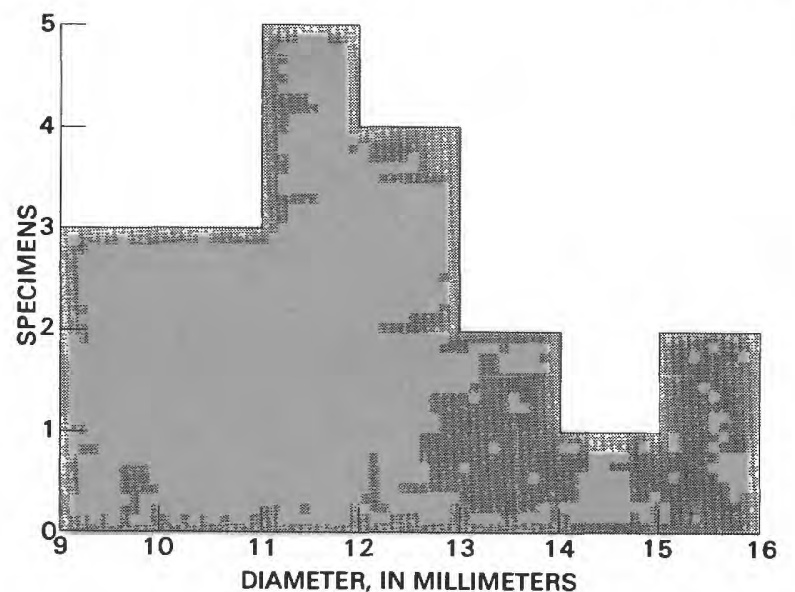

Figure 11.-Histogram showing diameters at the base of body chambers and number of specimens of Protacanthoceras hosei hosei Cobban, n. subsp., from the Frontier Formation at locality 22804 (fig. 1).

venter, rounded umbilical shoulder, and sloping umbilical wall. Ornament consists of narrow, slightly prorsiradiate ribs, umbilical bullae, nodate inner ventrolateral tubercles, and nodate to clavate outer ventrolateral and siphonal tubercles. Ornament on the first quarter of the outer whorl is somewhat reminiscent of Cunningtoniceras in that weaker secondary ribs are present, and these have smaller ventrolateral and siphonal tubercles. On the rest of the whorl, most ribs are equal in length and arise from bullae located on the umbilical shoulder. Each rib crosses the flank to a nodate inner ventrolateral tubercle. From there, the ribs broaden greatly and bend forward crossing the venter as broad, forward arched folds that support clavate outer ventrolateral and siphonal tubercles. The siphonal tubercles on the body chamber are asymmetric in that the adoral part is steep, and the adapical part is gently sloping. Ornament is strong on most of the body chamber, but just before the aperture, the ornament weakens a little, and, on the final rib, ventrolateral and siphonal tubercles become low and nodate.

The smallest whorls of the nominate subspecies examined are partly exposed on an unfigured paratype (USNM 388180). At a diameter of $2 \mathrm{~mm}$, the whorls are broader than high with broadly rounded venter and wellrounded flank. The whorls are smooth except for rows of small nodate ventrolateral tubercles that number 5 in half a whorl. These tubercles become the inner ventrolateral ones on larger whorls. Nodate outer ventrolateral and siphonal tubercles arise along with the ribs at some diameter less than $6 \mathrm{~mm}$ (pl. 9, fig. 1). At this size, the ribs cross the venter transversely and are usually bounded on their adoral side by a constriction (pl. 9, figs. $1,25)$. As the shell enlarges, ribs become more closely spaced, and constrictions disappear, and by a diameter of $8 \mathrm{~mm}$, outer ventrolateral and siphonal tubercles become asymmetrically clavate with the adoral side steepest. Umbilical bullae become distinct by a diameter of $15 \mathrm{~mm}$; they number 4-6 per half whorl at diameters of 15-20 mm and 5-9 at larger diameters. Ventrolateral and siphonal tubercles number 8-11 per half whorl without any obvious change in number with growth.

The apertural margin is usually incomplete or damaged. A large paratype from a limestone concretion at the top of the Soap Creek Bentonite Bed at locality D7370 in eastern Wyoming (fig. 1) has an aperture that features a ventral lappet (pl. 9, fig. 22).

The suture is typical of the genus (fig. 12). The external lobe $(\mathrm{E})$ is fairly broad; the lateral lobe $(\mathrm{L})$ is smaller and shallower than $\mathrm{E}$; and the $\mathrm{E} / \mathrm{L}$ saddle is broad and bifid.

Of the described species of Protacanthoceras, P. hosei most closely resembles $P$. tuberculatum Thomel (1972, p. 101, pl. 32, figs. 9-12). Both species have similar robust ornament, but $P$. tuberculatum has ribs of alternate lengths on the outer whorl, which is rarely seen on that whorl of $P$. hosei. In addition, $P$. tuberculatum has fewer ribs. Some slender individuals of $P$. hosei (pl. 9, figs. 19,20 ) recall slender specimens of $P$. bunburianum (Sharpe, 1853, p. 25, pl. 9, figs. 3a-c), but Sharpe's holotype shows a great weakening of the tuberculation on the younger part of the body chamber.

The type lot of $P$. hosei hosei came from sandy concretions in the upper part of the Frontier Formation at locality 22804 in north-central Wyoming (fig. 1). Hose (1955, p. 99-101) measured the Frontier Formation at this locality and listed the following important fossils names updated in square brackets at locality 22804: Inoceramus prefragilis Stephenson [I. rutherfordi Warren], Ostrea sp. [O. beloiti Logan], Borissiakoceras reesidei Morrow, B. n. sp., and Acanthoceras? amphibolum Morrow [Cunningtoniceras amphibolum fallense Cobban and Protacanthoceras hosei hosei Cobban].

Types.-Holotype USNM 388170, paratypes USNM 388171-388180.

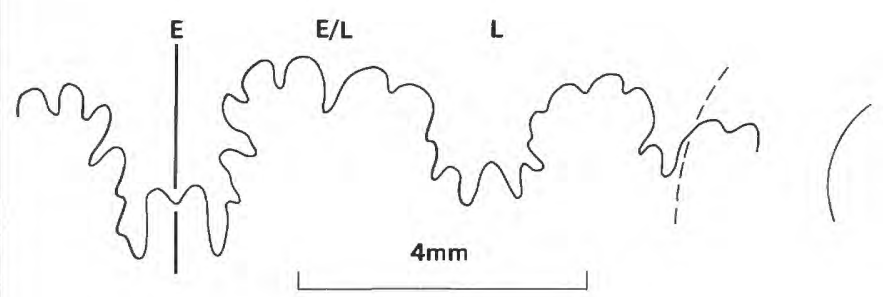

FIGURE 12.-Next to last external suture of Protacanthoceras hosei hosei Cobban, n. subsp., from the Frontier Formation at locality 22804 (fig. 1). Paratype USNM 388173 (pl. 9, figs. 6-9). 
Protacanthoceras hosei sheridanense Cobban, n. subsp. Plate 9, figures 28-47; text figure 14

This form is more robust and a little more sparsely ribbed than the nominate subspecies. The type lot, from locality D6933 (fig. 1) in Sheridan County in northern Wyoming, consists of 20 specimens suitable for measurements. Smaller specimens are present in the collection of ammonites from this locality, but these cannot be separated with certainty from very small inner whorls of the associated Cunningtoniceras amphibolum fallense. Diameters of the 20 specimens range from 5.7 to $16.4 \mathrm{~mm}$. All have parts of the body chambers, and diameters at the base of 18 could be determined. These diameters ranged from 3.6 to $14.7 \mathrm{~mm}$. Approximated terminal sutures were observed on only three specimens at diameters of $5.3,5.4$, and $14.1 \mathrm{~mm}$. Diameters at the base of the body chambers of the 17 specimens do not reveal any conspicuous grouping, which suggests that many of the specimens are immature (fig. 13).

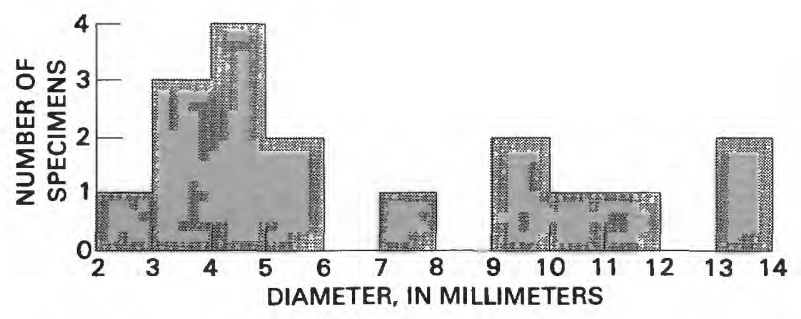

FIGURE 13.-Histogram showing diameters at the base of body chambers and number of specimens of Protacanthoceras hosei sheridanense Cobban, n. subsp., from the Frontier Formation at locality D6933 (fig. 1).

The holotype (USNM 388171) is a stout individual $16.4 \mathrm{~mm}$ in diameter with an umbilicus of $2.9 \mathrm{~mm}(0.17)$ (pl. 9, figs. 31-33). Its whorl section is quadrate about as high as wide with flat flanks, very broadly rounded venter, and narrowly rounded umbilical wall. The body chamber, which occupies the last half whorl, has a diameter at its base of about $10 \mathrm{~mm}$. Ribs on the last complete whorl number 12 and are rounded and mostly straight and rectiradiate on the flanks. Most arise from bullate to nodate umbilical tubercles located on the umbilical shoulder. Each rib rises into a prominent nodate to clavate inner ventrolateral tubercle. From this tubercle the rib broadens on crossing the venter, where it supports a conspicuous clavate outer ventrolateral tubercle and a similar-sized siphonal clavus. These clavate tubercles are asymmetric with the forward side steepest. Ribs cross the venter transversely on the phragmocone, but on the body chamber, the ribs become increasingly projected forward as they approach the aperture. At one place the venter is a little pathologic owing to the fusion of two of the outer ventrolateral tubercles into a single clavus as well as the fusion of the two adjacent siphonal tubercles into a single clavus. The aperture is not preserved, but the great reduction in size of the last inner ventrolateral tubercle suggests that very little of the body chamber is missing.

The 20 specimens from locality D6933 have 6-10 ventrolateral tubercles per half whorl, averaging 7.3. On the smallest whorls observed, tubercles are nodate and are located on low, narrow ribs well separated by smooth areas (pl. 9, figs. 41, 42). An occasional individual may have a weak rib on the venter between two stronger tuberculated ribs (pl. 9, fig. 39). As the whorls enlarge, the ventral tubercles become clavate and more uniformly spaced (pl. 9, figs. 30, 33, 45).

Only bits of the suture are visible on the holotype. Most of the external suture of a very small paratype (USNM 388188) that has the last four septa approximated is shown in figure 14. The suture is as simple as that of the nominate subspecies. Protacanthoceras asgeirri Wright and Kennedy (1980, text fig. 47) has a similar suture.

The type lot of Protacanthoceras hosei sheridanense came from limestone concretions that formed along the Soap Creek Bentonite Bed in the upper part of the Frontier Formation at locality D6933 near the northern boundary of Wyoming (fig. 1). Associated fossils include Cunningtoniceras amphibolum fallense, Borissiakoceras reesidei Moreman, Inoceramus rutherfordi Warren, and Ostrea beloiti Logan.

Types.-Holotype USNM 388181, paratypes USNM 388182-388188.

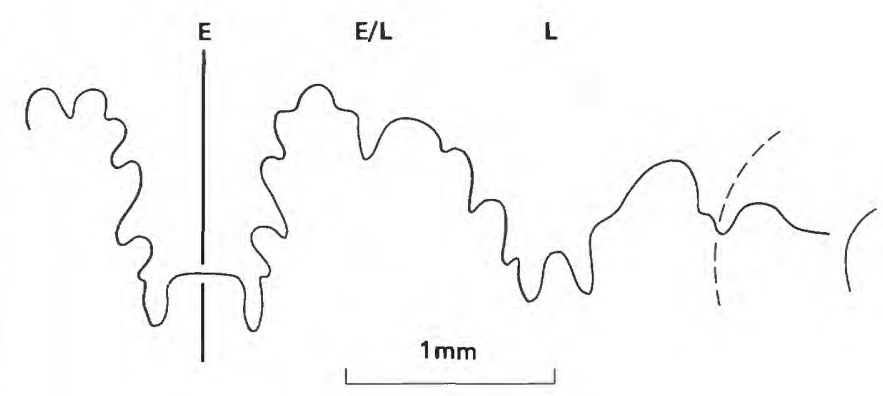

FIGURE 14.-Fourth from last external suture of a small paratype (USNM 388188) of Protacanthoceras hosei sheridanense Cobban, n. subsp., from a limestone concretion in the Soap Creek Bentonite Bed at locality D6933 (fig. 1). 
Protacanthoceras vetula Cobban, n. sp.

Plate 10, figures 1-28; text figure 16

Characteristic features of this new species include its robust shell and its nodate tubercles. Early whorls have constrictions like those of Protacanthoceras hosei.

The type lot is from limestone concretions in the upper part of the Belle Fourche Shale at locality D5900 on Old Woman anticline southwest of the Black Hills in eastern Wyoming (fig. 1). The species name vetula is Latin for old woman.

Twenty-eight specimens from locality D5900 are preserved well enough for measurements of the diameters of the shell, umbilicus, and base of the body chamber. These specimens range in size from 8.0 to $16.8 \mathrm{~mm}$. Diameters at the base of the body chambers range from 6.4 to 12.4 (fig. 15). Seven specimens have crowded septa at the end of the phragmocone at diameters of $8.6,8.9,9.0,9.0,10.0,10.2$, and $10.6 \mathrm{~mm}$. All specimens are involute with umbilical ratios of 0.12-0.19. Body chambers are about as high as wide or a little broader. Flanks are flattened, and venters are broadly rounded. Ornament on mature body chambers consists of weak umbilical bullae and strong forwardly arched

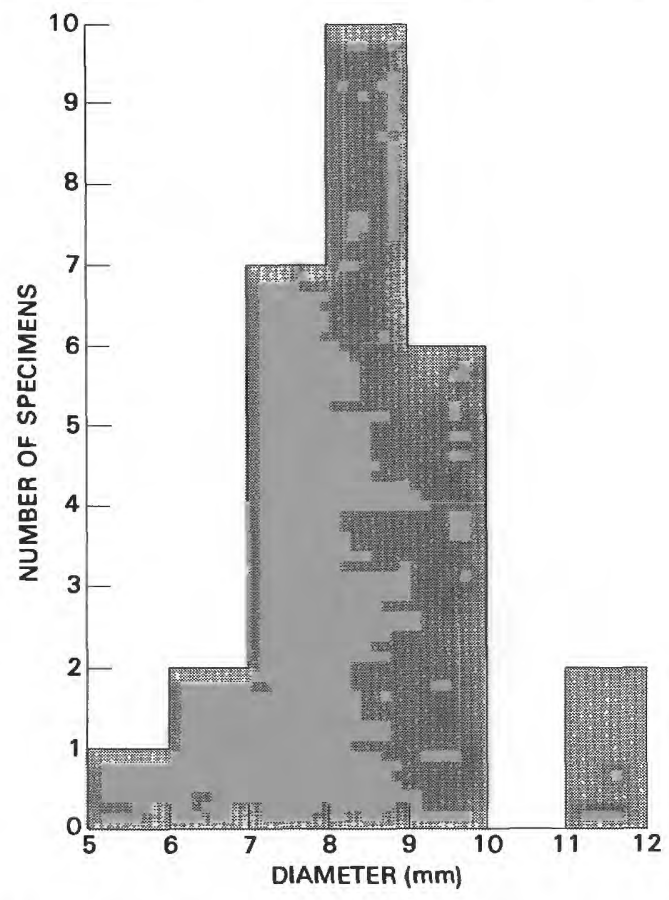

FIGURE 15.-Histogram showing diameters at the base of body chambers and the number of specimens of Protacanthoceras vetula Cobban, $\mathrm{n}$. sp., from the Belle Fourche Shale at locality D5900 (fig. 1).

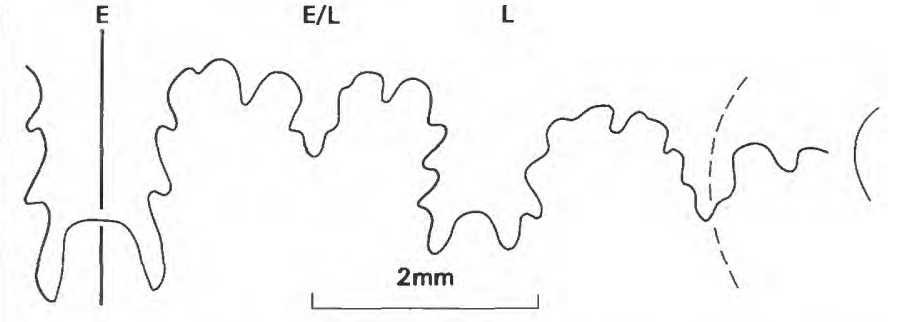

Figure 16.-Last external suture of Protacanthoceras vetula Cobban, n. sp., from the Belle Fourche Shale at locality D5900 (fig. 1). Holotype USNM 388189 (pl. 10, figs. 14-17).

ventral ribs that bear small inner and outer ventrolateral and siphonal tubercles. These tubercles number 5-13 in half a whorl, averaging 9 . Inner whorls are ornamented by narrow tuberculate ribs that number 5 or 6 in half a whorl. These ribs begin on the outer part of the flank and cross the venter transversely at first and with forward arching later. Each rib bears small nodate inner and outer ventrolateral and siphonal tubercles, which are about equal in size and spacing. A conspicuous constriction bounds the adoral side of the rib (pl. 10, figs. $3,7,18,23,24,28)$. The venter between the constriction and the next rib may be smooth (pl. 10, figs. 3,28 ) or it may contain a faint nontuberculate rib (pl. 10, fig. 15).

The holotype (USNM 388189) is a complete adult $15.5 \mathrm{~mm}$ in diameter with an umbilicus of $2.0 \mathrm{~mm}(0.13)$ (pl. 10, figs. 14-17). About two-thirds of the outer whorl is body chamber. Two crowded septa mark the end of the phragmocone. The venter on the last quarter whorl of the phragmocone is crossed by five forwardly arched tuberculate ribs that are bounded on their adoral side by narrow shallow constrictions. Under very oblique lighting, a faint nontuberculate rib can be detected in the area separating the constriction and the next tuberculate rib. This type of ornament persists on to the older part of the body chamber, but on the younger part, the faint rib rapidly increases in height and becomes tuberculate. Ribbing and tuberculation are abruptly reduced near the aperture, which is marked by a ventral lappet (pl. 10, fig. 14). The suture of the holotype (fig. 16) is typical of the genus. In its details, the suture resembles that of a paratype of $P$. tuberculatum mite Wright and Kennedy (1980, text fig. 3A).

The early whorls of $P$. vetula that have widely spaced narrow tuberculate ventral ribs resemble similar early whorls of $P$. asgeirri Wright and Kennedy (1980, figs. 20, 21), P. arkelli arkelli Wright and Kennedy (1980, fig. 24), and P. tuberculatum Thomel as figured by Wright and Kennedy (1980, fig. 28). In addition, the early whorls 
of $P$. arkelli arkelli have constrictions. Protacanthoceras vetula, however, is much smaller and more involute than the European species and has smoother flanks.

The type lot was collected from limestone concretions near the top of the Belle Fourche Shale $3.6 \mathrm{~m}(12 \mathrm{ft})$ below the bentonite marker bed at locality D5900 (fig. 1). Associated fossils include Inoceramus arvanus Stephenson, Ostrea beloiti Logan, Cunningtoniceras amphibolum amphibolum (Morrow), Tarrantoceras sellardsi (Adkins), Borissiakoceras orbiculatum Stephenson, and a juvenile desmoceratid ammonite.

Types.-Holotype USNM 388189, paratypes USNM 388190-388197.

\section{Protacanthoceras alzadense Cobban, n. sp.}

Plate 10, figures 29-47; text figure 18

This species differs from Protacanthoceras hosei in its smaller size, in its smaller umbilicus, and in its weaker ornament. The type lot, from limestone concretions in the Belle Fourche Shale at locality 22871, near Alzada, Mont. (fig. 1), contains 30 specimens suitable for measurements of the base of the body chambers. These measurements range from 5.2 to $9.4 \mathrm{~mm}$ (fig. 17).

The holotype (USNM 388198) is a small but complete internal mold $11.6 \mathrm{~mm}$ in diameter that has an umbilicus of $1.3 \mathrm{~mm}(0.11)$ (pl. 10, figs. 29-32). The body chamber,

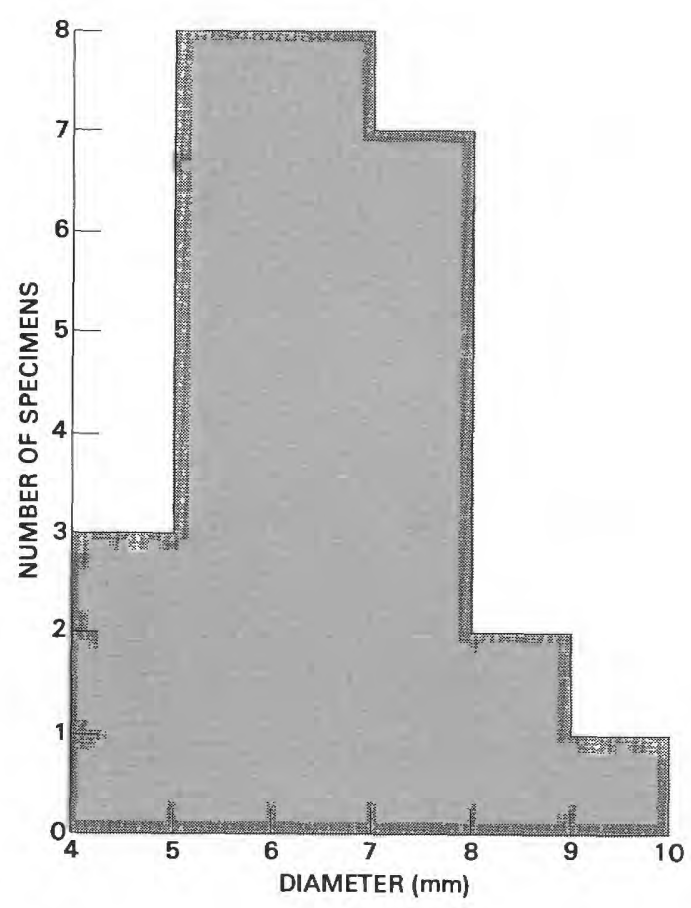

FIGURE 17-Histogram showing diameters at the base of body chambers and the number of specimens of Protacanthoceras alzadense Cobban, n. sp., from the Belle Fourche Shale at locality 22871 (fig. 1).

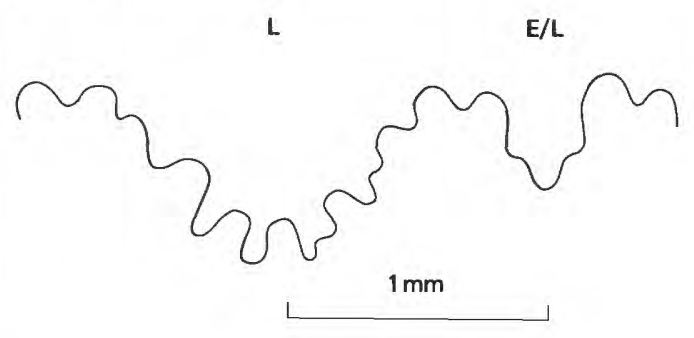

FIGURE 18.-Part of the penultimate external suture of the holotype (USNM 388198) of Protacanthoceras alzadense Cobban, n. sp., from the Belle Fourche Shale at USGS Mesozoic locality 22871 (fig. 1).

which occupies about two-thirds of a whorl, has a diameter of $5.6 \mathrm{~mm}$ at its base. Cross section of the outer septate whorl is broader than high with broadly rounded venter, slightly flattened flanks, well rounded umbilical shoulder, and steep umbilical wall. Cross section of the body chamber is more quadrate with flatter flanks and narrower, but flattened venter. Ornament on the younger part of the outer septate whorl consists of small, pointed, nodate inner ventrolateral tubercles and similar sized but weaker outer ones that number 6 or 7 per half whorl. In addition to these two rows of tubercles, ribs are present on the body chamber. Each rib begins at the umbilical shoulder, crosses the flank a little prorsiradially to the inner ventrolateral tubercle, and then becomes stronger and bends forward a little more to the outer tubercle. Each rib then becomes weaker and broader as it crosses the venter transversely to connect opposite outer ventrolateral tubercles. A very low clavate siphonal tubercle is present on each of these ribs. On the older two-thirds of the body chamber, inner and outer ventrolateral tubercles are nodate, but on the younger third, the inner ones weaken and disappear, and the outer ones become a little clavate and persist to the aperture. The aperture is normal and lacks constrictions and extensions.

The last two septa of the holotype are approximated. A complete external suture is not exposed. $\mathrm{E} / \mathrm{L}$ is broad and symmetrically divided by a deep spade-shaped lobe. $\mathrm{L}$ is narrower than $\mathrm{E} / \mathrm{L}$ and divided by several shallow indentations (fig. 18). The general configuration and simplicity is much like the suture of Protacanthoceras proteus Wright and Kennedy (1980, text fig. 57A).

The smallest whorls examined have diameters of 6.2 and $6.5 \mathrm{~mm}$. Ornament on the smaller of these specimens (unfigured paratype USNM 388204) consists of weak rectiradiate ribs that begin at the umbilical shoulder and trend straight across the flank, where they rise into conspicuous pointed, nodate inner ventrolateral tubercles. From these tubercles, a weak rib crosses the venter transversely and supports weak nodate outer ventrolateral tubercles and slightly smaller nodate to somewhat clavate 
siphonal tubercles. There are 6 of these tuberculate ribs in half a whorl. Interspaces between the ribs are several times wider than the ribs. The other specimen (paratype USNM 388201) differs in that ribs are of alternate lengths, and the longer rise into more conspicuous inner ventrolateral tubercles (pl. 10, figs. 39, 40). Only the longer ribs cross the venter, where they bear nodate outer ventrolateral and siphonal tubercles.

The specimens from locality 22871 were associated with Plesiacanthoceras wyomingense as well as the genera Moremanoceras, Borissiakoceras, Hamites, Anisoceras, Scaphites, and small undescribed genera. Inoceramus prefragilis Stephenson is also found at this locality.

Types.-Holotype USNM 388198, paratypes USNM 388199-388204.

\section{Protacanthoceras fisherense Cobban, n. sp.}

Plate 3, figures 1-6; text figure 19

This small species of Protacanthoceras has a strongly ribbed adult body chamber. The types are from the Frontier Formation at the head of Fisher Draw south of Kaycee in northern Wyoming (fig. 1, loc. 23459).

The holotype (USNM 388110 ) is a nearly complete adult $14.5 \mathrm{~mm}$ in diameter that has most of the body chamber preserved, but not the aperture (pl. 3, figs. 4-6). The umbilicus is very small with a diameter of only $1.1 \mathrm{~mm}$ and a ratio to the shell diameter of 0.08 . Its well rounded umbilical wall grades evenly into the more broadly rounded umbilical shoulder. The last half whorl of the phragmocone is visible; its cross section is wider than high with broadly rounded flanks and venter. Ornament on its older half consists of weak, narrow, tuberculate, rectiradiate ribs that arise at the umbilical shoulder and become strongest on crossing the venter. These ribs, which are fairly equal in length, support small bullate outer ventrolateral and siphonal tubercles. On the younger half of the phragmocone, ornament gradually strengthens. The body chamber, which occupies a full half whorl, is about as high as wide with flattened flanks and rounded venter. Ornament is conspicuous and consists of 11 narrow, flexuous ribs of about equal length and strength. Each rib bends forward at the ventrolateral shoulder and crosses the venter with slight forward arching. Low, bullate outer ventrolateral tubercles and equal-sized nodate siphonal tubercles are present on each rib. The suture (fig. 19) is comparable to other species of the genus. The lateral lobe $(\mathrm{L})$ is rather deeply bifid and narrower than the bifid E/L saddle.

A robust paratype (USNM 388111), from the same locality as the holotype, has small nodate to bullate inner ventrolateral tubercles on the outer whorl of the phragmocone (pl. 3, figs. 1-3). These tubercles weaken and gradually disappear on the body chamber. Like the holotype, the incomplete body chamber of the paratype occupies a full half whorl and is ornamented by 11 strong ribs that arch forward on crossing the venter. In addition to the weak inner ventrolateral tubercles on the older part, the ribs bear low, blunt, bullate outer ventrolateral tubercles and low, blunt, nodate siphonal tubercles.

Protacanthoceras fisherense is represented by only a few specimens, all from locality 23459 (fig. 1), where it occurs with Acanthoceras muldoonense Cobban and Scott. The conspicuous ribbing on the adult body chamber easily distinguishes $P$. fisherense from other species of the genus.

Types.-Holotype USNM 388110, paratype USNM 388111.

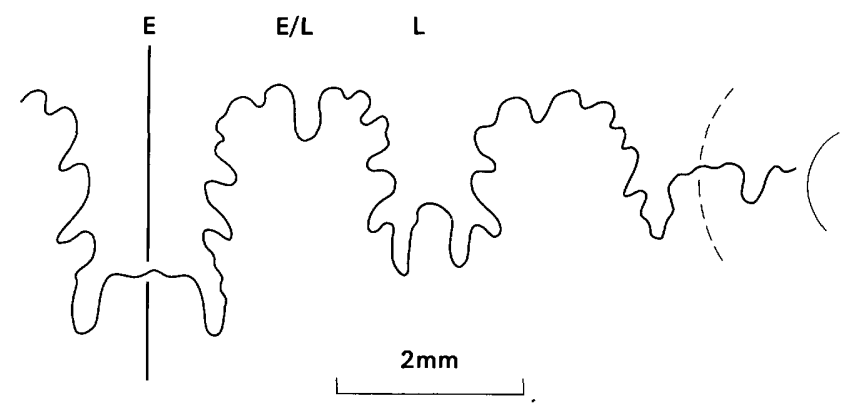

Figure 19.-Third from last external suture of the holotype (USNM 388110) of Protacanthoceras fisherense Cobban, n. sp., from the Frontier Formation at USGS Mesozoic locality 23459 (fig. 1).

\section{ZONATION OF ACANTHOCERATID AMMONITES}

That Plesiacanthoceras wyomingense occurs in rocks above those containing Cunningtoniceras amphibolum has been known since 1951 (Cobban, 1951, fig. 2), when the former was referred to as Acanthoceras? n. sp. and the latter as Acanthoceras? amphibolum. In the Pueblo area of Colorado, A. muldoonense was found below $C$. amphibolum (Cobban and Scott, 1972, p. 26-30, table 4).

Stratigraphic studies and additional collections of fossils made in the early 1970's revealed that the species referred to as $A$. amphibolum consists of two forms, an older one that has more siphonal and outer ventrolateral tubercles on the venter of the inner whorls than inner ventrolateral ones, and a younger one that tends to have equal numbers of tubercles. The older form was typical of Acanthoceras alvaradoense Moreman (1942, p. 205, pl. 32, fig. 6; text fig. $2 O, T$ ), a species described from the basal part of the Eagle Ford Group of Texas. The 
younger form was thought to be $A$. amphibolum s.s. Western Interior specimens were assigned to one or the other of these, and two zones were recognized, an older one of $A$. alvaradoense and a younger one of $A$. amphibolum (for example, Merewether and Cobban, 1972, table 1; Cobban and Scott, 1972, p. 33; Obradovich and Cobban, 1975, table 1). Because differences in the adult body chambers of $A$. amphibolum and $A$. alvaradoense cannot be distinguished, the two forms have recently been treated as one species, $A$. amphibolum, with $A$. alvaradoense considered as a subspecies of it (Cobban and Hook, 1983a, table 1; Cobban, 1984a). A zone of A. amphibolum was recognized with subzones of $A$. amphibolum alvaradoense and $A$. amphibolum amphibolum. The present investigation revealed that the type specimens of Morrow's A. amphibolum as well as other specimens from central Kansas have multiplication of ribs and tubercles on the venter of the inner whorls like that of Moreman's A. alvaradoense and that all these specimens should be more properly assigned to Cunningtoniceras. Inasmuch as the Acanthoceras amphibolum alvaradoense of recent reports is the same as $A$. amphibolum s.s., a new name is needed for the late form of the species. Cunningtoniceras amphibolum fallense is proposed herein for it.

Acanthoceras bellense Adkins has not been previously considered in the ammonite zonation of the Western Interior. This species is known from a very limited area near Osage, Wyo., on the west flank of the Black Hills (fig. 1, locs. D5869, D8841). The position of this fossil in the middle Cenomanian acanthoceratid sequence is not clear. At locality D5869, $A$. bellense occurs with Calycoceras (Gentoniceras) leonense (Adkins) $9.1 \mathrm{~m}$ (30 ft) above a bed of dusky-red ferruginuous concretions that contains Exogyra columbella Meek, a bivalve that may be restricted to the middle Cenomanian zone of Calycoceras (Conlinoceras) tarrantense (Adkins) (Cobban, 1977, table 2). Cunningtoniceras amphibolum occurs at locality D5869 $27.4 \mathrm{~m}(90 \mathrm{ft})$ above $A$. bellense. Near Pueblo, Colo., Calycoceras (Conlinoceras) gilberti Cobban and Scott, a close relative of $C$. tarrantense and probably of the same age, occurs in ferruginous concretions about a meter below the lowest occurrence of Acanthoceras muldoonense (Cobban and Scott, 1972, p. 7). It seems likely that $A$. bellense lies some place between the zones of $A$. muldoonense and Cunningtoniceras amphibolum.

The middle Cenomanian acanthoceratid sequence in the Western Interior is probably as follows:

$\begin{array}{ll}\text { Plesiacanthoceras wyomingense } & \begin{array}{l}\text { (at top) } \\ \text { Cunningtoniceras amphibolum }\end{array}\left\{\begin{array}{l}\text { C. amphibolum fallense } \\ \text { C. amphibolum amphibolum }\end{array}\right.\end{array}$

Acanthoceras bellense

Acanthoceras muldoonense

Calycoceras (Conlinoceras) tarrantense (at bottom)

\section{REFERENCES CITED}

Adkins, W. S., 1928, Handbook of Texas Cretaceous fossils: Texas University Bulletin 2838, 385 p., 37 pls.

Adkins, W. S., and Lozo, F. E., Jr., 1951, Stratigraphy of the Woodbine and Eagle Ford, Waco area, Texas, in Lozo, F. E., Jr., ed., The Woodbine and adjacent strata of the Waco area of central Texas: Fondren Science Series, no. 4, p. 101-164, pls. 1-6.

Cobban, W. A., 1951, Colorado shale of central and northwestern Montana and equivalent rocks of Black Hills: American Association of Petroleum Geologists Bulletin, v. 35, no. 10, p. 2170-2198.

1953, Cenomanian ammonite fauna from the Mosby sandstone of central Montana: U.S. Geological Survey Professional Paper 243-D, p. 45-55, pls. 6-12.

1971, New and little-known ammonites from the Upper Cretaceous (Cenomanian and Turonian) of the Western Interior of the United States: U.S. Geological Survey Professional Paper 699,24 p., 18 pls.

1975, The Upper Cretaceous ammonite Calycoceras naviculare (Mantell) in Arizona: Plateau, v. 47, no. 3, p. 109-112.

1977, Characteristic marine molluscan fossils from the Dakota Sandstone and intertongued Mancos Shale, west-central New Mexico: U.S. Geological Survey Professional Paper 1009, 30 p., 21 pls. 1983, Molluscan fossil record from the northeastern part of the Upper Cretaceous seaway, Western Interior, in Cobban, W. A., and Merewether, E. A., Stratigraphy and paleontology of midCretaceous rocks in Minnesota and contiguous areas: U.S. Geological Survey Professional Paper 1253-A, p. 1-25, 15 pls.

1984a, Mid-Cretaceous ammonite zones, western interior, United States: Bulletin of the Geological Society of Denmark, v. 33, pt. 1-2, p. 71-89.

1984b, Molluscan record from a mid-Cretaceous borehole in Weston County, Wyoming: U.S. Geological Survey Professional Paper 1271, 24 p., 5 pls.

Cobban, W. A., and Hook, S. C., 1979 [1980], Collignoniceras woollgari woollgari (Mantell) ammonite fauna from Upper Cretaceous of Western Interior, United States: New Mexico Bureau of Mines and Mineral Resources Memoir 37, 51 p., 12 pls.

1983a, Mid-Cretaceous (Turonian) ammonite fauna from Fence Lake area of west-central New Mexico: New Mexico Bureau of Mines and Mineral Resources Memoir 41, 50 p., 14 pls.

1983b, Pseudaspidoceras pseudonodosoides (Choffat)-Common Upper Cretaceous guide fossil in southwest New Mexico: New Mexico Bureau of Mines and Mineral Resources Annual Report 1981-82, p. $37-40$.

Cobban, W. A., and Scott, G. R., 1972 [1973], Stratigraphy and ammonite fauna of the Graneros Shale and Greenhorn Limestone near Pueblo, Colorado: U.S. Geological Survey Professional Paper 645, 108 p., 39 pls.

Collignon, Maurice, 1937, Ammonites cénomaniennes du sud-ouest de Madagascar: Madagascar, Service Mines, Annales Géologique, no. 8, p. 31-69, pls. 1-11.

Crick, G. C., 1907, The Cephalopoda from the deposit at the north end of False Bay, Zululand, Chapter 1 of Cretaceous fossils of Natal, Part 3 of Anderson, William, Third and final report of the Geological Survey of Natal and Zululand: London, West, Newman and Co., p. 161-234, pls. 10-15.

Furon, Raymond, 1935, Le Crétacé et le Tertiaire du Sahara soudanais (Soudan, Niger, Tchad): Muséum National Histoire Naturelle Archives, 6th ser., v. 13, p. 1-96, pls. 1-7.

Grossouvre, Albert de, 1893 [1894], Les ammonites de la craie supérieure, Pt. 2, Paléontologie, of Recherches sur la craie supérieure: Carte Géologique Détaillée de la France Mémoires, 264 p., 39 pls. 
Haas, Otto, 1949, Acanthoceratid Ammonoidea from near Greybull, Wyoming: American Museum of Natural History Bulletin, v. 93, art. 1,39 p., 15 pls.

1951, Supplementary notes on the ammonite genus Dunveganoceras: American Museum Novitates No. 1490, 21 p.

1963, Paracanthoceras wyomingense (Reagan) from the western interior of the United States and from Alberta (Ammonoidea): American Museum Novitates 2151, 19 p.

1964, Plesiacanthoceras, new name for Paracanthoceras Haas, 1963, non Furon, 1935: Journal of Paleontology, v. 38, no. 3, p. 610.

Hattin, D. E., 1965a, Stratigraphy of the Graneros Shale (Upper Cretaceous) in central Kansas: Geological Survey of Kansas Bulletin $178,83 \mathrm{p}$.

1965b, Upper Cretaceous stratigraphy, paleontology, and paleoecology of western Kansas, with a section on Pierre Shale, by W. A. Cobban: Geological Society of America Field Conference Guidebook, 78th Annual Meetings, 1965, 69 p.

1968, Plesiacanthoceras wyomingense (Reagan) from Graneros Shale and Greenhorn Limestone (Upper Cretaceous) of central Kansas: Journal of Paleontology, v. 42, no. 4, p. 1084-1090.

1975, Stratigraphy and depositional environment of Greenhorn Limestone (Upper Cretaceous) of Kansas: Kansas Geological Survey Bulletin 209, 128 p., 10 pls.

1977, Upper Cretaceous stratigraphy, paleontology and paleoecology of western Kansas, with a section on Pierre Shale, by W. A. Cobban: The Mountain Geologist, v. 14, nos. 3, 4, p. 175-218.

Hattin, D. E., and Siemers, C. T., 1978, Upper Cretaceous stratigraphy and depositional environments of western Kansas: Kansas Geological Survey, The University of Kansas Guidebook Series 3, $102 \mathrm{p}$.

Henderson, Junius, 1908, New species of Cretaceous invertebrates from northern Colorado: U.S. National Museum Proceedings, v. 34, no. 1611 , p. 259-264, pl. 13.

Hook, S. C., and Cobban, W. A., 1981, Late Greenhorn (mid-Cretaceous) discontinuity surfaces, southwest New Mexico: New Mexico Bureau of Mines and Mineral Resources Circular 180, p. 5-21, 3 pls. 1982, Spathites puercoensis (Herrick and Johnson)-Common Upper Cretaceous guide fossil in Rio Puerco valley, New Mexico: New Mexico Bureau of Mines and Mineral Resources Annual Report 1980-81: p. 36-39.

Hose, R. K., 1955 [1956], Geology of the Crazy Woman Creek area, Johnson County, Wyoming: U.S. Geological Survey Bulletin 1027-B, p. 33-118.

Hyatt, Alpheus, 1900, Cephalopoda, in Zittel, K. A. von, [1896-1900], Textbook of palaeontology: London, MacMillan and Company, p. 502-604.

1903, Pseudoceratites of the Cretaceous, edited by T. W. Stanton: U.S. Geological Survey Monograph 44, 351 p., 47 pls.

Jones, T. S., 1938, Geology of Sierra de la Peña and paleontology of the Indidura formation, Coahuila, Mexico: Geological Society of America Bulletin, v. 49, no. 1, p. 69-150, pls. 1-13.

Juignet, Pierre, and Kennedy, W. J., 1976, Faunes d'ammonites et biostratigraphie comparée du Cénomanien du nord-ouest de la France (Normandie) et du sud de l'Angleterre: Société Géologique de Normandie et Amis du Muséum du Havre, v. 63, no. 2, 193 p., $34 \mathrm{pls}$.

Kauffman, E. G., 1977, Illustrated guide to biostratigraphically important macrofossils, Western Interior basin, U.S.A.: The Mountain Geologist, v. 14, nos. 3-4, p. 225-274, 32 pls.

Kauffman, E. G., Cobban, W. A., and Eicher, D. L., 1976 [1978], Albian through lower Coniacian strata, biostratigraphy and principal events, Western Interior United States, in Mid-Cretaceous events, Uppsala-Nice symposiums, 1975-1976: Annales du Muséum d'Histoire Naturelle de Nice, v. 4, p. 23.1-23.52, 17 pls.
Kauffman, E. G., and Powell, J. D., 1977, Paleontology, in Kauffman, E. G., Hattin, D. E., and Powell, J. D., Stratigraphic, paleontologic, and paleoenvironmental analysis of the Upper Cretaceous rocks of Cimarron County, northwestern Oklahoma: Geological Society of America Memoir 149, p. 47-114, 12 pls.

Kennedy, W. J., 1971, Cenomanian ammonites from southern England: Palaeontological Association of London Special Papers in Palaeontology 8, 133 p., 64 pls.

Kennedy, W. J., and Cobban, W. A., 1976, Aspects of ammonite biology, biogeography, and biostratigraphy: Palaeontological Association of London Special Papers in Palaeontology 17, 94 p., 11 pls.

Knechtel, M. M., and Patterson, S. H., 1952, Bentonite deposits of the Yellowtail district, Montana and Wyoming: U.S. Geological Survey Circular 150, $7 \mathrm{p}$.

1955, Bentonite deposits of the northern Black Hills district, Montana, Wyoming, and South Dakota: U.S. Geological Survey Mineral Investigations Field Studies Map MF-36, 2 sheets, scale $1: 48,000$, with sections and text.

1956, Bentonite deposits in marine Cretaceous formations, Hardin district, Montana and Wyoming: U.S. Geological Survey Bulletin 1023, 116 p., illus.

1962, Bentonite deposits of the northern Black Hills district, Wyoming, Montana, and South Dakota: U.S. Geological Survey Bulletin 1082-M, p. 893-1030.

Matsumoto, Tatsuro, 1960, On some type ammonites from the Gulf Coast Cretaceous: Kyushu University Faculty of Science, Science Reports, Geology, v. 5, no. 1, p. 36-49 [in Japanese].

Matsumoto, Tatsuro, Muramoto, Tatsuo, and Takahashi, Takemi, 1969, Selected acanthoceratids from Hokkaido (Studies of the Cretaceous ammonites from Hokkaido and Saghalien-XIX): Kyushu University Faculty of Science Memoirs, Ser. D, Geology, v. 19, no. 2, p. 251-296, pls. 25-38.

Matsumoto, Tatsuro, and Obata, Ikuwo, 1966, An acanthoceratid ammonite from Sakhalin: Bulletin of the National Science Museum, v. 9 , no. 1 , p. $43-52,4$ pls.

Matsunoto, Tatsuro, Saita, Rinji, and Fukada, Atsuo, 1957, Some acanthoceratids from Hokkaido (Studies on the Cretaceous ammonites from Hokkaido and Saghalien-XI): Kyushu University Faculty of Science Memoirs, Ser. D, Geology, v. 6, no. 1, p. 1-45, 18 pls.

Merewether, E. A., and Cobban, W. A., 1972, Unconformities within the Frontier Formation, northwestern Carbon County, Wyoming, in Geological Survey Research 1972: U.S. Geological Survey Professional Paper 800-D, p. D57-D66.

Merewether, E. A., Cobban, W. A., and Cavanaugh, E. T., 1979, Frontier Formation and equivalent rocks in eastern Wyoming: The Mountaim Geologist, v. 16 , no. 3, p. $67-101,4$ pls.

Moore, R. C., 1949, Meaning of facies, in Longwell, C. R., Sedimentary facies in geologic history: Geological Society of America Memoir 39, p. 1-39.

Moreman, W. L., 1942, Paleontology of the Eagle Ford group of north and central Texas: Journal of Paleontology, v. 16, no. 2, p. 192-220, pls. 31-34.

Morrow, A. L., 1935, Cephalopods from the Upper Cretaceous of Kansas: Journal of Paleontology, v. 9, no. 6, p. 463-473, pls. 49-53.

Neumayr, Melchior, 1875, Die Ammoniten der Kreide und die Systematik der Ammonitiden: Zeitschrift der Deutschen Geologischen Gesellschaft, v. 27, p. 854-892.

Obradovich, J. D., and Cobban, W. A., 1975, A time-scale for the Late Cretaceous of the western interior of North America, in Caldwell, W. G. E., ed., The Cretaceous System in the western interior of North America: Geological Association Canada Special Paper 13, p. 31-54.

Reagan, A. B., 1924, Cretacic Mollusca of Pacific slope: Pan-American Geologist, v. 41, p. 179-190, pls. 18-21. 
Reeside, J. B., Jr., 1927, An Acanthoceras rhotomagense fauna in the Cretaceous of the Western Interior: Journal of the Washington Academy of Sciences, v. 17, no. 17, p. 453, 454.

Robinson, C. S., Mapel, W. J., and Bergendahl, M. H., 1964, Stratigraphy and structure of the northern and western flanks of the Black Hills uplift, Wyoming, Montana, and South Dakota: U.S. Geological Survey Professional Paper 404, 134 p.

Sharpe, Daniel, 1853-56, Description of the fossil remains of Mollusca found in the Chalk of England: Palaeontographical Society [Monograph], 68 p., 27 pls.; 1853, p. 1-26, pls. 1-10; 1854, p. 27-36, pls. 11-16 [1855]; 1856 , p. 37-68, pls. $17-27$ [1857].

Spath, L. F., 1923, On the ammonite horizons of the Gault and contiguous deposits, in Great Britain Geological Survey summary of progress for 1922: p. 139-149.

Stanton, T. W., 1893 [1894], The Colorado formation and its invertebrate fauna: U.S. Geological Survey Bulletin 106, 288 p., 45 pls.

Stephenson, L. W., 1952 [1953], Larger invertebrate fossils of the Woodbine formation (Cenomanian) of Texas: U.S. Geological Survey Professional Paper 242, 211 p., 58 pls.

1955, Basal Eagle Ford fauna (Cenomanian) in Johnson and Tarrant Counties, Texas: U.S. Geological Survey Professional Paper 274-C, p. 53-67, pls. 4-7.

Strain, W. S., 1976, New formation names in the Cretaceous at Cerro de Cristo Rey, Dona Ana County, New Mexico, Appendix 2, in Lovejoy, E. M. P., Geology of Cerro de Cristo Rey uplift, Chihuahua and New Mexico: New Mexico Bureau of Mines and Mineral Resources Memoir 31, p. 77-82.

Thomel, Gérard, 1972, Les Acanthoceratidae cénomaniens des chaines subalpines méridionales: Société Géologique France Mémoires, n. ser., v. 51, Mémoire 116, 204 p., 88 pls.

Warren, P. S., and Stelck, C. R., 1955, New Cenomanian ammonites from Alberta: Research Council of Alberta Report No. 70, p. 63-75, pls. 4-9.

White, C. A., 1877, Report upon the invertebrate fossils collected in portions of Nevada, Utah, Colorado, New Mexico, and Arizona, by parties of the expeditions of $1871,1872,1873$, and 1874: U.S. Geographical and Geological Explorations and Surveys West of the 100 th Merician, v. 4, pt. 1, Paleontology, 219 p., 21 pls.

Wright, C. W., 1957, Family Acanthoceratidae Hyatt, in Arkell, W. J., and others, Mesozoic Ammonoidea, in Moore, R. C., ed., Treatise on invertebrate paleontology, Part L, Mollusca 4: New York and Lawrence, Kansas, Geological Society of America and University of Kansas Press, p. L410-L417.

Wright, C. W., and Kennedy, W. J., 1980, Origin, evolution and systematics of the dwarf Acanthoceratid Protacanthoceras Spath, 1923 (Cretaceous Ammonoidea): Bulletin of the British Museum (Natural History), Geology series, v. 34, no. 2, p. 65-107. 


\section{INDEX}

[Italic page numbers indicate major references]

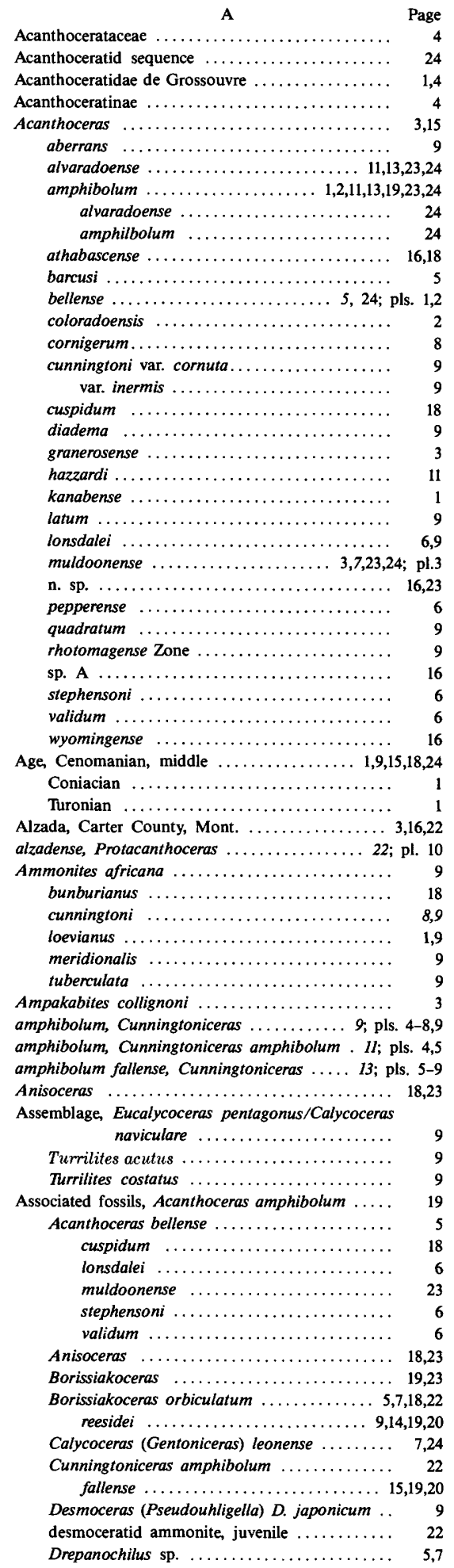

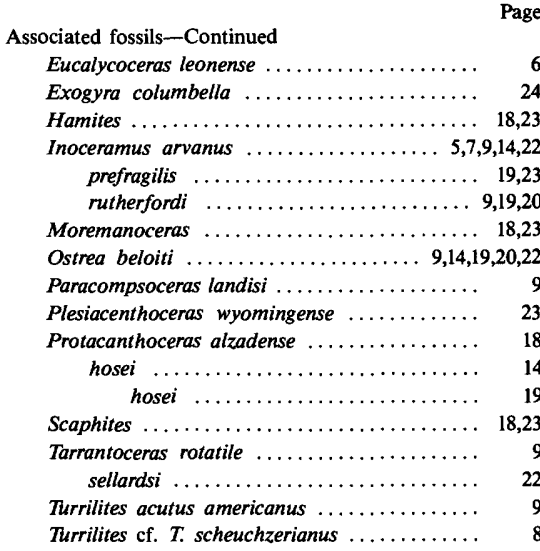

Bed F, Belle Fourche Shale $\ldots \ldots \ldots \ldots \ldots \ldots \ldots, 15$

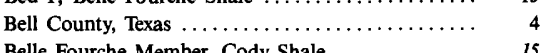
Belle Fourche Member, Cody Shale .......... 15

Belle Fourche Shale $\ldots \ldots \ldots \ldots \ldots \ldots \ldots \ldots, 1,4,13,22$ Alzada, Mont. ..................... 22

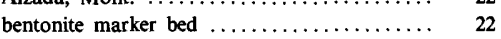

Black Hills $\ldots \ldots \ldots \ldots \ldots \ldots \ldots \ldots \ldots \ldots, 15,16,18$

upper part $\ldots \ldots \ldots \ldots \ldots \ldots \ldots \ldots \ldots \ldots, 21$

bellense, Acanthoceras ................ 5; pls. 1,2

Bentonite bed, Belle Fourche Shale ........... 15

Bentonite marker bed, Graneros Shale $\ldots \ldots \ldots \ldots$ 12,13

Big Horn County, Mont.

Bird Creek

Black Hills, Belle Fourche Shale $\ldots \ldots \ldots \ldots \ldots \ldots, 1,16,18$

west flank ....................4, 4, 12,13,14,24

Bluebonnet Member, Lake Waco Formation ..... 5

Boquillas Formation, New Mexico ............. 13

Borissiakoceras ........................ 23

n. sp. $\ldots \ldots \ldots \ldots \ldots \ldots \ldots \ldots \ldots \ldots \ldots \ldots \ldots \ldots \ldots, \quad 19$

orbiculatum $\ldots \ldots \ldots \ldots \ldots \ldots \ldots \ldots \ldots, 5,7,18,22$

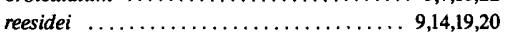

Buchiceras swallovi .....

bunburianus, Ammonites ..................... 18

\section{C}

Calycoceras .......................... 3

(Conlinoceras) gilberti ................ 3,24 tarrantense ....................... 24

(Gentoniceras) leonense ............ 4,7,24; pl. 1 naviculare $\ldots \ldots \ldots \ldots \ldots \ldots \ldots \ldots, 2$

Cenomanian $\ldots \ldots \ldots \ldots \ldots \ldots \ldots \ldots \ldots, 1$ middle $\ldots \ldots \ldots \ldots \ldots \ldots \ldots \ldots \ldots \ldots \ldots \ldots \ldots, 9,15,18,24$

Clay Mesa Tongue, Mancos Shale

Cody Shale, Soap Creek Bentonite Bed $\ldots \ldots \ldots \ldots$. IS

Collignoniceras woollgari

Coniacian

Crook County, Wyo.

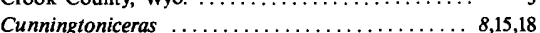

amphibolum ................ 9,22,23; pls. 4-8,9 amphibolum ................. 11; pls. 4,5 fallense .............. 13,19,20,24; pls. 5-9

cunningtoni, Ammonites ................. $\quad 8,9$

\section{D}

Definition of terms

Descriptions, systemic

Desmoceras (Psendouhligella) D. japonicum ........ 9

Drepanochilus sp. .................... 5,7

Dry Muddy Creek, Johnson County, Wyo. ........ 3

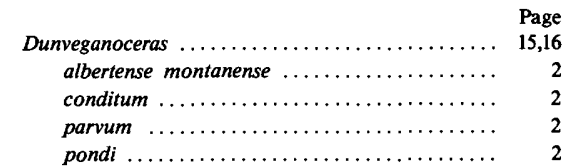

E

Eagle Ford Formation. . . . . . . . . . . . .

Eagle Ford Group $\ldots \ldots \ldots \ldots \ldots \ldots \ldots \ldots \ldots, \quad 4,23$

Ellsworth County, Kansas................. $\quad 3,12$

Elm Creek, Niobrara County, Wyo............ 3

England $\ldots \ldots \ldots \ldots \ldots \ldots \ldots \ldots \ldots \ldots, \quad 18$

Eucalycoceras leonense.................. 4,6

Eucalycoceras pentagonus/Calycoceras naviculare Assemblage Zone $\ldots \ldots \ldots \ldots \ldots \ldots$, 9

Euomphaloceras $\ldots \ldots \ldots \ldots \ldots \ldots \ldots \ldots, \quad \mathbf{3 , 9}$

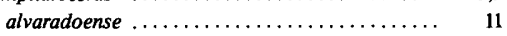

cunningtoni

euomphalum $\ldots \ldots \ldots \ldots \ldots \ldots \ldots \ldots$

(Kanabiceras) septemseriatum

Exogyra columbella ...................... 24

F

Fall County, South Dakota $\ldots \ldots \ldots \ldots \ldots \ldots \ldots$

Fisher Draw, Kaycee, Johnson County, Wyo ..... 3,23

fisherense, Protacanthoceras ................ 23;pl.3

Flag Member, Eagle Ford Fromation.......... 5

Formations, Belle Fourche Shale $\ldots \ldots 1,4,13,15,16,18,21,22$

$\begin{array}{lr}\text { Boquillas Formation } \ldots \ldots \ldots \ldots \ldots \ldots \ldots \ldots & 13 \\ \text { Cody Shale, Belle Fourche Member } \ldots \ldots \ldots \ldots & 15\end{array}$

Cody Shale, Belle Fourche Member ........ 15

Soap Creek Bentonite Bed........... 3,15,19

Eagle Ford Formation $\ldots \ldots \ldots \ldots \ldots \ldots \ldots, \quad 5,18$
Frontier Formation $\ldots \ldots \ldots \ldots \ldots, 1,2,7,8,14,16,18,19,23$ Soap Creek Bentonite Bed $\ldots \ldots \ldots \ldots \ldots, 20$

Graneros Shale, . . . . . . . . . . . 2,3,7,11,12,13 Thatcher Limestone Member......... 8,9

Greenhorn Limestone $\ldots \ldots \ldots \ldots \ldots \ldots \ldots \ldots .2,3,15$

Lake Waco Foundation............... 5

Lower Chalk..................... 9

Mancos Shale, Clay Mesa Tongue......... 13

Tarrant Formation ............ 5

Woodbine Formation, Templeton Member.... 5,18

Fossil localities..............................

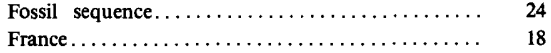

Frontier Formation $\ldots \ldots \ldots \ldots \ldots \ldots \ldots \ldots \ldots \ldots, 1,2,16,18$

Fisher Draw, Wyo. .................. 23

north-central Wyoming............... $7,8,14,18,19$

Soap Creek Bentonite Bed............. 20

G, $\mathrm{H}$

Gay Creek, Sheridan County, Wyo............ 3

Gentoniceras, Calycoceras leonense............ 4

Graneros Shale $\ldots \ldots \ldots \ldots \ldots \ldots \ldots \ldots \ldots \ldots, 2,3,7,12,13$

Thatcher Limestone Member $\ldots \ldots \ldots \ldots \ldots \ldots, 8,9$

upper part......................... 11

Greenhorn Limestone $\ldots \ldots \ldots \ldots \ldots \ldots \ldots \ldots \ldots, 2,3,15$

Hamites $\ldots \ldots \ldots \ldots \ldots \ldots \ldots \ldots \ldots \ldots \ldots \ldots, \quad 18,23$

hosei, Protacanthoceras .................. 18,231.9

sheridanense, Protacanthoceras........... 20;pl.9

Hot Springs, Fall River County, S. Dak........... 3

$$
\text { I, K }
$$

Inoceramus arvanus $\ldots \ldots \ldots \ldots \ldots, 5,7,9,14,22$ prefragilis $\ldots \ldots \ldots \ldots \ldots \ldots \ldots \ldots \ldots \ldots, 19,23$ prefragilis $\ldots \ldots \ldots \ldots \ldots \ldots \ldots \ldots \ldots \ldots \ldots \ldots \ldots \ldots \ldots \ldots \ldots \ldots \ldots \ldots, 9,19,23$
rutherfordi $\ldots \ldots \ldots \ldots \ldots \ldots$

Kanabiceras puebloense. 3

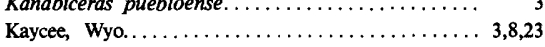




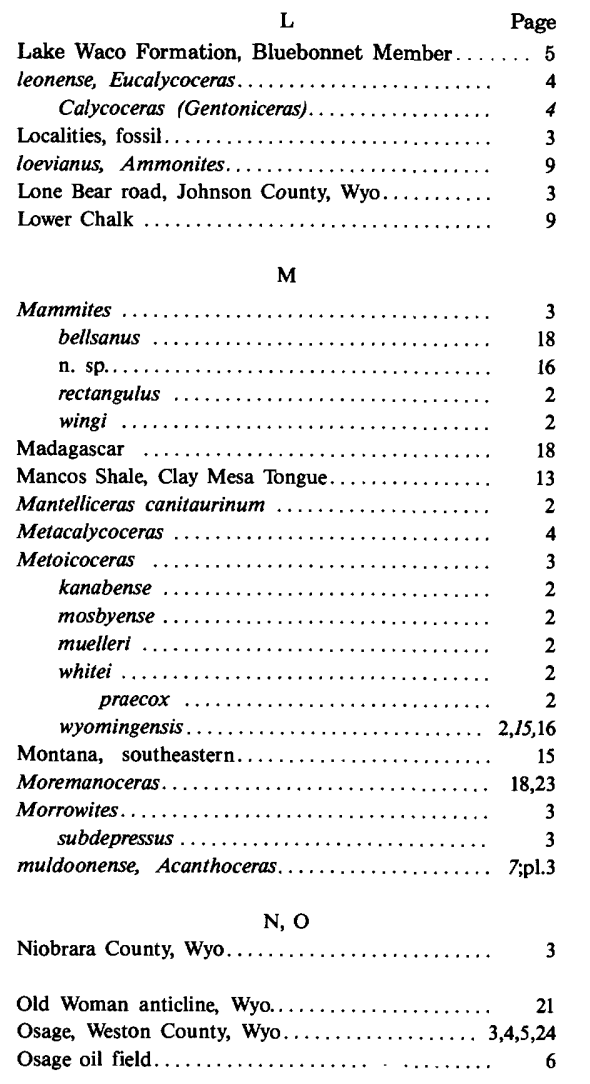

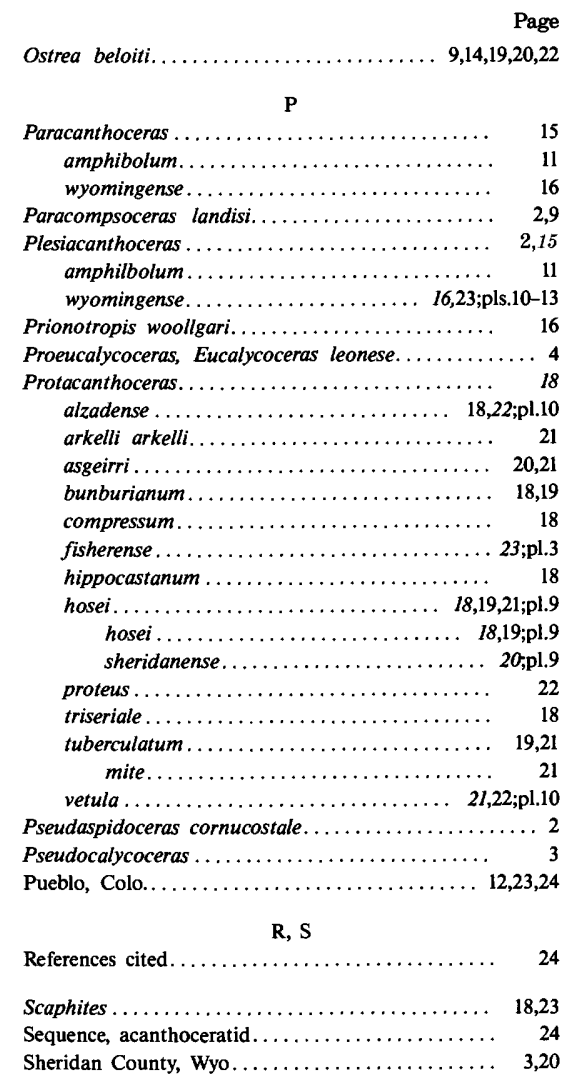

sheridanense, Protacanthoceras hosei........ 20;pl.9 Smokey Hill River, Kansas.................... 3,12

Soap Creek dome....................... 3

Soap Creek Bentonite Bed, Belle Fourche Member, Cody Shale $\ldots \ldots \ldots \ldots \ldots \ldots \ldots, 3,15,19$ Soap Creek Bentonite Bed, Frontier Formation...... 20 South Dakota, Belle Fourche Shale............ 13 Systemic descriptions

$\mathrm{T}$

Tarrant Formation $\ldots \ldots \ldots \ldots \ldots \ldots \ldots \ldots \ldots, 5$

Tarrantoceras........................... 3 rotatile .......................... 9 sellardsi............................... Templeton Member, Woodbine Formation........ 18 Terms defined $\ldots \ldots \ldots \ldots \ldots \ldots \ldots \ldots \ldots, \quad 3$ Thatcher Limestone Member, Graneros Shale...... 8,9 Time. See Age.

Turonian ...............................

Turrilites acutus americanus. ................. acutus Assemblage................... 9

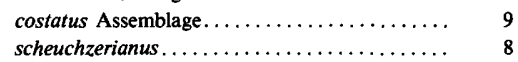

$\mathrm{V}, \mathrm{W}, \mathrm{Z}$

vetula, Protacanthoceras $\ldots \ldots \ldots \ldots \ldots \ldots . \ldots 21 ; \mathrm{pl} .10$

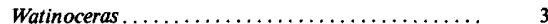

Wilson, Kansas. .

Woodbine Formation.................. 5,18

Wyoming, eastern, Belle Fourche Shale........ 15 west of Black Hills. . . . wyomingense, Plesiacanthoceras......... 16;pls.10-13 wyomingensis, Metoicoceras................ 15

Zone, Acanthoceras rhotomagense............. 9 Eucalycoceras pentagonus/Calycoceras naviculare 


\section{PLATES 1-13}

Contact photographs of the plates in this report are available, at cost, from the U.S. Geological Survey Photographic Library, Federal Center, Denver, Colorado 80225. 


\section{PLATE 1}

[All figures natural size. Arrows mark base of body chambers]

Figures 1-17. Calycoceras (Gentoniceras) leonense (Adkins) (p. 4).

From the Belle Fourche Shale at USGS Mesozoic locality D8841 (text fig. 1).

1, 2. Rear and side views of hypotype USNM 388087.

3-5. Front, rear, and side views of hypotype USNM 388088.

6-8. Front, side, and rear views of hypotype USNM 388089.

9-11. Front, side, and rear views of hypotype USNM 388090.

12, 13. Side and front views of hypotype USNM 388091.

14,15 . Rear and side views of hypotype USNM 388092.

16,17 . Rear and side views of a fragment of the largest specimen, hypotype USNM 388093.

18, 19. Acanthoceras bellense Adkins (p. 5).

Rear and side views of a plaster cast of the holotype from the basal part of the Eagle Ford Group in Bell County, Tex. 
U.S. GEOLOGICAL SURVEY

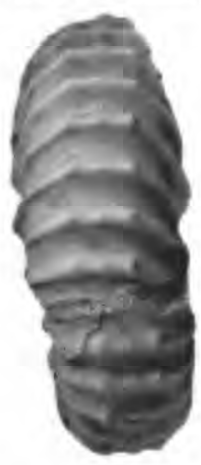

1

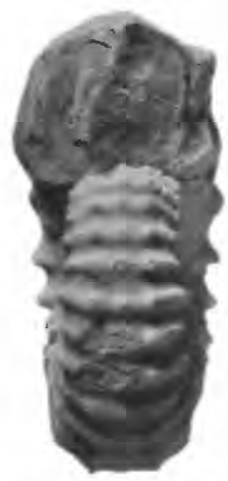

9

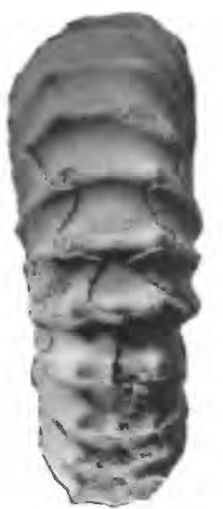

14
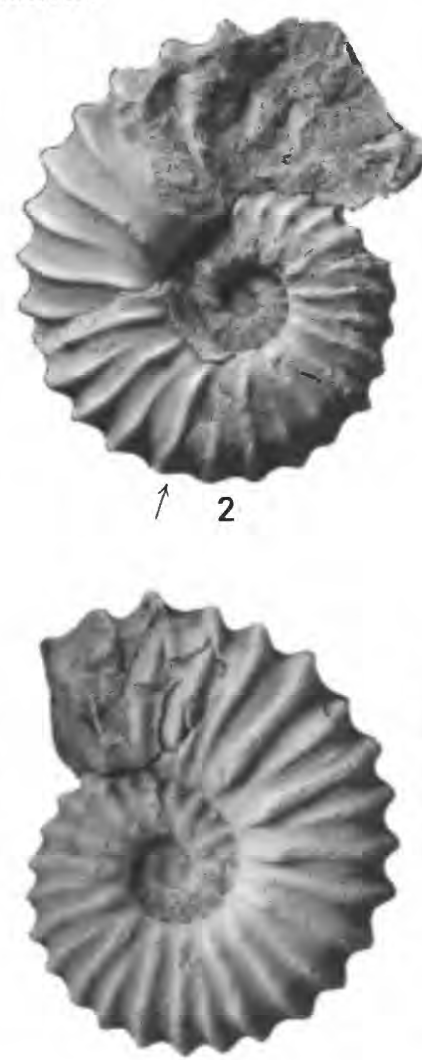

10

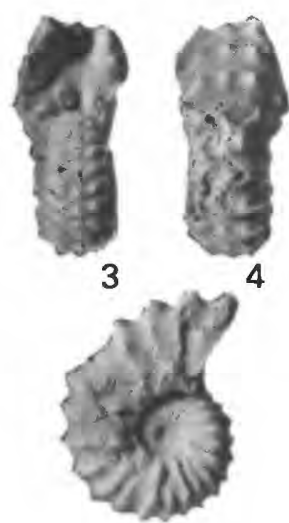

5

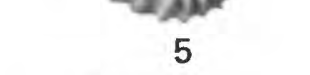

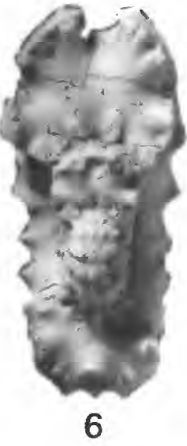

PROFESSIONAL PAPER 1445 PLATE 1
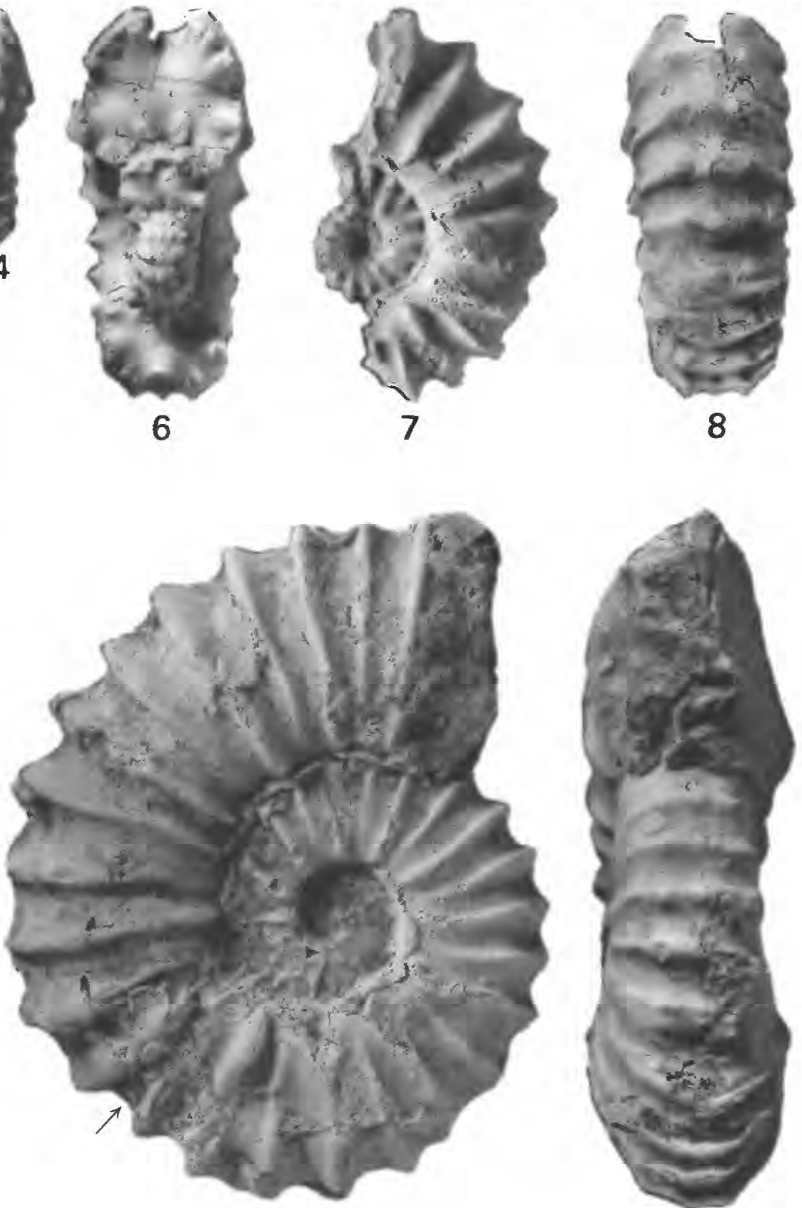

12
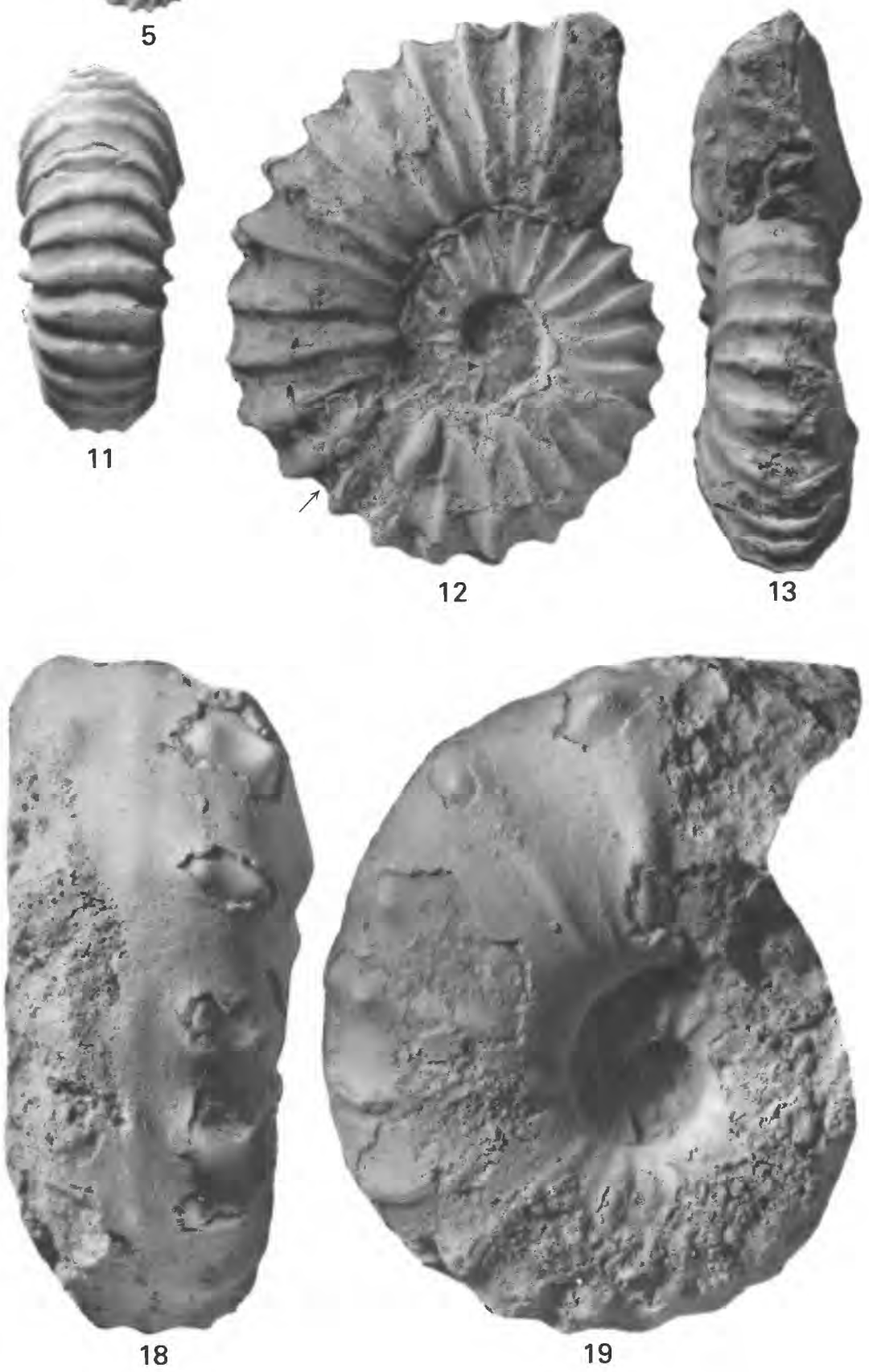

CALYCOCERAS AND ACANTHOCERAS 


\section{PLATE 2}

[All figures natural size except as indicated. Arrow marks base of body chamber]

Figures 1-29. Acanthoceras bellense Adkins (p. 5).

1-3. Front, side, and rear views of hypotype USNM 388094, from USGS Mesozoic locality D5869 (text fig. 1).

4, 5. Front and side views of hypotype USNM 388095, from the same locality.

6-8. Front, side, and rear views of hypotype USNM 388096, from the same locality.

9-11. Rear, side, and front views, $\times 2$, of hypotype USNM 388097 , from USGS Mesozoic locality D8841 (text fig. 1).

12-14. Front, side, and rear views of hypotype USNM 388098, from the same locality as figures 9-11.

15, 16. Rear and side views of hypotype USNM 388099, from the same locality.

17. View of a cross section of a fragment of a large phragmocone. Hypotype USNM 388100, from the same locality as figures 1-3.

18. Side view of variant that has a nearly smooth outer whorl. Hypotype USNM 388101, from the same locality as figures 9-11.

19-21. Rear, side, and front views of hypotype USNM 388102, from the same locality.

22,23 . Side and front views of hypotype USNM 388103 , from the same locality.

24,25 . Side and front views, $\times 2$, of hypotype USNM 388104 , from the same locality.

26,27 . Rear and side views of hypotype USNM 388105 , from the same locality.

28 , 29. Rear and side views of part of an adult body chamber. Hypotype USNM 388106, from the same locality. 


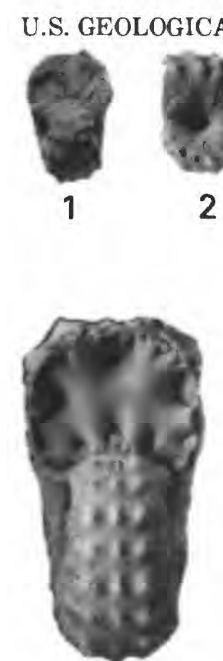

12

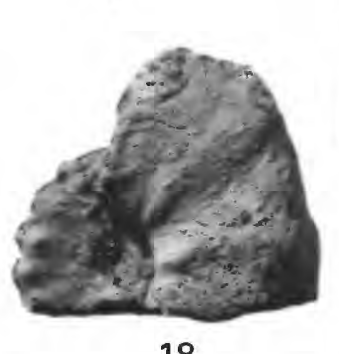

18
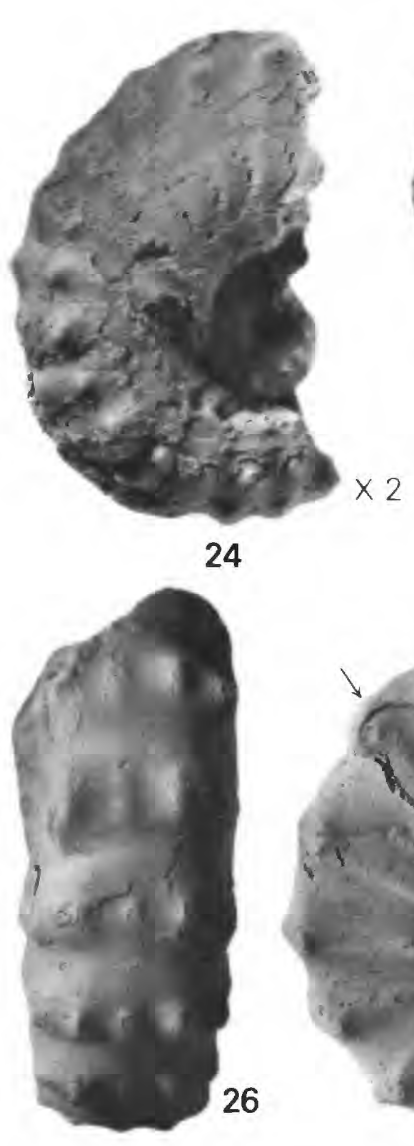

13
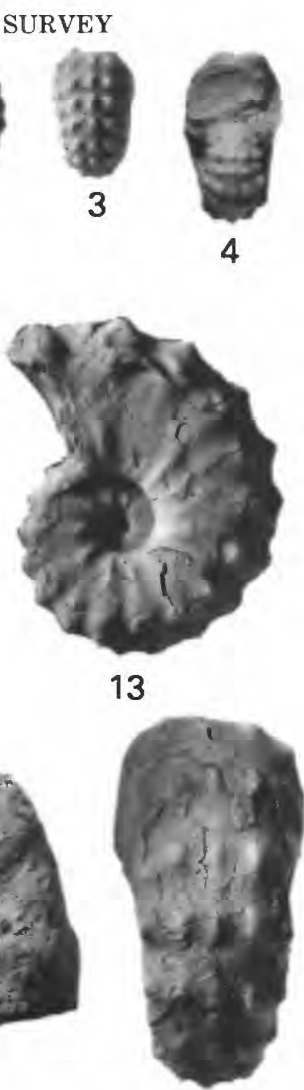

19
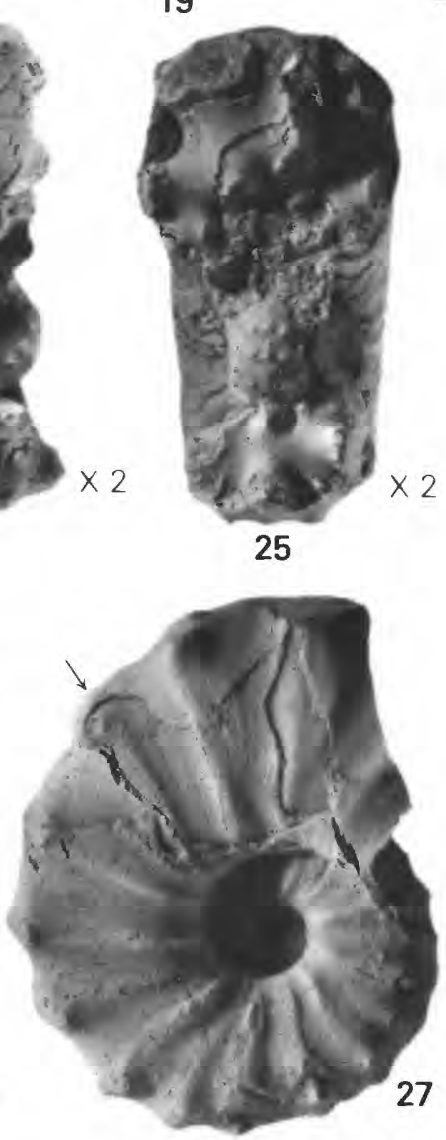
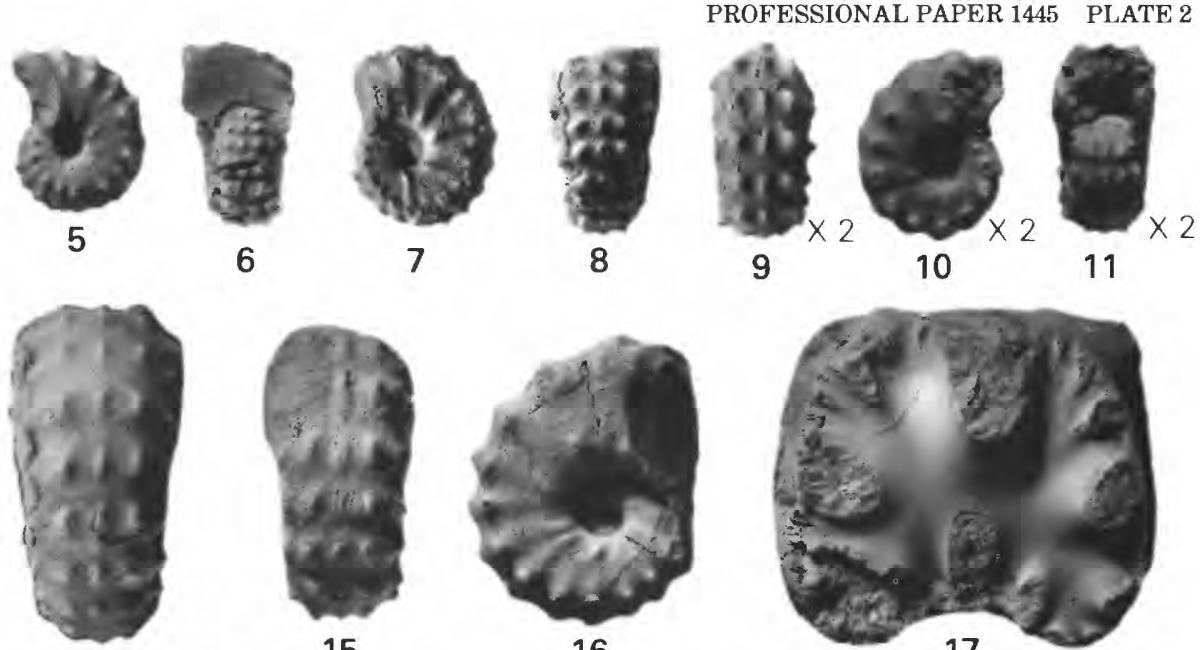

15
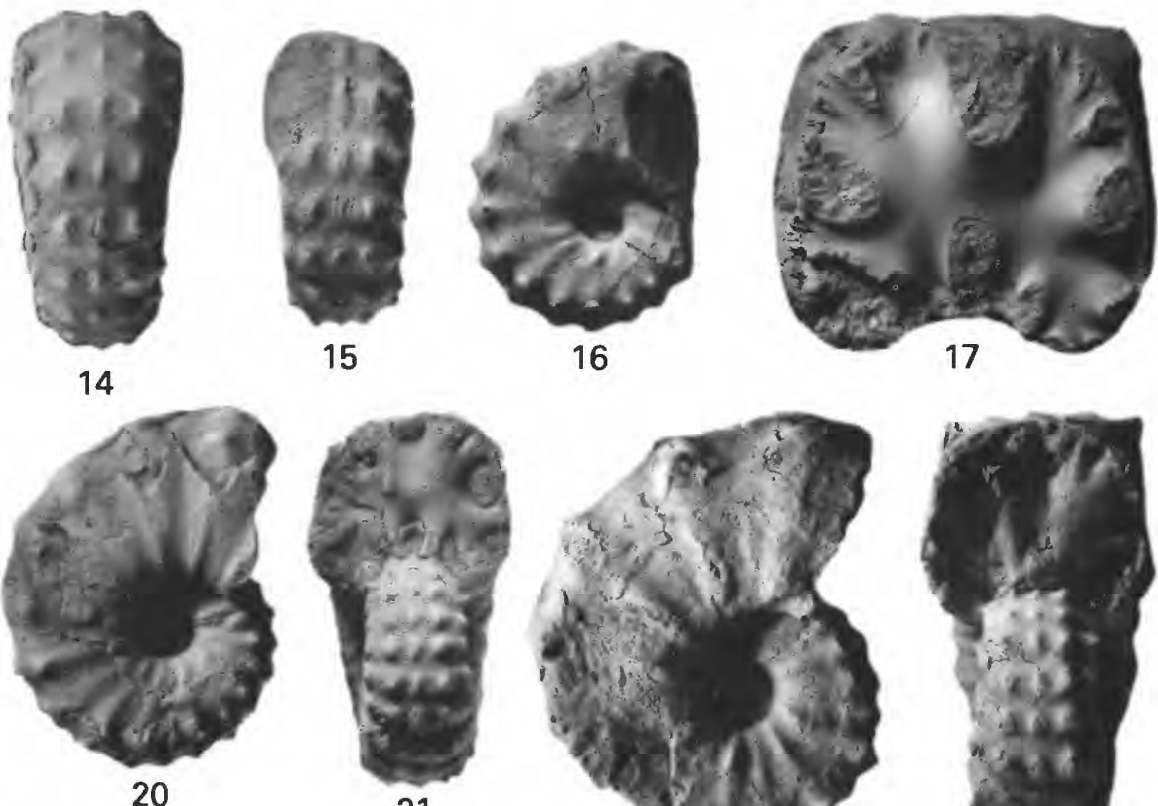

21
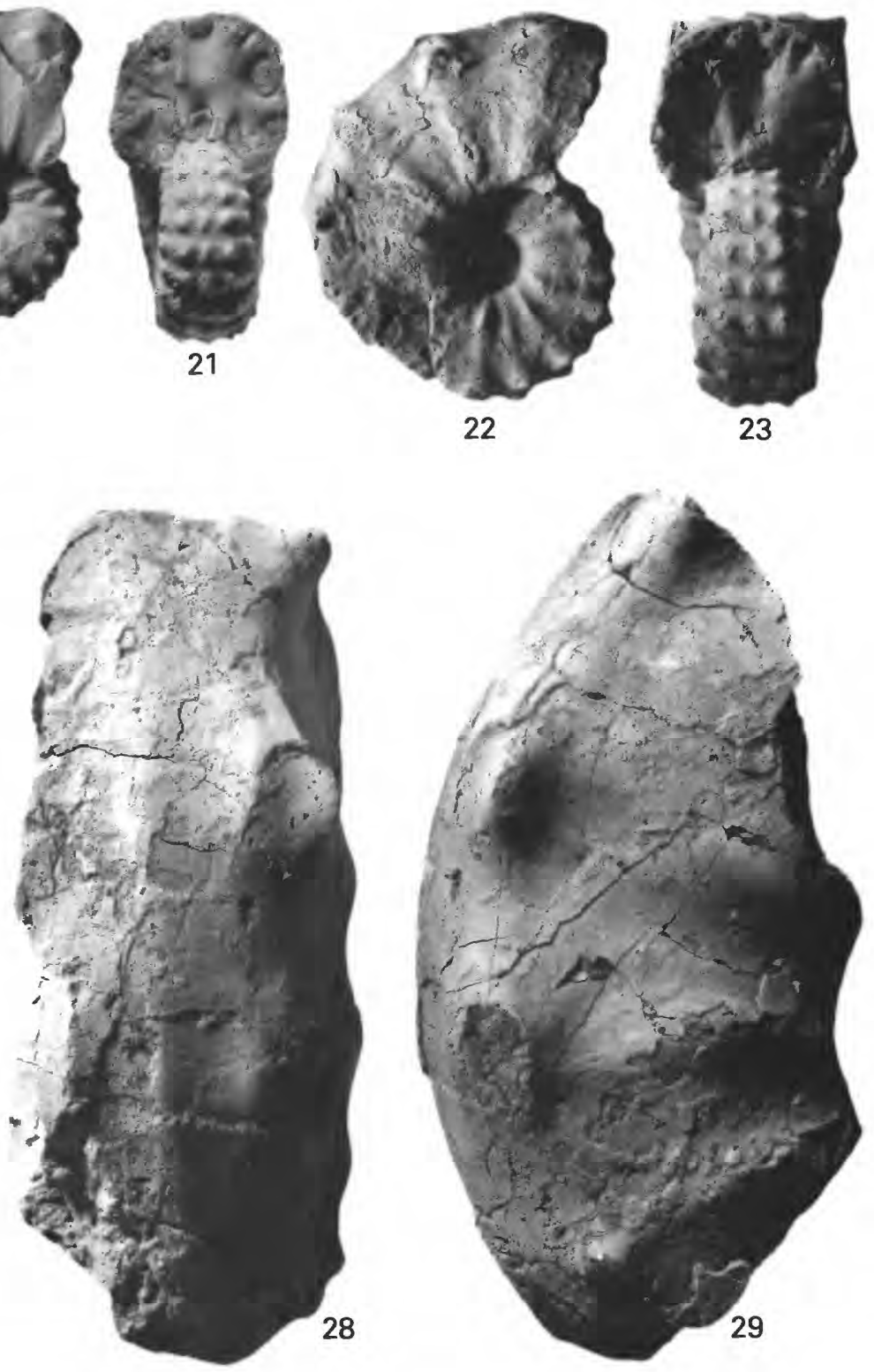

ACANTHOCERAS 


\section{PLATE 3}

[All figures natural size except as indicated. Arrows mark base of body chambers]

1-3. Front, side, and rear views of paratype USNM 388111, from USGS Mesozoic locality 23459 (text fig. 1).

4-6. Rear, side, and front views of holotype USNM 388110, from the same locality.

7-34. Acanthoceras muldoonense Cobban and Scott (p. 7).

7-9. Rear, side, and front views of hypotype USNM 388112, from the same locality as figures 1-3.

10-12. Rear, side, and front views of hypotype USNM 388113, from USGS Mesozoic locality D9801 (text fig. 1).

13-15. Front, side, and rear views of hypotype USNM 388114, from the same locality as figures $1-3$.

16-18. Rear, side, and front views, $\times 2$, of hypotype USNM 388115 , from the same locality.

19-21. Rear, side, and front views of hypotype USNM 388116, from the same locality.

22-24. Front, side, and rear views of hypotype USNM 388117 , from the same locality.

25, 26. Front and side views of hypotype USNM 388118, from the same locality.

27,28 . Rear and side views of hypotype USNM 388119 , from the same locality as figures 10-12.

29,30 . Rear and side views of a fragment of a body chamber that has looped ribs across the venter. Hypotype USNM 388120 , from the same locality.

31, 32. Rear and side views of hypotype USNM 388121, from the same locality.

33,34 . Rear and side views of hypotype USNM 388122 , from the same locality. 
U.S. GEOLOGICAL SURVEY

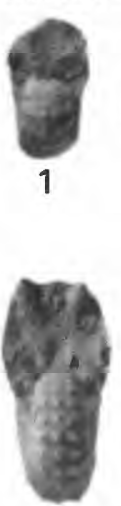

13

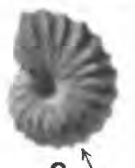

21

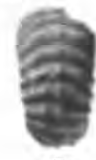

3

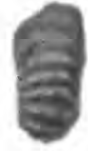

4
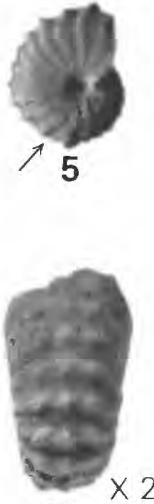

16

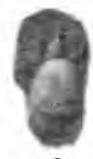

6

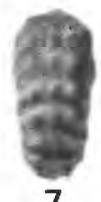

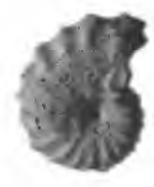

8
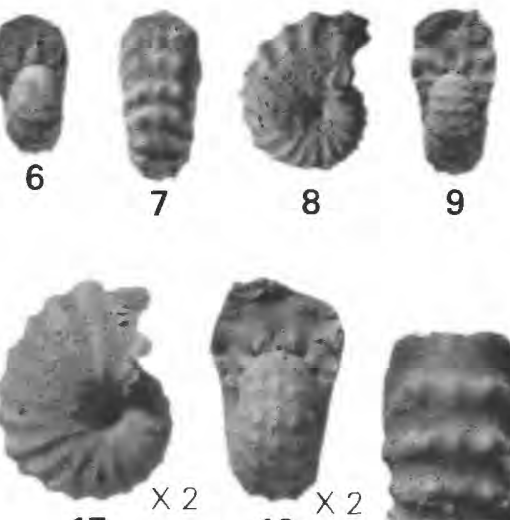

17
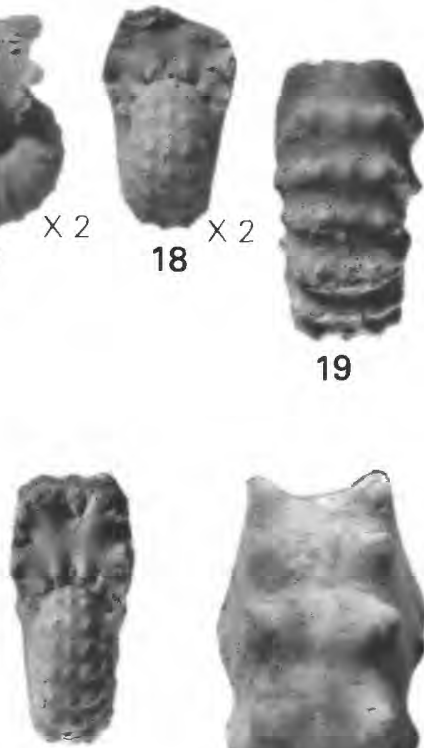

25
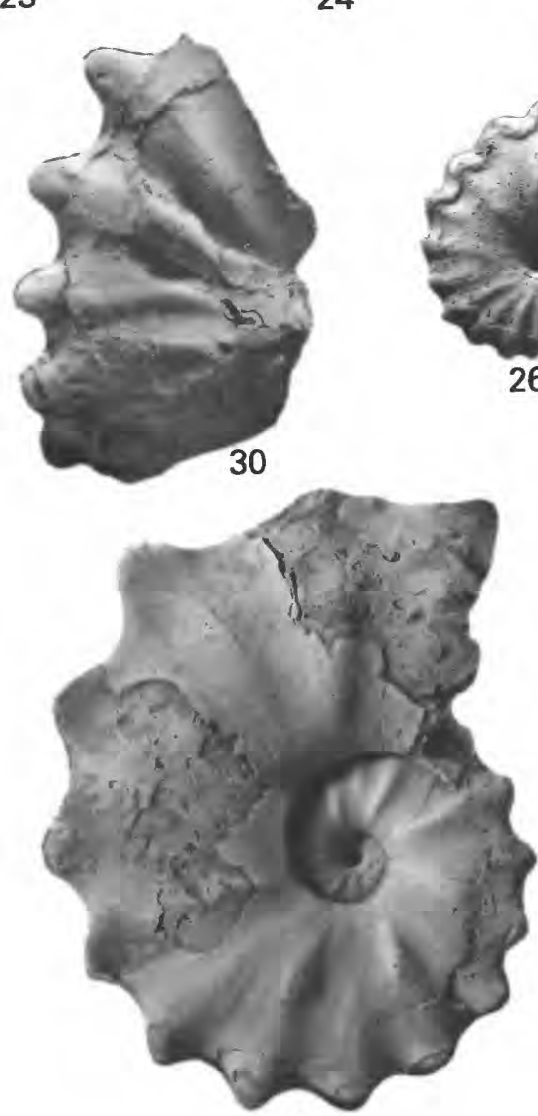

32
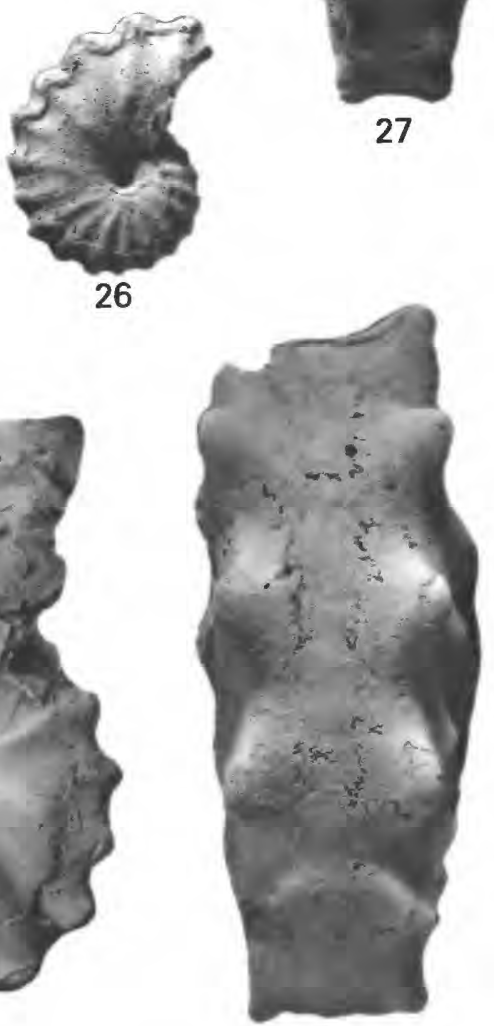

33

27
19

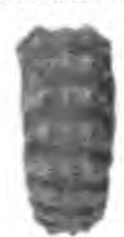

10

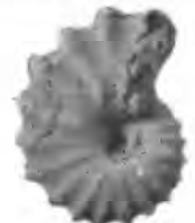

11

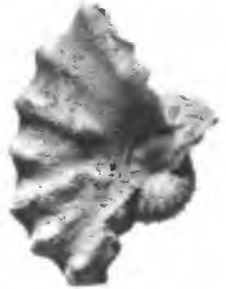

20
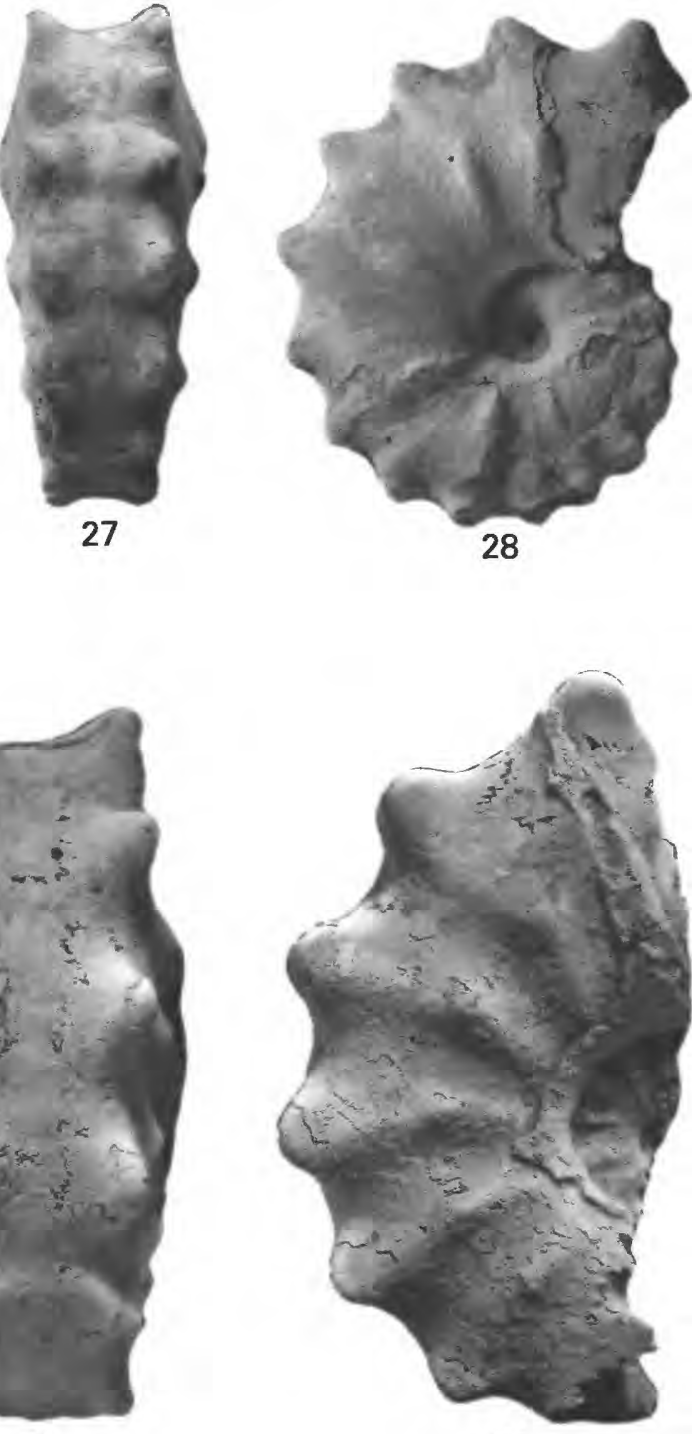

34 


\section{PLATE 4}

[All figures natural size. Arrows mark base of body chambers]

Figures 1-11. Cunningtoniceras amphibolum amphibolum (Morrow) (p. 11).

1-3. Rear, side, and front views of a small syntype from the Graneros Shale near Wilson, Kans.

4-6. Front, side, and rear views of the lectotype from the same locality.

7-9. Side, front, and rear views of hypotype USNM 388123, from USGS Mesozoic locality 12510 (text fig. 1).

10. Side view of part of the body chamber of an adult macroconch. Hypotype USNM 388124, from USGS Mesozoic locality D4428 (text fig. 1).

11. Side view of a partially crushed microconch. Hypotype USNM 388125 , from the same locality. 


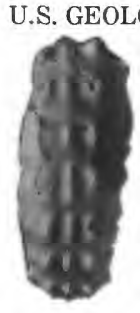

1

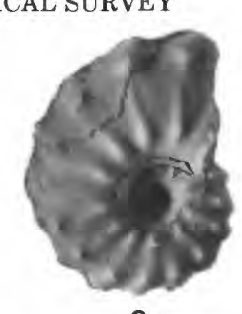

2

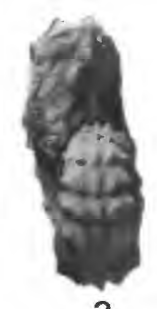

3
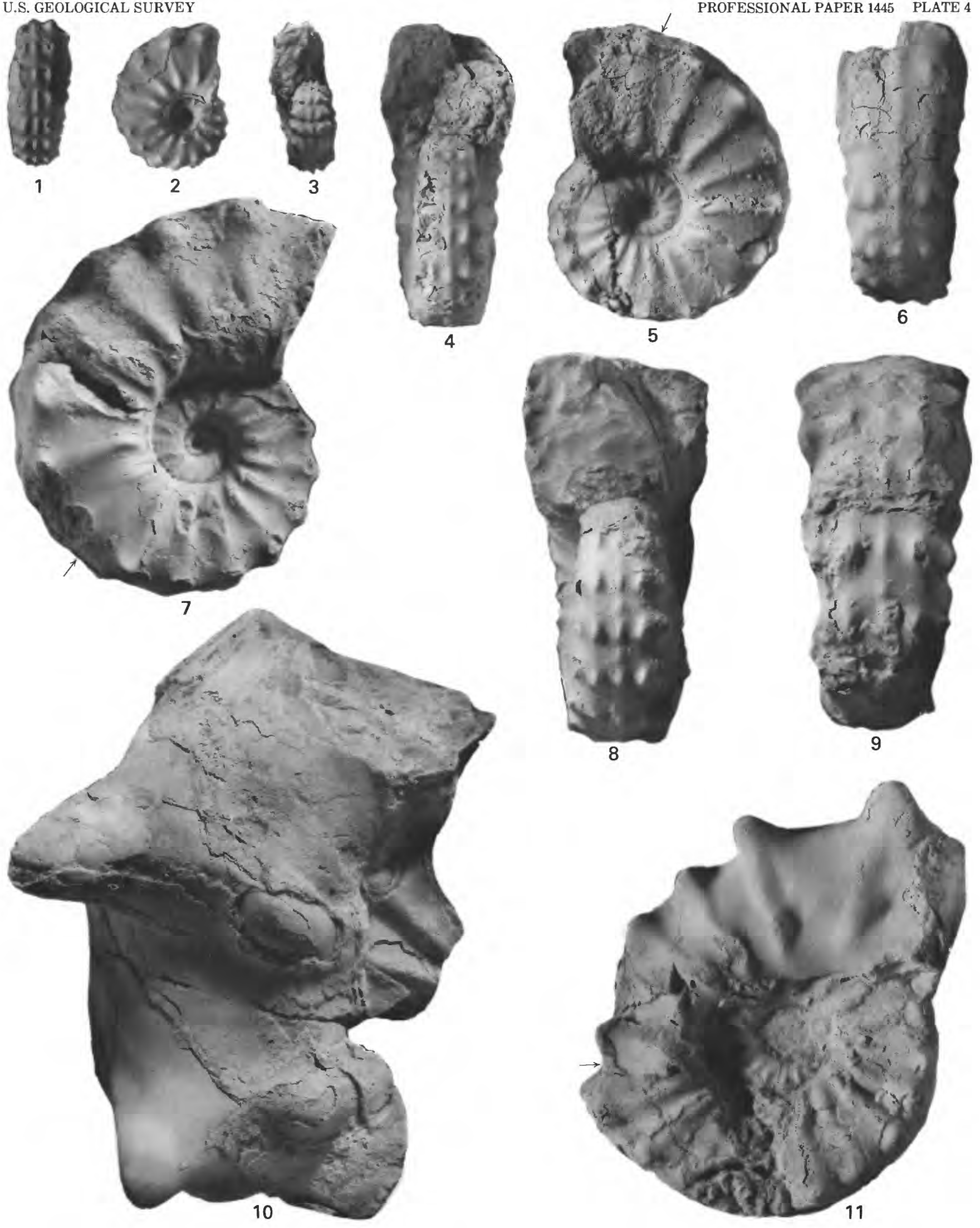

CUNNINGTONICERAS 


\section{PLATE 5}

[All figures natural size. Arrows mark base of body chambers]

Figures 1-25. Cunningtoniceras amphibolum amphibolum (Morrow) (p. 11).

From the Belle Fourche Shale at USGS Mesozoic locality D5900 (text fig. 1).

1-3. Front, side, and rear views of hypotype USNM 388126.

4-6. Front, side, and rear views of hypotype USNM 388127.

7-9. Rear, side, and front views of hypotype USNM 388128.

10, 11. Side and rear views of hypotype USNM 388129.

12, 13. Side and front views of hypotype USNM 388130 .

14-16. Front, side, and rear views of hypotype USNM 388131.

17, 18. Side and rear views of hypotype USNM 388132.

19. Side view of hypotype USNM 388133.

20-22. Front, side, and rear views of hypotype USNM 388134.

23-25. Front, side, and rear views of hypotype USNM 388135.

26, 27. Cunningtoniceras amphibolum fallense Cobban, n. subsp. (p. 13).

Top and side views of the holotype USNM 388136, from USGS Mesozoic locality D7370 (text fig. 1). 


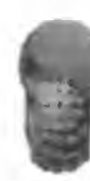

1
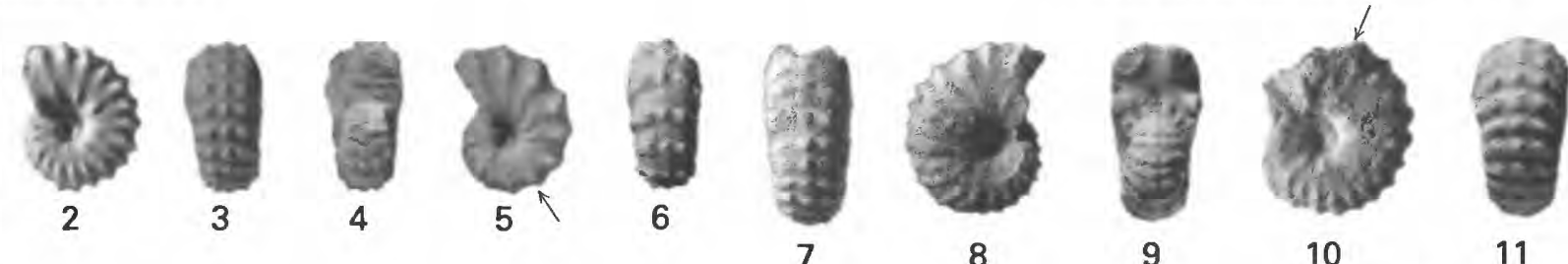

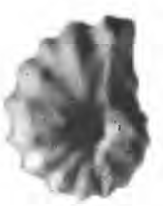

12

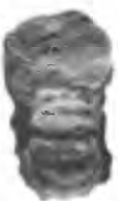

13

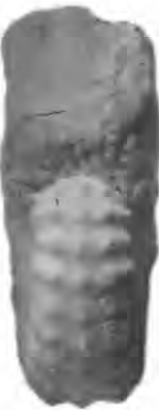

20

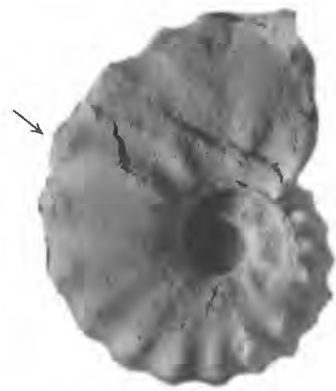

21

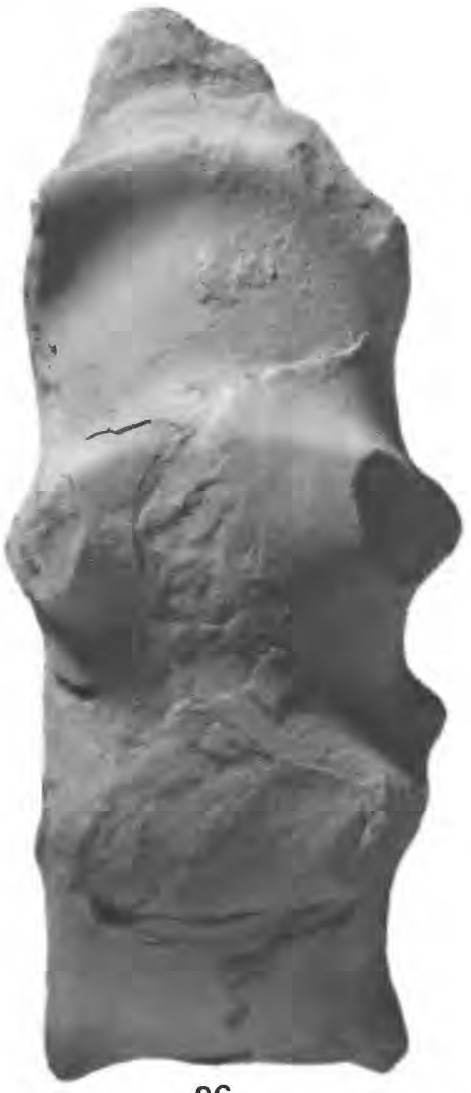

26
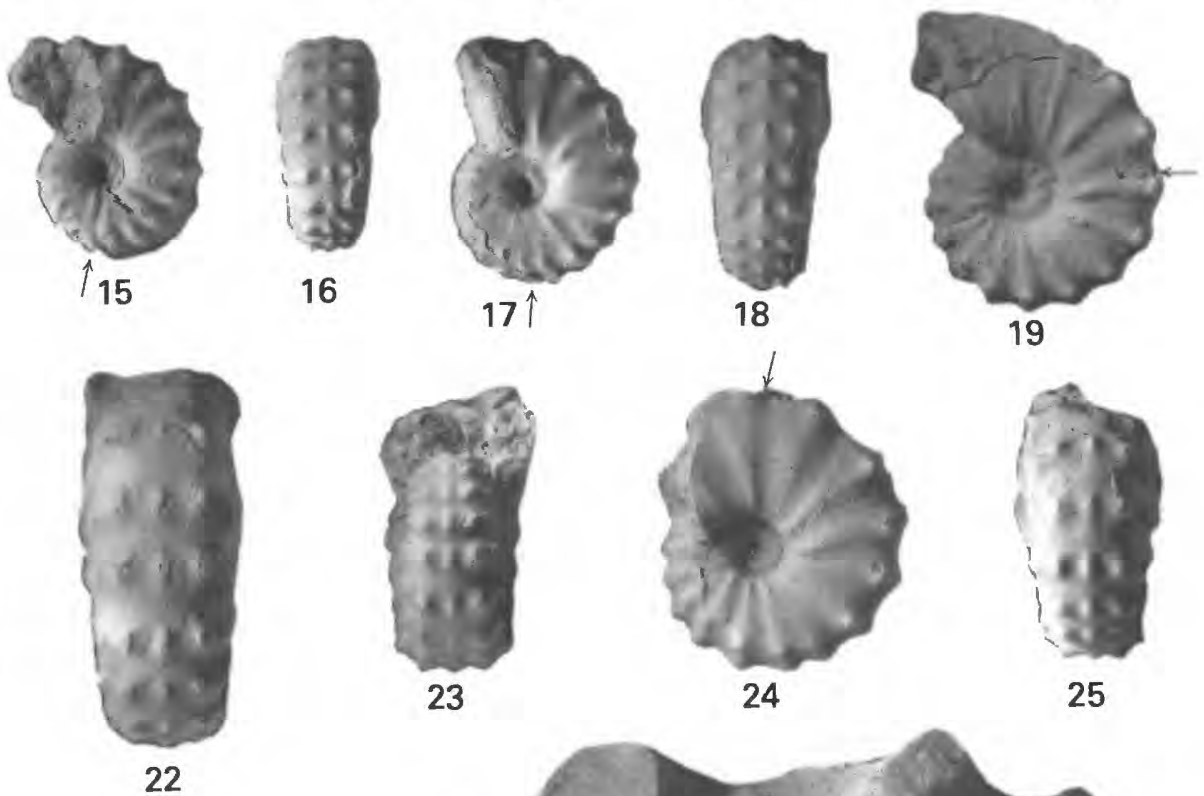

25

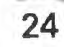

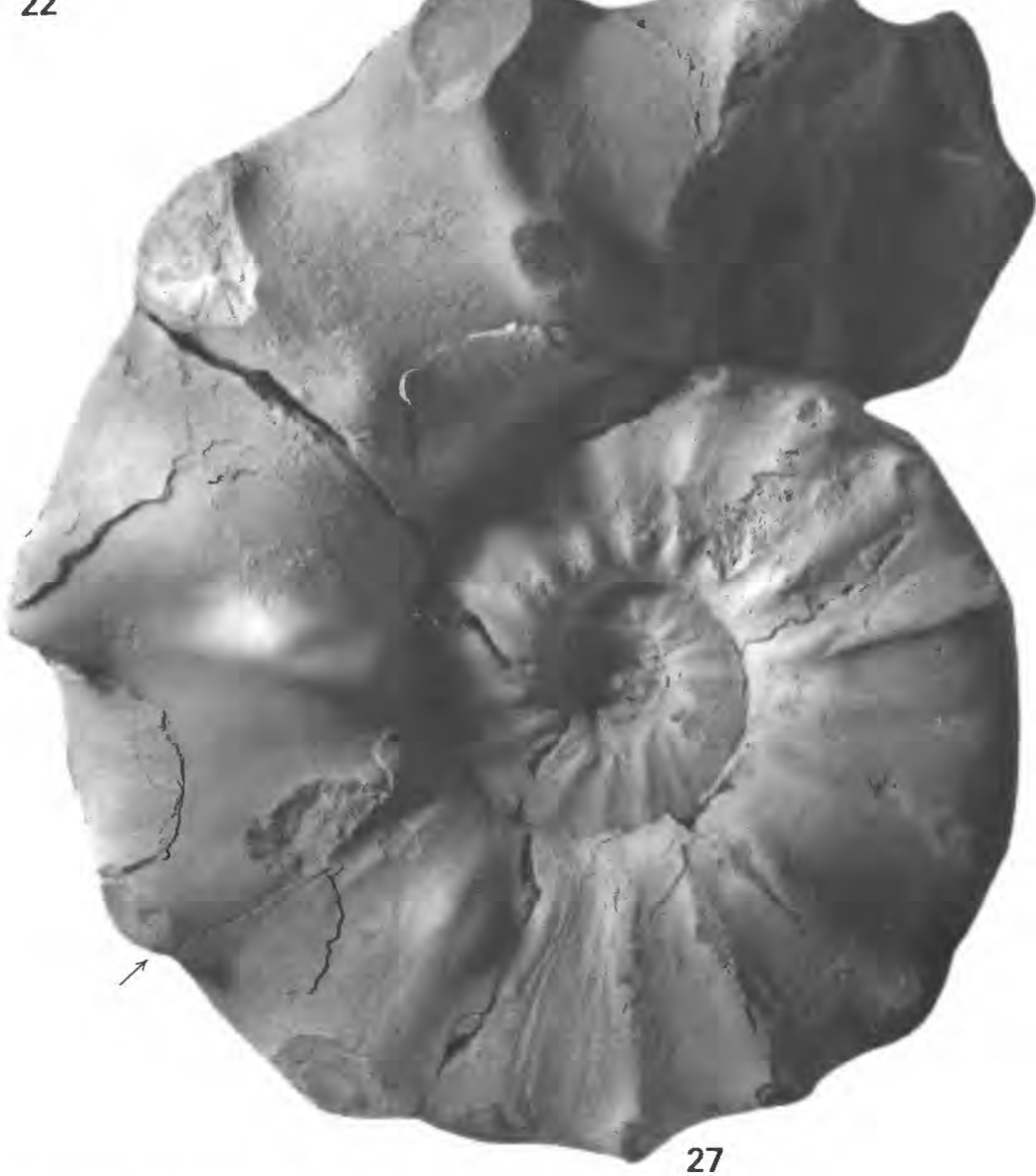

CUNNINGTONICERAS 


\section{PLATE 6}

[All figures natural size. Arrow points to base of body chamber]

Figures 1-9. Cunningtoniceras amphibolum fallense Cobban, n. subsp. (p. 13).

From the Belle Fourche Shale at USGS Mesozoic locality D7370 (text fig. 1).

1, 2. Rear and side views of a specimen that has riblets on the ribs and in the interspaces. Paratype USNM 388137.

3, 4. Side and front views of another specimen that has riblets. Paratype USNM 388138.

5, 6. Rear and side views of paratype USNM 388139.

7. Side view of a specimen that shows loss of ribbing on part of the outer whorl. Paratype USNM 388140.

8, 9. Rear and side views of paratype USNM 388141 . 
U.S. GEOLOGICAL SURVEY
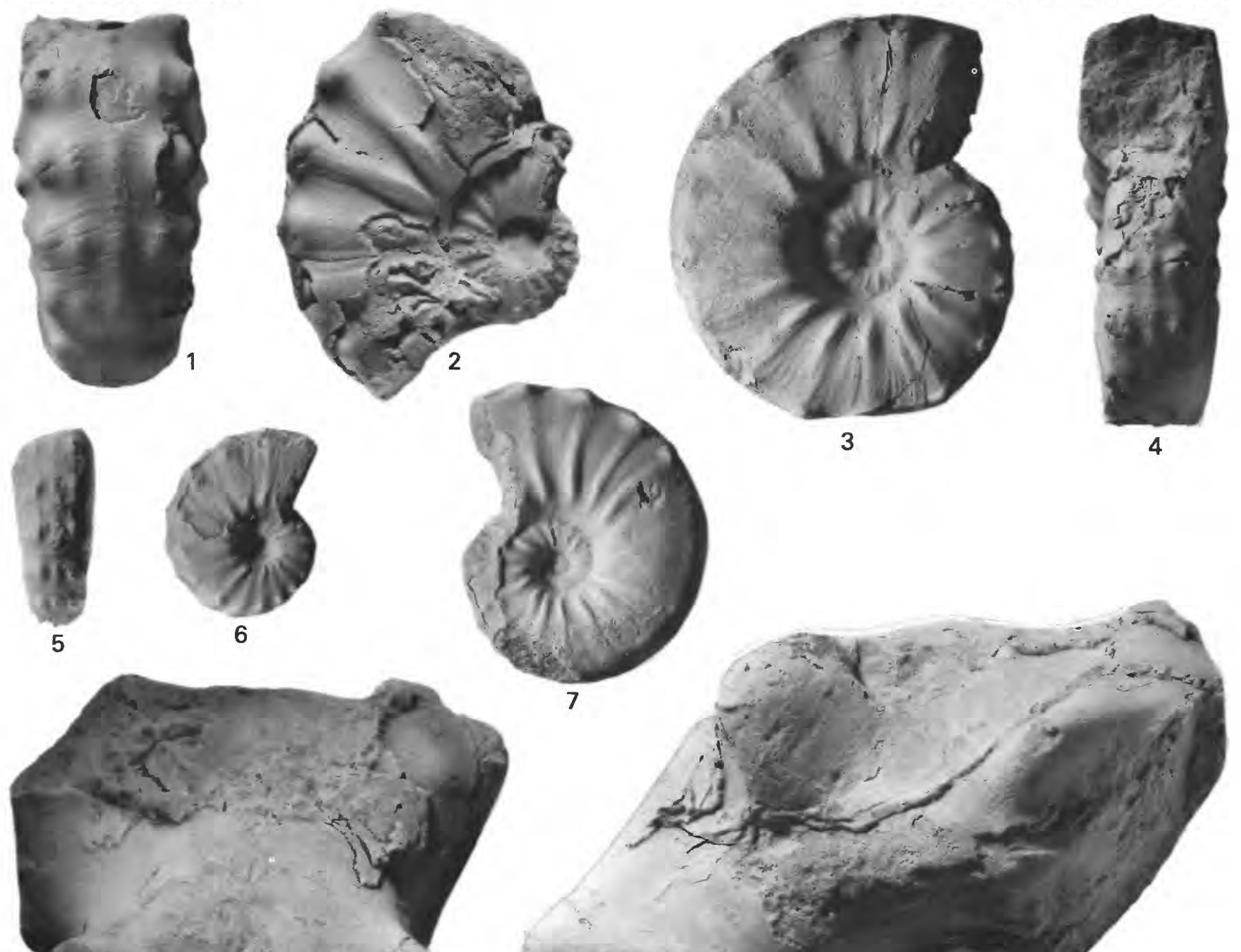


\section{PLATE 7}

[All figures natural size. Arrows mark base of body chambers]

1-9. Cunningtoniceras amphibolum fallense Cobban, n. subsp. (p. 13).

From the Frontier Formation at USGS Mesozoic locality 22804 (text fig. 1). 1-3. Rear, side, and front views of paratype USNM 388142.

4, 5. Rear and side views of a specimen that shows loss of ornament on the younger end of the adult body chamber. Paratype USNM 388143.

6. Side view of paratype USNM 388144 .

7. Side view of paratype USNM 388145 .

8, 9. Rear and side views of paratype USNM 388146 . 

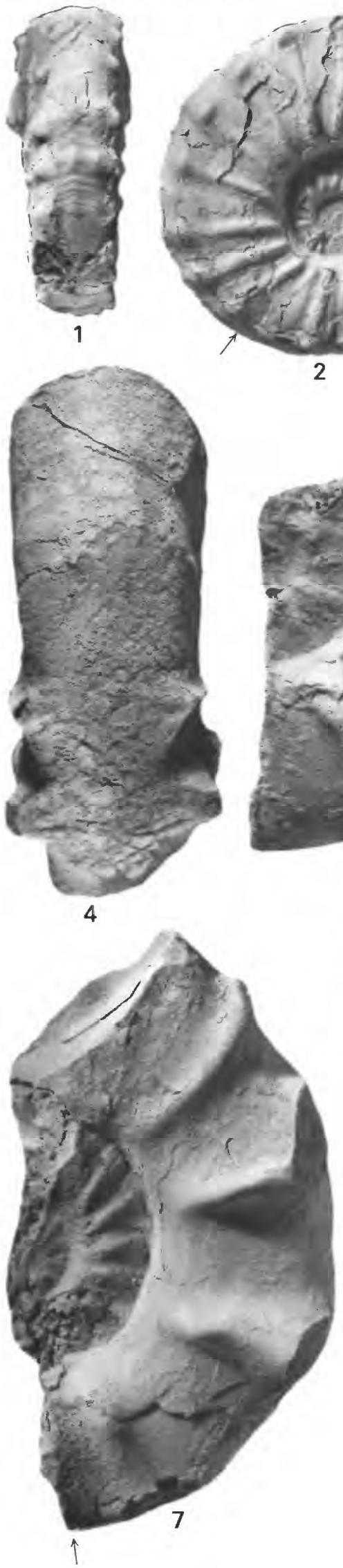
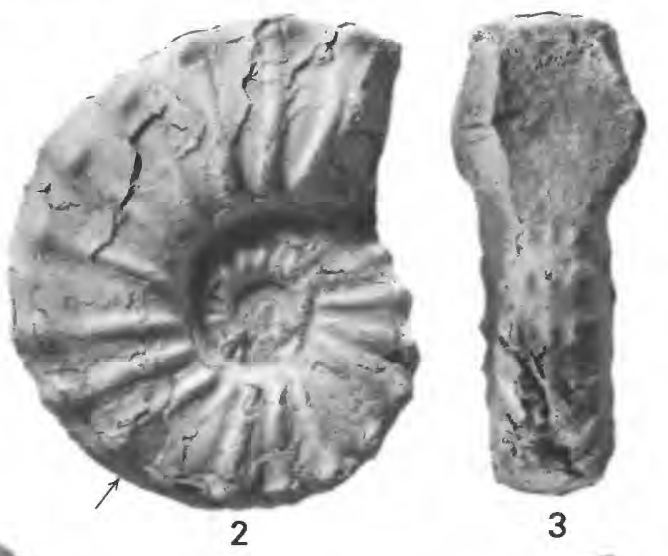

3
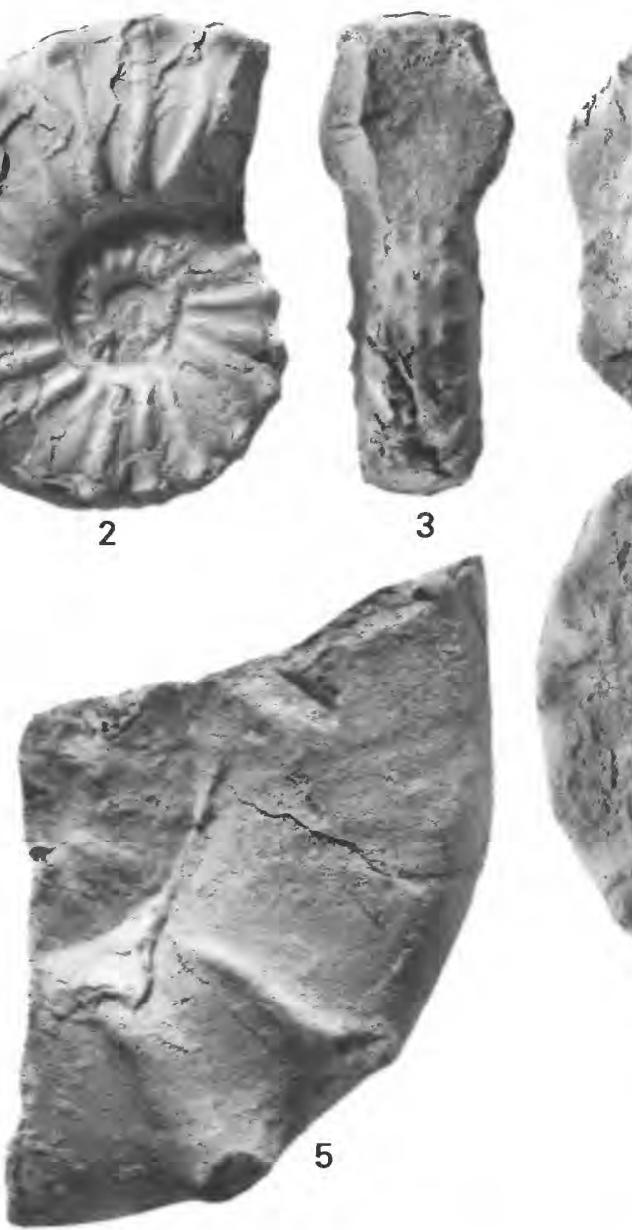

i)

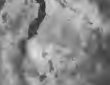

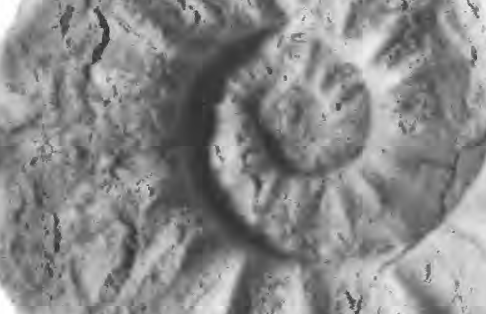

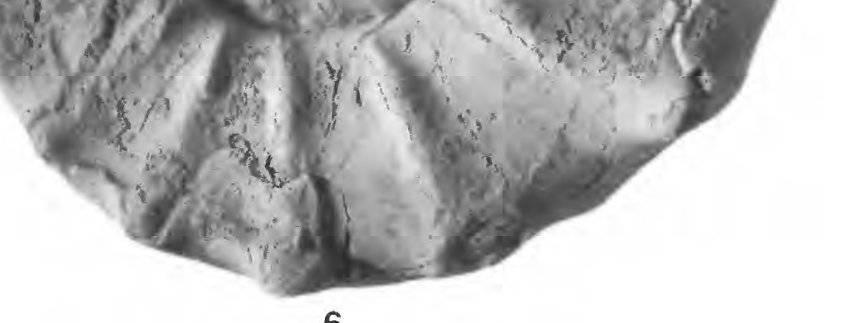

6
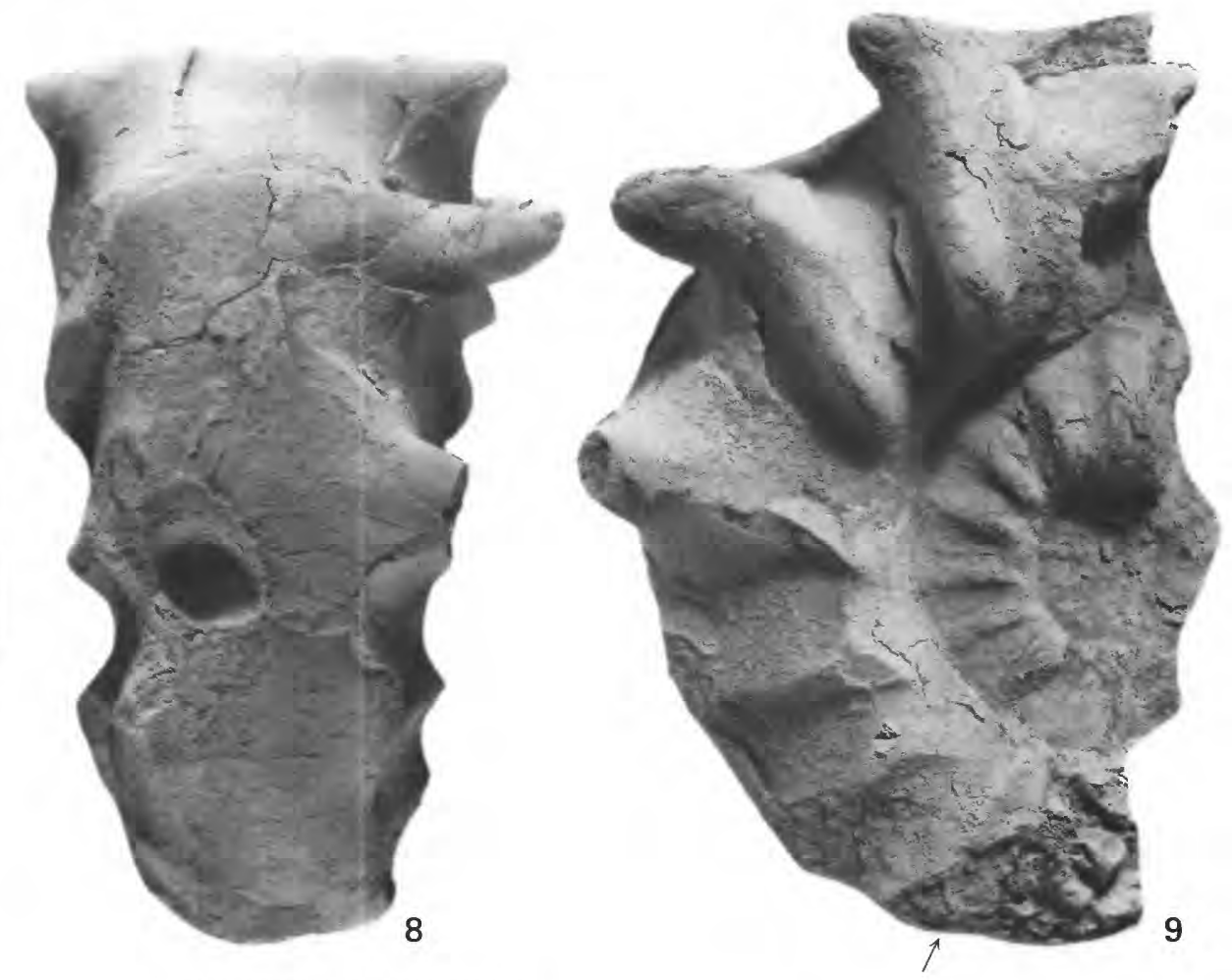

CUNNINGTONICERAS 


\section{PLATE 8}

[Both views natural size. Arrow marks base of body chamber]

Cunningtoniceras amphibolum fallense Cobban, n. subsp. (p. 13).

Front and side views of paratype USNM 388147, from the Belle Fourche Shale at USGS Mesozoic locality D8442 (text fig. 1). 


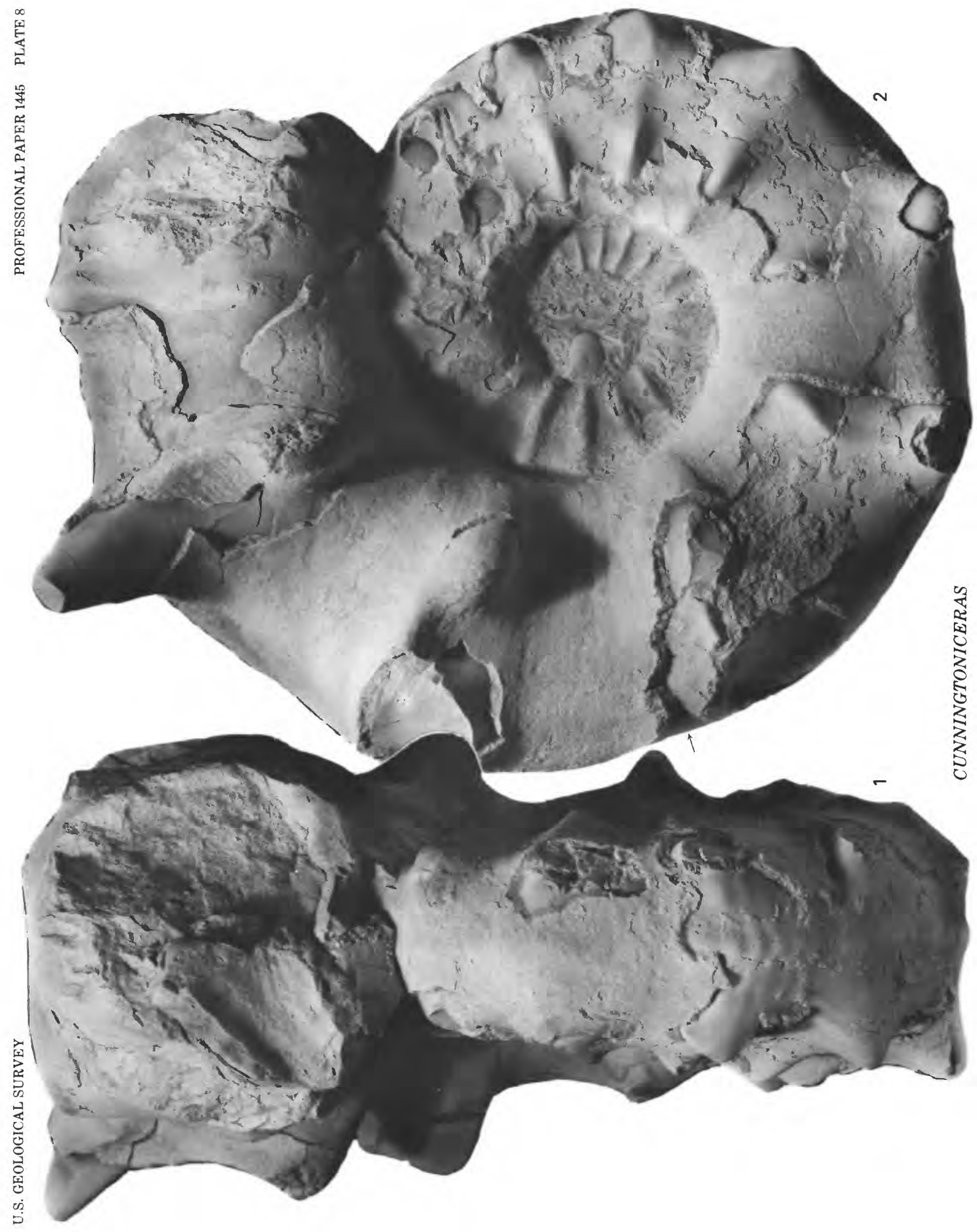




\section{PLATE 9}

[All figures natural size except as indicated. Arrows mark base of body chambers]

Figures 1-27. Protacanthoceras hosei hosei Cobban, n. subsp. (p. 18).

1-3. Front, side, and rear views of paratype USNM 388171, from the Frontier Formation at USGS Mesozoic locality 22804 (text fig. 1).

4 , 5. Rear and side views of paratype USNM 388172, from the same locality.

6-9. Front, side, rear, and top views of paratype USNM 388173, from the same locality.

10-12. Top, rear, and side views of paratype USNM 388174, from the same locality.

13-15. Front, side, and rear views of the holotype USNM 388170 , from the same locality.

16-18. Side, rear, and top views of paratype USNM 388175, from the same locality.

19, 20. Side and rear views of paratype USNM 388176, from the same locality.

21, 22. Top and side views of paratype USNM 388177, from the Belle Fourche Shale at USGS Mesozoic locality D7370 (text fig. 1).

23,24 . Side and rear views of paratype USNM 388178 , from the same locality.

25-27. Front, side, and rear views of paratype USNM 377179, from the same locality.

28-47. Protacanthoceras hosei sheridanense Cobban, n. subsp. (p. 20).

From the Frontier Formation at USGS Mesozoic locality D6933 (text fig. 1).

28-30. Front, side, and rear views of paratype USNM 388182.

31-33. Front, side, and rear views of the holotype USNM 388181.

34-36. Rear, side, and front views, $\times 2$, of paratype USNM 388183.

37-39. Rear, side, and front views, $\times 2$, of paratype USNM 388184.

40-42. Rear, side, and front views, $\times 2$, of paratype USNM 388185 .

43-45. Front, side, and rear views, $\times 2$, of paratype USNM 388186 .

46, 47. Rear and side views of paratype USNM 388187.

48-63. Cunningtoniceras amphibolum fallense Cobban, n. subsp. (p. 13).

48-56. Views of the outer whorls, intermediate whorls, and inner whorls of paratype USNM 388148, from the Frontier Formation at USGS Mesozoic locality 20934 (text fig. 1).

57, 58. Front and side views of paratype USNM 388149 , from the Frontier Formation at USGS Mesozoic locality 21364 (text fig. 1).

59-61. Rear, side, and front views of paratype USNM 388150 , from the Belle Fourche Shale at USGS Mesozoic locality D8442 (text fig. 1).

62,63 . Side and front views of paratype USNM 388151 , from the same locality as figures $48-56$. 
te

1

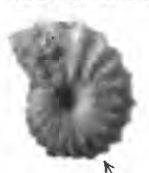

2

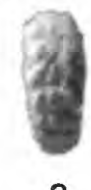

3

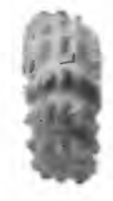

4
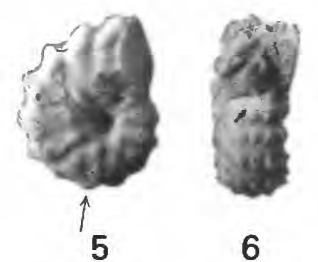

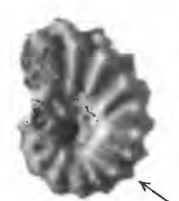

7

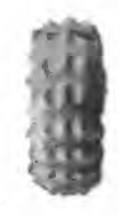

8

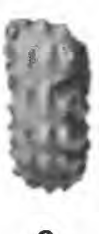

9

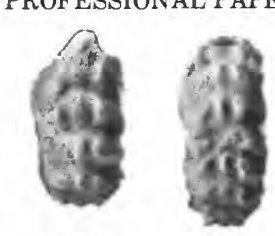

$10 \quad 11$

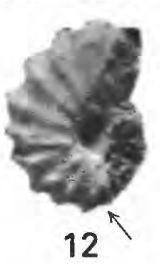

12

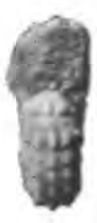

13

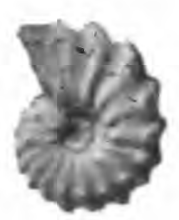

14

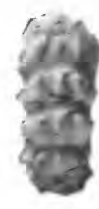

15

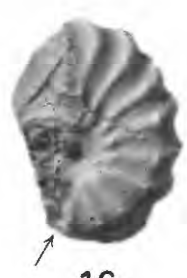

16

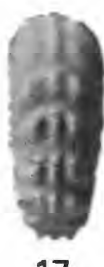

17

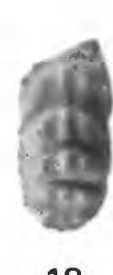

18

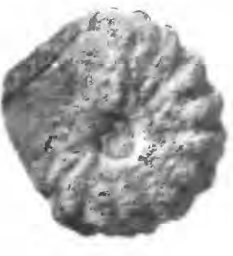

19

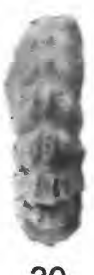

20

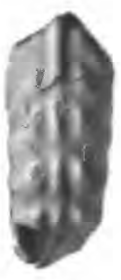

21

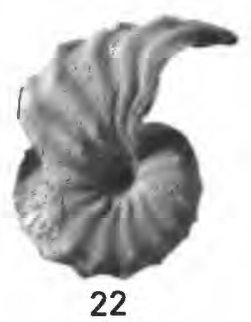

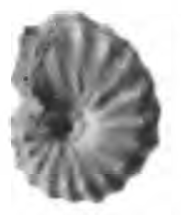

23

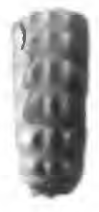

24

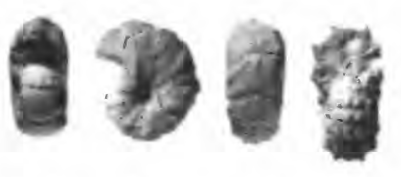

$25 \quad 26$

$27 \quad 28$

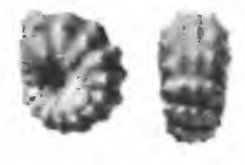

$29 \quad 30$

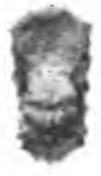

31

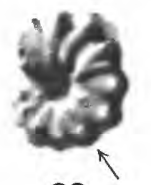

32

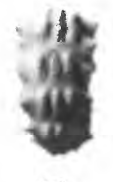

33

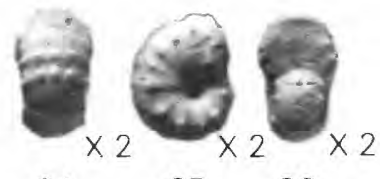

$34 \quad 35 \quad 36$
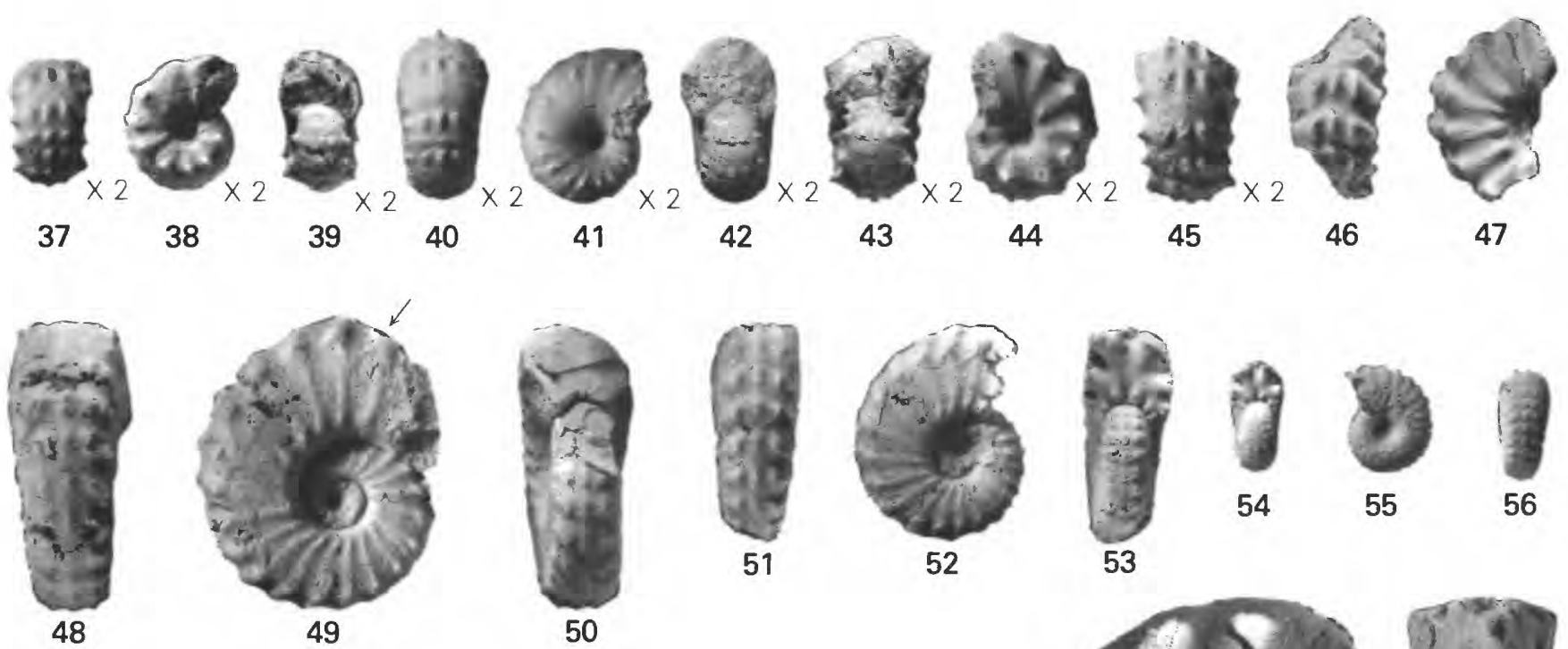

54

55

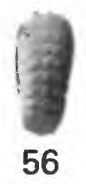

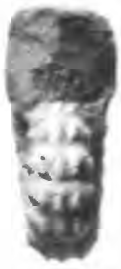

57

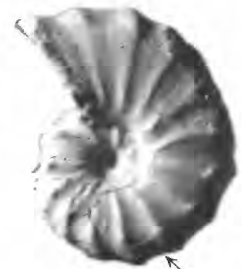

58

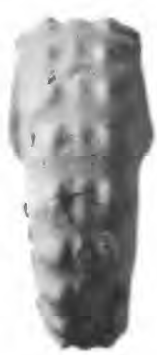

59

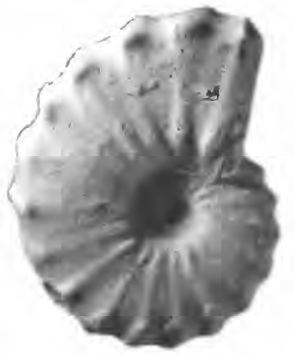

60

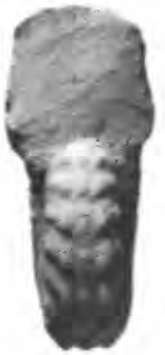

61
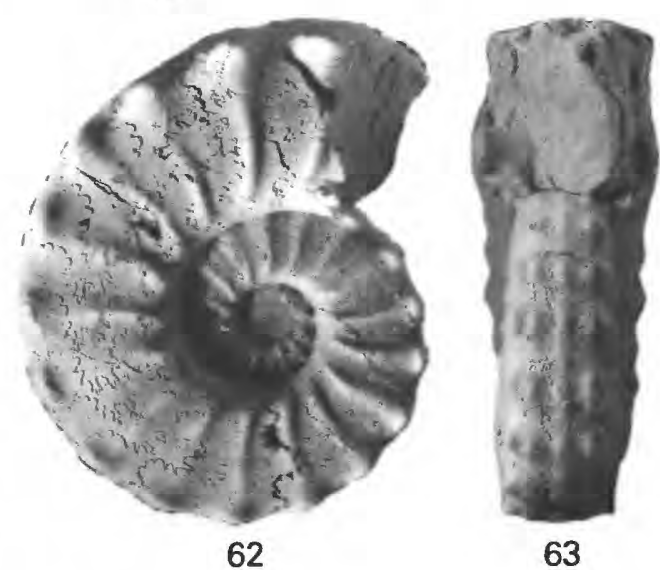

PROTACANTHOCERAS AND CUNNINGTONICERAS 


\section{PLATE 10}

[All figures natural size except as indicated. Arrows mark base of body chambers]

Figures 1-28. Protacanthoceras vetula Cobban, n. sp. (p. 21).

From the Belle Fourche Shale at USGS Mesozoic locality D5900 (text fig. 1).

1-3. Front, side, and rear views of paratype USNM 388190.

4-6. Front, side, and rear views of paratype USNM 388191.

7-10. Front, side, rear, and top views of paratype USNM 388192.

11-13. Front, side, and rear views of paratype USNM 388193.

14-17. Top, rear, side, and front views of the holotype USNM 388189.

18-20. Rear, side, and front views, $\times 2$, of paratype USNM 388194

21-23. Front, side, and rear views, $\times 2$, of paratype USNM 388195 .

24,25 . Rear and side views, $\times 2$, of paratype USNM 388196 .

26-28. Rear, side, and front views, $\times 2$, of paratype USNM 388197.

29-47. Protacanthoceras alzadense Cobban, n. sp. (p. 22).

From the Belle Fourche Shale at USGS Mesozoic locality 22871 (text fig. 1). 29-32. Side and rear views, $\times 1$ and $\times 2$, of the holotype USNM 388198 . 33-35. Front, side, and rear views of paratype USNM 388199.

36-38. Rear, side, and front views of paratype USNM 388200.

39 , 40. Rear and side views of paratype USNM 388201.

41-43. Rear, side, and front views of paratype USNM 388202.

44-47. Front, side, rear, and top views of paratype USNM 388203.

48-82. Plesiacanthoceras wyomingense (Reagan) (p. 16).

From the Belle Fourche Shale at USGS Mesozoic locality 22871 (text fig. 1). 48-50. Rear, side, and front views of hypotype USNM 388152.

51-53. Front, side, and rear views of hypotype USNM 388153.

54-56. Front, side, and rear views of hypotype USNM 388154.

57-59. Front, side, and rear views of hypotype USNM 388155.

60-62. Rear, front, and side views of hypotype USNM 388156.

63-65. Front, side, and rear views of hypotype USNM 388157.

66-68. Front, side, and rear views of hypotype USNM 388158.

69-71. Front, side, and rear views of hypotype USNM 388159.

72,73 . Rear and side views of hypotype USNM 388160 .

74-76. Rear, side, and front views of hypotype USNM 388161.

77-79. Rear, side, and front views of hypotype USNM 388162.

80-82. Rear, side, and front views of hypotype USNM 388163. 
U.S. GEOLOGICAL SURVEY
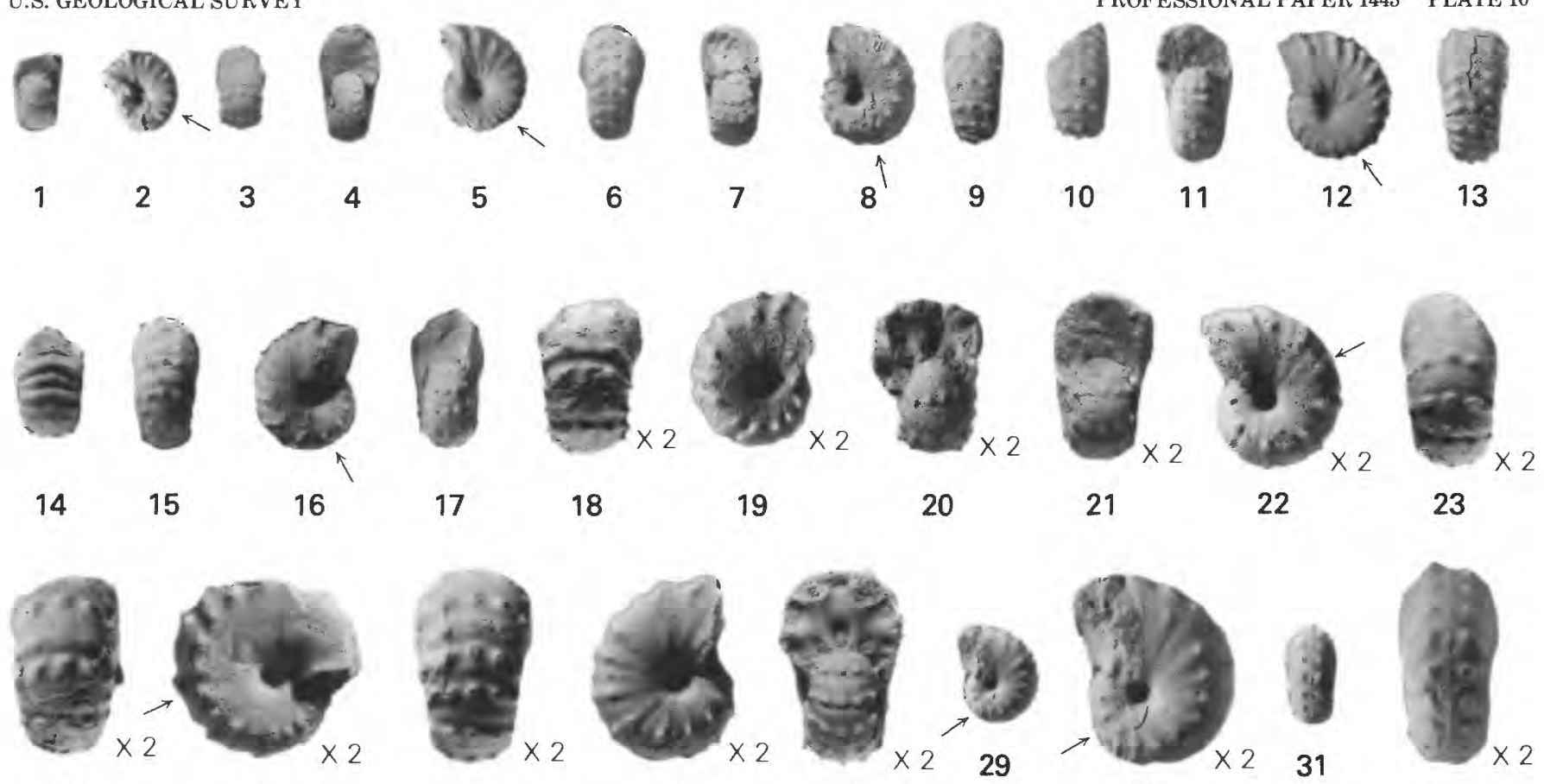

24

25

26

27

28
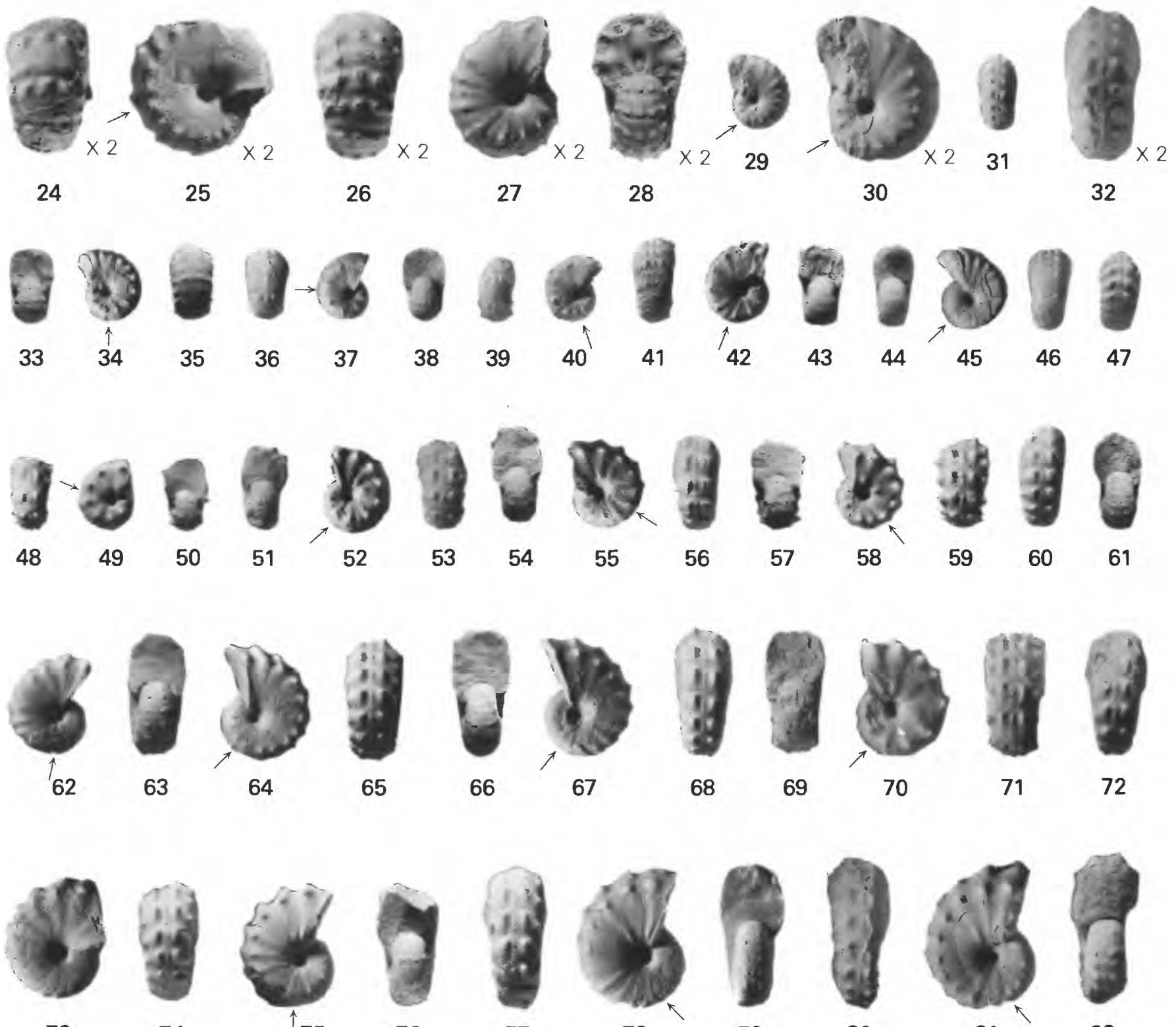

77

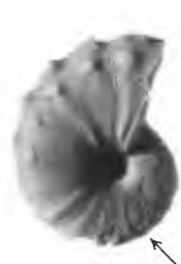

78

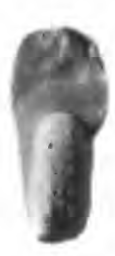

79

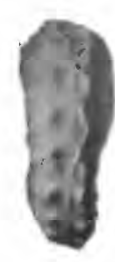

80
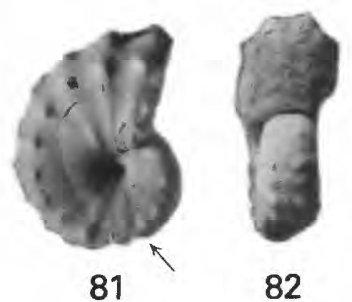

PROTACANTHOCERAS AND PLESIACANTHOCERAS 


\section{PLATE 11}

[All figures natural size. Arrows mark base of body chambers]

Figures 1-13. Plesiacanthoceras wyomingense (Reagan) (p. 16).

From the Belle Fourche Shale at USGS Mesozoic locality 22871 (fig. 1).

1, 2. Rear and side views of hypotype USNM 388164 associated with Hamites sp.

3-7. Views of innermost whorls and intermediate whorls of hypotype USNM 388165. See plate 12 for views of larger whorls.

8 , 9. Side and rear views of hypotype USNM 388166 .

10-13. Views of inner and outer whorls of hypotype USNM 388167. 


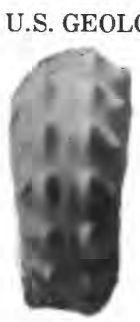

1
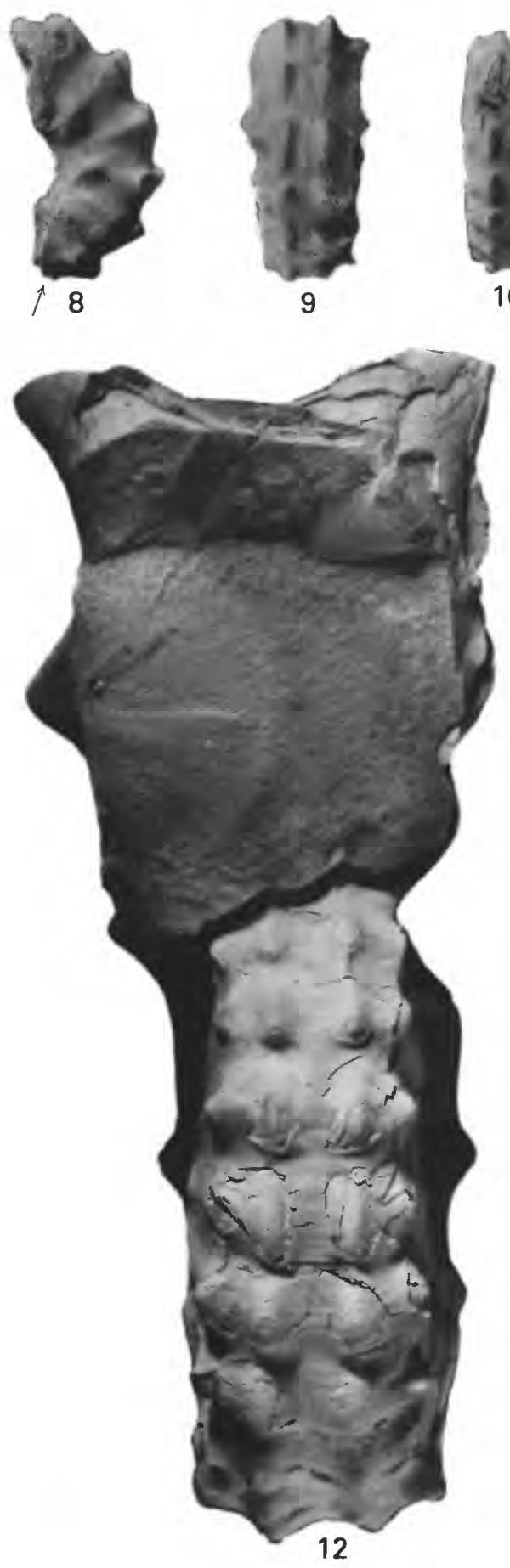

PROFESSIONAL PAPER 1445 PLATE 11
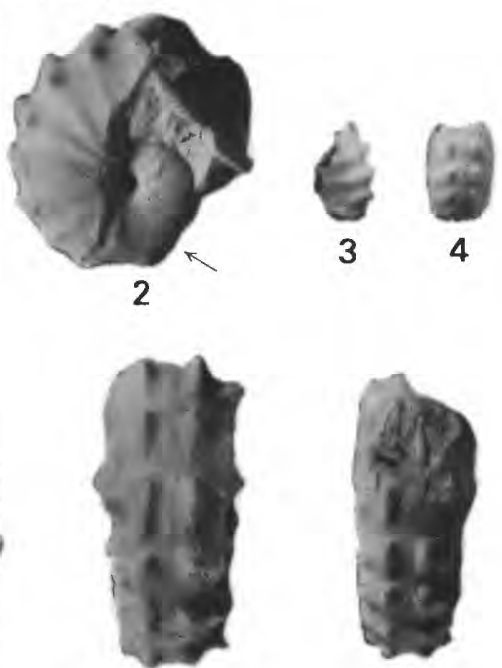

10
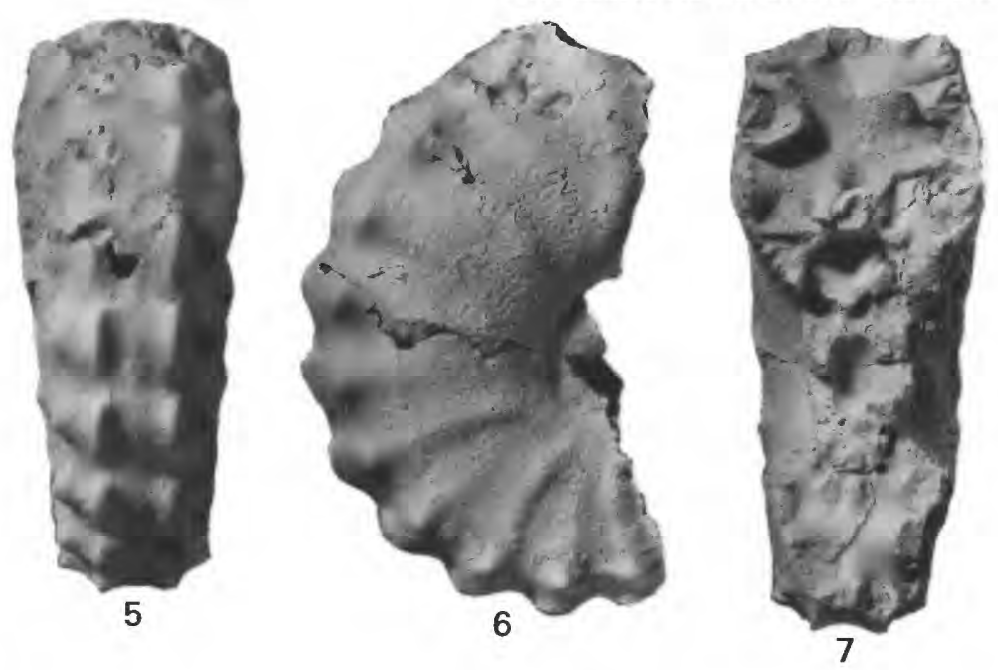

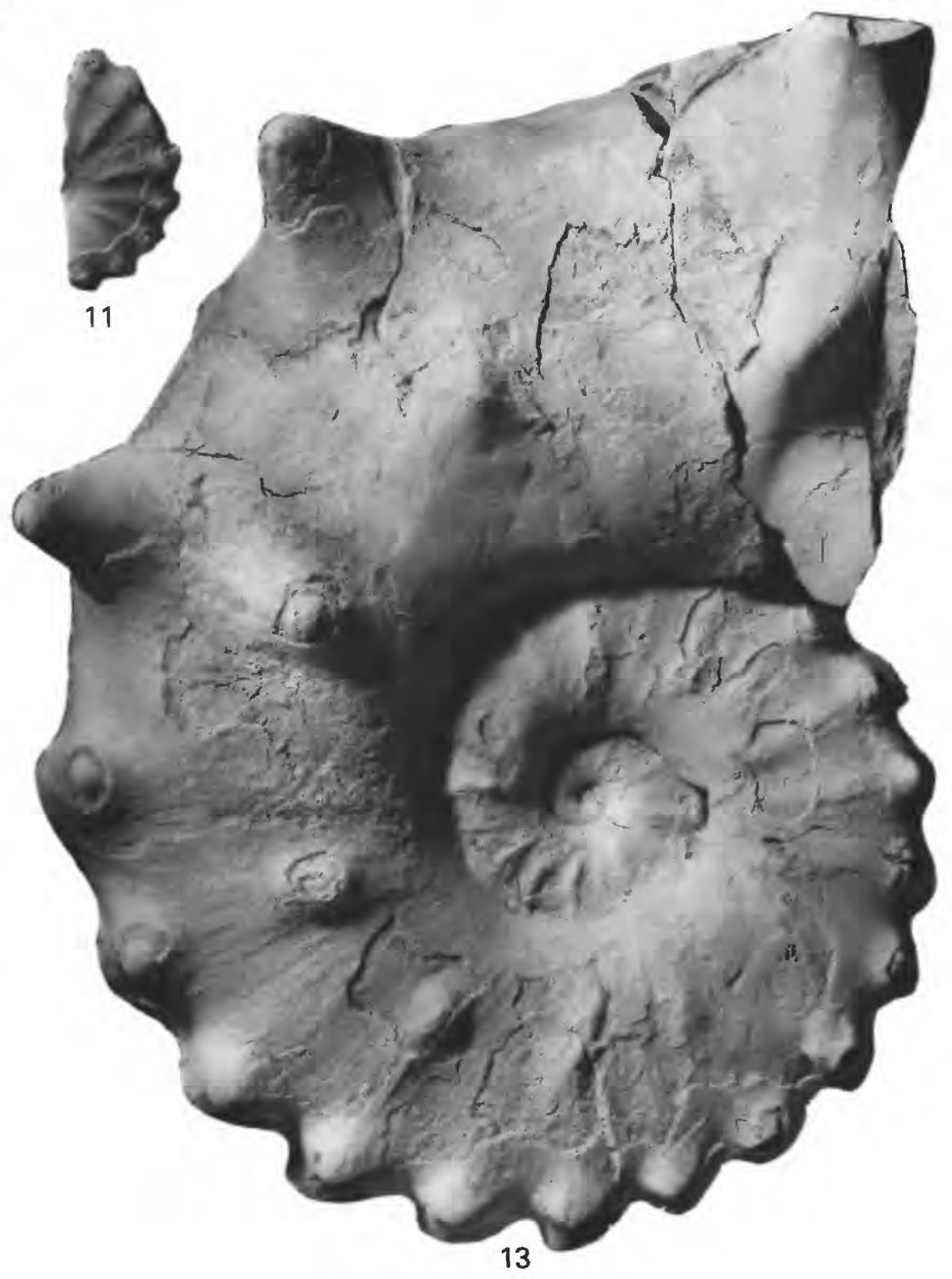

PLESIACANTHOCERAS 


\section{PLATE 12}

[Both figures natural size]

Plesiacanthoceras wyomingense (Reagan) (p. 16).

Rear and side views of hypotype USNM 388165, from the Belle Fourche Shale at USGS Mesozoic locality 22871 (text fig. 1). See plate 11, figures 3-7 for views of the inner whorls. 

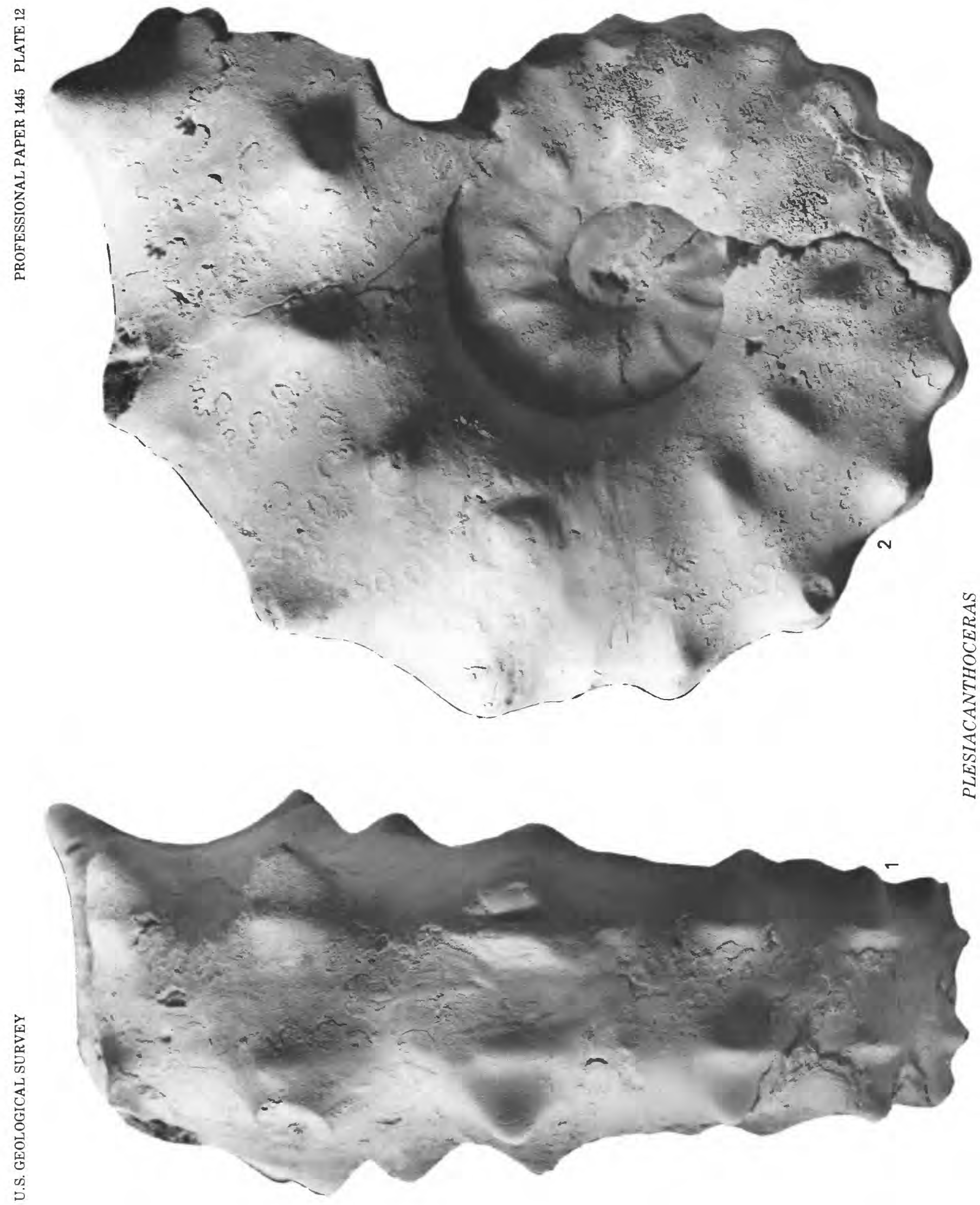
PLATE 13

[All figures natural size. Arrow marks base of body chamber]

Figures 1-6. Plesiacanthoceras wyomingense (Reagan) (p. 16).

From the Belle Fourche Shale at USGS Mesozoic locality 22871 (text fig. 1).

1-3. Rear, side, and front views of hypotype USNM 220381.

4. Rear view of hypotype USNM 388168 showing riblets and spiral ornament on the venter.

5, 6. Side and front views of hypotype USNM 388169. A phragmocone of Moremanoceras is embedded in the body chamber. 

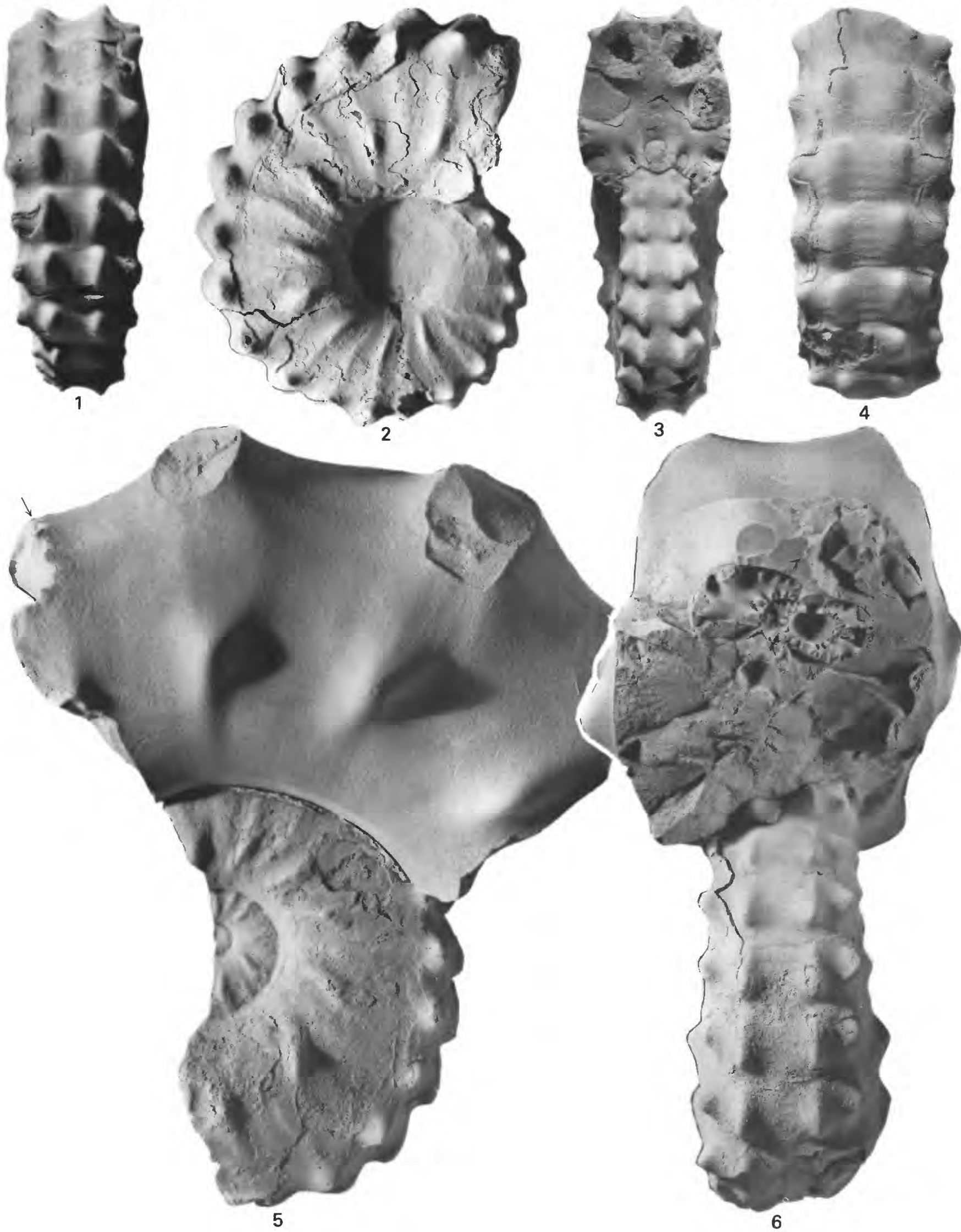